\title{
Avaliação da influência do bruxismo e do gênero na força máxima de mordida dos indivíduos
}

Patricia dos Santos Calderon

Dissertação apresentada à Faculdade de Odontologia de Bauru, da Universidade de São Paulo, como parte dos requisitos para obtenção do título de Mestre em Odontologia, área de Reabilitação Oral.

(Edição Revisada) 


\section{Avaliação da influência do bruxismo e do gênero na força máxima de mordida dos indivíduos}

Patricia dos Santos Calderon

Dissertação apresentada à Faculdade de Odontologia de Bauru, da Universidade de São Paulo, como parte dos requisitos para obtenção do título de Mestre em Odontologia, área de Reabilitação Oral.

(Edição Revisada)

Orientador: Prof. Dr. Paulo César Rodrigues Conti

Bauru, 2005 


\section{CALDERON, PATRÍCIA DOS SANTOS}

C127a Avaliação da influência do bruxismo e do gênero na força máxima de mordida dos indivíduos / Patrícia dos Santos Calderon. Bauru, 2005

xviii, 138 p. : il. ; $30 \mathrm{~cm}$.

Dissertação (Mestrado) -- Faculdade de Odontologia de Bauru. Universidade de São Paulo.

Orientador: Prof. Dr. Paulo César Rodrigues Conti

Autorizo, exclusivamente pra fins acadêmicos e científicos, a reprodução total ou parcial desta tese, por processo fotocopiadores oe/ou meios eletrônicos.

Assinatura do autor:

Data:

Comitê de Ética da FOB-USP

Protocolo n. ${ }^{0:}$ : 146/2002

Data: 13/02/2003 


\section{Patrícia dos Santos Calderon}

14 de fevereiro de 1980

Guarulhos- SP

Filiação

1998-2001

2001-2002

2002-2003

Associações
Nascimento

Regina do Carmo dos Santos Calderon Milton Luis Calderon Tortosa

Curso de Graduação em Odontologia pela Faculdade de Odontologia de AraraquaraUNESP

Curso de Aperfeiçoamento em Reabilitação Oral- Promovido pela Fundação Araraquarense de Ensino e Pesquisa Odontológica (FAEPO)

Estágio de Atualização no curso de Aperfeiçoamento em Reabilitação OralPromovido pela Fundação Araraquarense de Ensino e Pesquisa Odontológica (FAEPO)
SBPqO - Sociedade Brasileira de Pesquisa Odontológica 


\section{"Feliz aquele que transfere o que sabe e aprende o que ensina."}

Cora Coralina 
Àqueles que me concederam a alegria da vida Àqueles que me amaram incondicionalmente Àqueles que acreditaram na minha capacidade Àqueles que concordaram com meus desejos Àqueles que me apoiaram nos meus sonhos Àqueles que são exemplo de amor, união, honestidade e trabalho... E que foram fundamentais, mesmo que à distância, para a concretização deste trabalho...

\section{A VOCÊS, PAI E MÃE, EU DEDICO ESTE TRABALHO.}


Agradecimentos especiais

A Deus, Todo Poderoso, meu guia na Terra...

Por, em momento algum, me deixar fraquejar...

Por todo Seu amor, eterno e interminável...

Que me transmitiu segurança e entusiasmo durante toda esta jornada

Ao meu orientador Prof. Dr. Paulo César Rodrigues Conti.

A você, exemplo de pesquisador e professor, meu respeito.

A você, exemplo profissional e ser humano, minha admiração.

Agradeço pela confiança, incentivo e amizade, que, dia-a-dia, durante esse tempo de convívio e trabalho me fizeram crescer não só como profissional, mas também como pessoa. 
Agradecimentos

Ao meu irmão Leandro, pelo exemplo de profissionalismo e pelos ensinamentos transmitidos, indispensáveis para a concretização deste trabalho.

Ao meu irmão Fábio, pela disposição em me auxiliar, principalmente na parte tecnológica, sempre que necessário.

Ao Prof. Dr. Accácio Lins do Valle pelo apoio durante todo o curso e pela amizade, construída nesse tempo, que torço para que se torne inabalável.

Ao Prof. Dr. Carlos dos Reis Pereira Araújo pelos conhecimentos transmitidos e por ser sempre solícito em me auxiliar nos momentos em que precisei, com muito bom humor, que lhe é peculiar.

Ao Prof. Dr. Luis Fernando Pegoraro, que além de ser um exemplo de trabalho e profissionalismo, contribuiu de forma engrandecedora com sugestões ao projeto de pesquisa, que, posteriormente foram acatadas e, indiscutivelmente, enriquecedoras para este trabalho. 
Ao Prof. Dr. Vinícius Carvalho Porto por ser um exemplo de professor e de ser humano, e por sua paciência e disponibilidade em participar desta pesquisa.

Ao Prof. Dr. José Roberto Pereira Lauris, pelas orientações estatísticas prévias à realização do projeto de pesquisa, e pelo auxílio durante a realização da análise estatística dos dados deste trabalho.

Aos Professores do Departamento de Prótese: Prof. Dr. José Henrique Rubo, Prof. Dr. Paulo Martins Ferreira, Prof. Dr. Gerson Bonfante, Prof. Dr. Milton Carlos Gonçalves Salvador, Prof. Dr. Wellington Cardoso Bonachela, Prof. Dr. Renato de Freitas.

Aos funcionários do Departamento de Prótese: Deborah, Cláudia, Edna, Valquíria e Reivanildo, pela simpatia, atenção e gentileza.

Aos funcionários da Clínica de Pós Graduação: Cleusa e Eduardo, por serem sempre prestativos, auxiliando no bom andamento da clínica.

A todos os funcionários da biblioteca, exemplos de eficiência, organização, dedicação e simpatia. Agradeço pelos conhecimentos transmitidos e pela atenção dispensada. 
A diretora da Faculdade de Odontologia de Bauru, Prof $^{\mathbf{a}}$. Dr ${ }^{\mathbf{a}}$. Maria Fidela de Lima Navarro e ao presidente da Comissão de Pós Graduação, Prof. Dr. José Carlos Pereira por me abrirem as portas de tão reconhecida instituição.

Aos Profs. Drs. Francisco de Assis Mollo Jr. e Paulo Martins Ferreira, pela agradável presença na banca examinadora desta pesquisa, que foi de fundamental importância, por todas as sugestões pertinentes e enriquecedoras realizadas.

Às minhas amigas Mikaela, Thânia, Kátia e Lívia, exemplos de humildade e sensibilidade. Vocês foram indispensáveis em minha vida durante o curso, me ajudaram nas clínicas, seminários e dissertação, sempre me apoiando nos momentos difíceis. Com certeza minha vida sem vocês em Bauru não seria tão feliz. A amizade de vocês espero levar para sempre em meu coração. Amo vocês.

Aos amigos de mestrado Lucas, Estevam, Rodrigo, Filipe, Valdey, Érico, Jonas e Mariana, pela simpatia, incentivo, apoio e amizade.

Aos amigos de doutorado: Leilha, Rafael, Renato, Jefferson, Lula, Paulo Fukashi, Paulo Rossetti, Ayub e Ricardo, pelos conhecimentos difundidos, pela atenção prestada e pela amizade. 
Aos novos mestrandos: Luciana, Romão, Dudu, Thiago, Jefferson, Fernando, Ana Paula, Gabriela e Flora, pela colaboração, pelo bom humor e pela amizade.

A todos os outros os amigos que fiz nesses anos em Bauru, pelo convívio.

À minha amiga Patrícia, pela paciência, pelo convívio diário, pela amizade, pelo apoio, pelos conselhos, pelos incentivos, por ser você, essa pessoa maravilhosa e autêntica.

A cada voluntário que participou dessa pesquisa, pela colaboração, sem a qual a execução desta pesquisa não seria possível.

Ao $\mathbf{C N P q}$, pelo apoio financeiro.

E a todos aqueles que, de alguma forma, contribuíram para a concretização deste trabalho.

MUITO OBRIGADA.

"Deixe algum sinal de alegria, onde passes." (Chico Xavier) 


\section{SUMÁRIO}

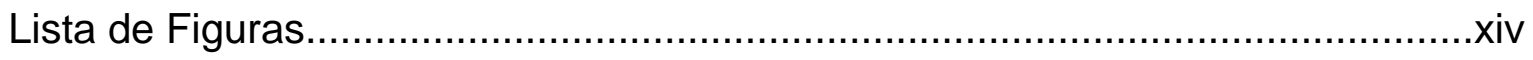

Lista de Tabelas..........................................................................

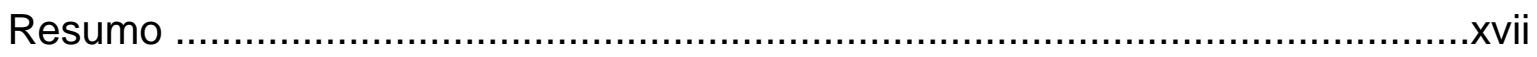

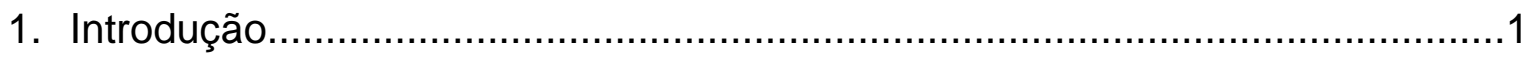

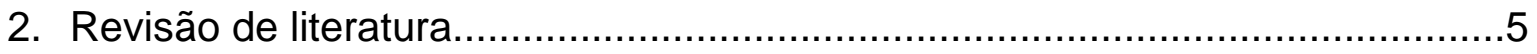

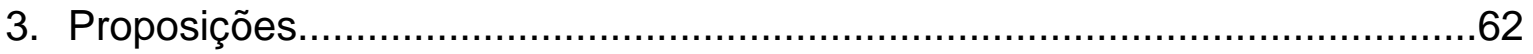

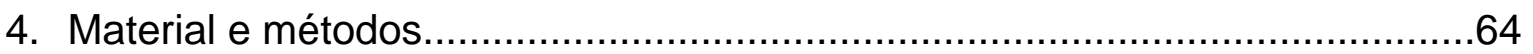

4.1. Comitê de Ética em pesquisa...............................................65

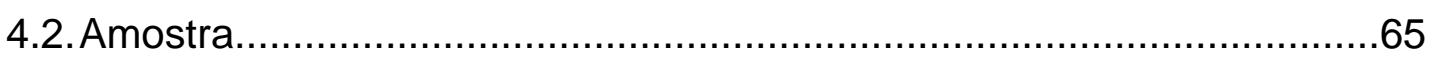

4.3. Critérios de seleção.............................................................67

4.3.1. Exame inicial e questionário de DTM........................................67

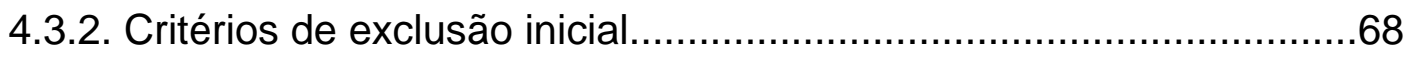

4.3.3. Critérios de inclusão.....................................................69

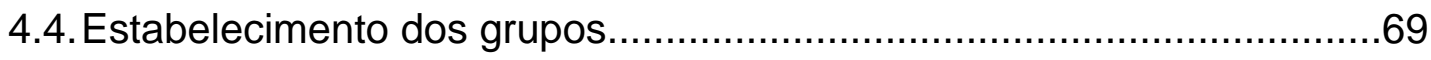

4.5. Registro da força de mordida................................................. 71

4.5.1. Aparelho utilizado............................................................ 71

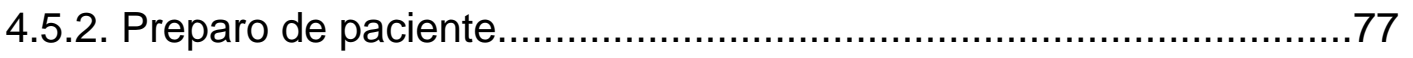

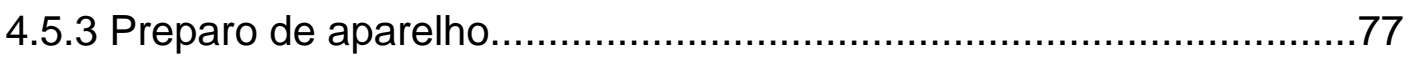

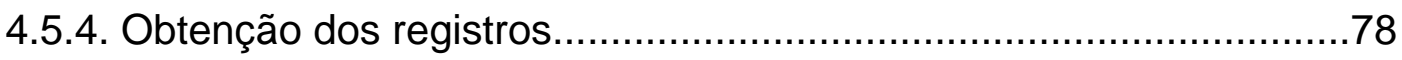

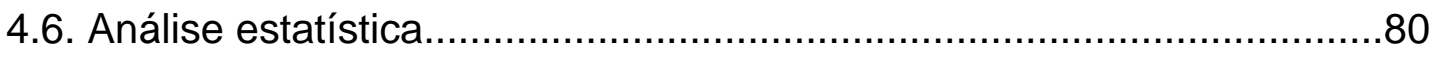

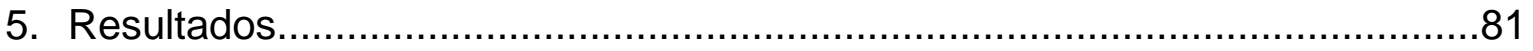


5.1. Força de mordida X Gênero X Bruxismo.........................................82

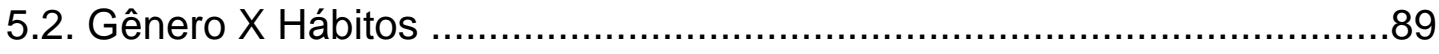

5.3. Concordância inter-examinadores quanto ao exame clínico de

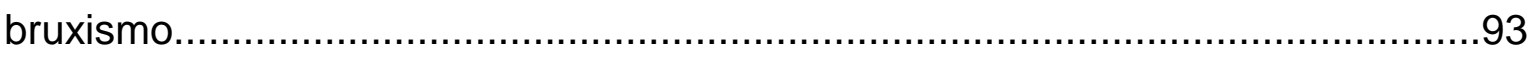

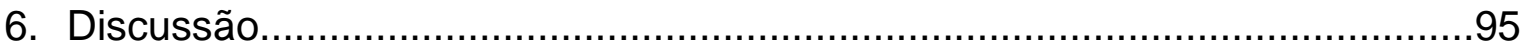

6.1. Metodologia utilizada...............................................................96

6.2. Resultados obtidos.................................................................. 104

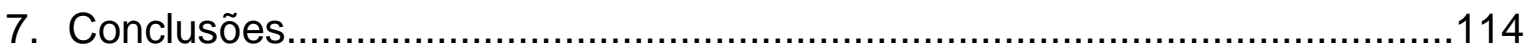

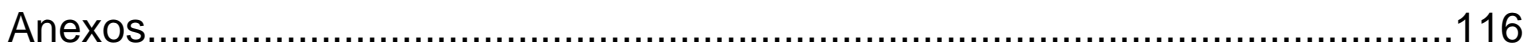

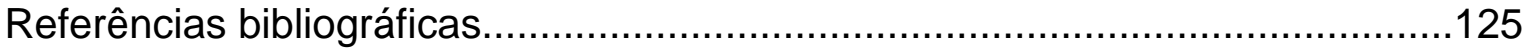

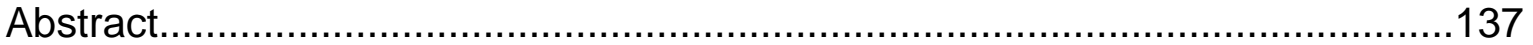




\section{Lista de Figuras}

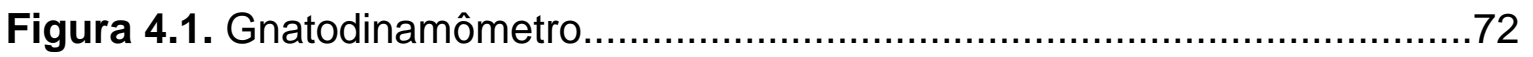

Figura 4.2. Garfo de mordida do gnatodinamômetro...........................................73

Figura 4.3. Corpo do gnatodinamômetro..........................................................73

Figura 4.4. Proteção plástica do garfo de mordida do gnatodinamômetro............74

Figura 4.5. Visão aproximada do mostrador digital de cristal líquido, botões de ajuste e "ajuste do zero". .75

Figura 4.6. Botões de ajuste mostrando as opções utilizadas nessa pesquisa....76

Figura 4.7. Proteção das hastes do gnatodinamômetro, com dedo de luva descartável. .78

Figura 4.8. Mensuração da força de mordida sendo realizada na região de primeiro molar direito

Figura 5.1. Representação gráfica dos valores médios de força máxima de mordida, de acordo com o gênero .83

Figura 5.2. Representação gráfica dos valores médios de força máxima de mordida, de acordo com o grupo.

Figura 5.3. Representação gráfica dos valores médios de força máxima de mordida, de acordo com o sub-grupo. .84

Figura 5.4. Representação gráfica dos valores médios de força máxima de mordida, para o lado direito, de acordo com o grupo.

Figura 5.5. Representação gráfica dos valores médios de força máxima de mordida, para o lado esquerdo, de acordo com o grupo. .89 
Figura 5.6. Porcentagem de indivíduos, portadores ou não de hábitos parafuncionais, do gênero feminino. 92

Figura 5.7. Porcentagem de indivíduos, portadores ou não de hábitos parafuncionais, do gênero masculino. .92

Figura 5.8. Porcentagem de concordância inter-examinadores para diagnóstico clínico de bruxismo. .94

Figura 5.9. Valores de Kappa encontrados neste trabalho .94 


\section{Lista de Tabelas}

Tabela 4.1. Médias das idades dos participantes dessa pesquisa (em

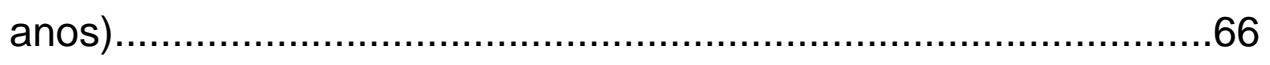

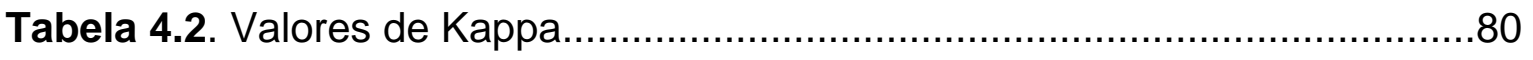

Tabela 5.1. Médias dos valores de força máxima de mordida nos diferentes grupos e gêneros (em KgF), e respectivos desvios- padrão...... .82

Tabela 5.2. Médias e desvios padrão, aproximados, dos valores de força máxima de mordida, do lado direito, nos diferentes grupos (valores em $\mathrm{KgF})$ .86

Tabela 5.3. Médias e desvios padrão, aproximados, dos valores de força máxima de mordida, do lado esquerdo, nos diferentes grupos (valores em $\mathrm{KgF})$ .88

Tabela 5.4. Porcentagem de indivíduos portadores de hábitos, para os gêneros feminino e masculino 91 
RESUMO 


\section{RESUMO}

O objetivo desta pesquisa foi avaliar a influência do gênero e do bruxismo na força máxima de mordida. Além disso, a concordância inter-examinadores para o exame físico de bruxismo, foi estudada. Para isso, foram selecionados 120 indivíduos, de ambos os gêneros, portadores ou não de bruxismo, com idade média de 24,06 anos. Para o estabelecimento dos grupos, todos os indivíduos foram submetidos a critérios de exclusão e inclusão, e a exame físico específico para bruxismo (realizado por três examinadores). Após isso, a força máxima de mordida de cada indivíduo foi mensurada com o auxílio de um gnatodinamômetro na região de primeiro molar, três vezes de cada lado, em duas sessões separadas por dez dias, em média. O maior valor de força, dentre os seis encontrados para cada lado, foi utilizado como resultado. Os dados, então, foram analisados estatisticamente através de análise de variância a dois critérios, com nível de significância de 5\%. Para a análise da concordância inter-examinadores utilizou-se o teste estatístico de Kappa. Os valores de força máxima de mordida, independentemente do grupo, foram significantemente maiores para o gênero masculino $(p=0,00)$. Por outro lado, não foi observada, independentemente do gênero, diferença significante entre os valores de força máxima de mordida para os indivíduos portadores ou não de bruxismo $(p=0,25)$. Ainda, a concordância inter-examinadores para $o$ exame físico de bruxismo foi considerada ótima entre os 3 examinadores dessa pesquisa. Baseado nos resultados obtidos, conclui-se que a força de mordida não deve ser usada como parâmetro para detecção de bruxômanos. 
1. INTRODUÇÃO 


\section{INTRODUÇÃO}

As forças oriundas do sistema mastigatório são o resultado da coordenação entre as funções muscular, nervosa, óssea e dental. A mensuração de tais forças exerce papel importante no diagnóstico dos distúrbios que afetam o sistema estomatognático (PELIZZER e MUENCH, 1997) ${ }^{48}$.

Segundo HATCH et al. ${ }^{19}$, em 2000, a força de mordida, assim como o número de unidades dentais, são fatores determinantes na performance mastigatória, sugerindo que a manutenção desses fatores pode ser de grande valia para a função.

Entende-se por força máxima de mordida, a capacidade dos músculos elevadores da mandíbula de exercer um esforço máximo dos dentes inferiores contra os superiores em condições favoráveis à saúde de suas estruturas ${ }^{48}$.

A força da musculatura mandibular determina a quantidade de força existente para cortar ou triturar os alimentos e vários métodos são usados para estudar clínica e fisiologicamente as características dos músculos envolvidos nesse processo ${ }^{51}$. Dentre esses vários métodos de mensuração desenvolvidos para a avaliação da força de mordida estão os gnatodinamômetros e os transdutores de força, entre outros ${ }^{47}$.

Atualmente, todos os instrumentos de mensuração de força de mordida têm sua função baseada na ação de uma resistência elétrica. Porém, dimensões e formas de tais aparelhos, muitas vezes, podem limitar seu uso em determinadas regiões da cavidade oral ${ }^{13}$. Além disso, segundo TORTOPIDIS et al. ${ }^{58}$, em 1998, a veracidade dos resultados dos valores de força de mordida depende de alguns 
fatores, como o tipo e o conforto do transdutor, bem como a posição do mesmo no arco dental.

Ainda, TORTOPIDIS et al. ${ }^{58}$, em 1998 , citaram fatores que podem influenciar os valores de força de mordida relacionado ao indivíduo, como força dos músculos elevadores da mandíbula, estado da dentição e limiar de dor (sensibilidade muscular, dental ou articular).

Além disso, o número de dentes presentes demonstrou ser um fator importante na força de mordida, segundo AGERBERG, em 1988.

HELKIMO, CARLSSON e HELKIMO ${ }^{22}$, em 1976, encontraram idade e gênero como variáveis que podem influenciar a força máxima de mordida.

A participação de hábitos parafuncionais, como ranger e apertar os dentes, ainda não está bem elucidada nesse cenário.

LINDQVIST e RINGQVIST ${ }^{34}$ definiram o bruxismo como o simples ato de ranger e/ou apertar os dentes sem um propósito funcional e relataram ainda existir um aumento da força de mordida exercida entre os dentes superiores e inferiores durante esse ato. A Academia Américana de Dor Orofacial - AADO ${ }^{3}$, em 1996, definiu o bruxismo como uma atividade parafuncional diurna ou noturna, que inclui apertamento ou ranger dos dentes. Por outro lado, a Associação Americana de Desordens do Sono - $\mathrm{AADS}^{4}$ classificou, em 1997, o bruxismo como uma parassônia, ou seja, uma desordem de movimentos estereotipados e periódicos do sistema mastigatório que envolve apertamento ou ranger de dentes durante o sono, excluindo, portanto, atividades parafuncionais diurnas (em vigília). Foi afirmado, também, por LAVIGNE, ROMPRÉ e MONTPLAISIR ${ }^{31}$, em 1996, que o diagnóstico de bruxismo é baseado no relato de apertar ou ranger os dentes, 
associado a, no mínimo, um dos seguintes sinais: facetas de desgaste, sons noturnos associados a ranger de dentes e desconforto muscular.

Tanto os estudos de levantamento epidemiológico, realizados em população de estudantes (GLAROS, 1981) ${ }^{16}$, quanto na população em geral

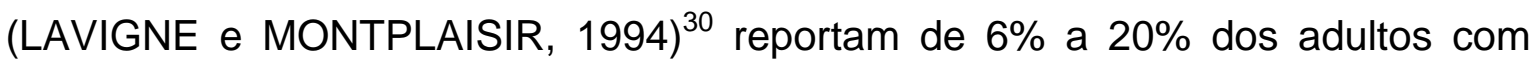
apertamento ou ranger de dentes, sendo essa uma proporção alta para um achado de diagnóstico ainda controvertido. Além disso, em crianças de 11 anos de idade, MIGRAINE et al. $^{39}$, em 1996 observaram a prevalência de aproximadamente $14 \%$ de bruxômanos, e WILDMALM et al. ${ }^{62}$, em 1995, relataram a prevalência de $20 \%$ de bruxômanos entre crianças brancas e negras de 4 a 6 anos de idade. Mais tarde, em 1997, LOBBEZOO et al. ${ }^{35}$ relatam que a incidência de bruxismo diminui com a idade. Com relação ao gênero, o apertamento parece apresentar-se $22 \%$ mais freqüente nas mulheres, muito embora esta mesma predileção não tenha sido verificada pelo hábito de rangimento ${ }^{17}$.

Pela leitura de vasta literatura surgiu a dúvida da possibilidade de pacientes portadores de bruxismo (que realizam apertamento e rangem os dentes) terem uma alteração em sua força máxima de mordida, uma vez que esses pacientes executam, inconscientemente, forças excessivas sobre seus elementos dentários, o que pode causar uma alteração muscular. Dessa maneira, há a hipótese de que os indivíduos portadores de bruxismo apresentem valores mais altos de força máxima de mordida.

Além disso, o gênero também é ainda motivo de controvérsia em relação à força máxima de mordida. 
2. REVISÃO DE LITERATURA 


\section{REVISÃO DE LITERATURA}

AHLGREN et al. ${ }^{2}$, em 1969 analisaram a conexão entre bruxismo e hipertrofia do músculo masséter através de achados clínicos e laboratoriais encontrados em 3 meninos de 16 a 18 anos, que apresentavam hipertrofia bilateral (2), ou unilateral esquerda (1) do músculo masséter. No exame clínico foram encontrados: morfologia e função oclusal normais, ATM clinicamente normais e ausência de sintomas de doença periodontal. No exame radiográfico a sialografia e a radiografia de ATM mostraram-se normais, e a cefalometria mostrou valores de ângulo goniano menores que o normal. No exame eletromiográfico (EMG), na posição de máxima tensão muscular, os valores encontrados foram 2 vezes maiores que os encontrados em indivíduos normais da mesma idade. A força de mordida (testada com o auxílio de um gnatodinamômetro) mensurada nos dentes anteriores revelou um valor 2 vezes maior que o encontrado em indivíduos normais da mesma idade. $\mathrm{E}$, finalmente, o exame microscópico revelou que a hipertrofia dos músculos leva a um aumento do diâmetro da fibra muscular para, aproximadamente, $50 \mu \mathrm{m}$, o que é mais que 2 vezes o normal, levando os autores a concluir que esse aumento de diâmetro ocorre devido ao aumento da força muscular, que foi revelado nos testes de EMG e de força de mordida. Ainda, que não se conhece a causa da hipertrofia, mas o bruxismo, através do apertamento e ranger dos dentes, leva ao desenvolvimento de um músculo exercitado, que pode se apresentar hipertrófico, e de facetas de desgaste dentário. 
Em 1970, LINDERHOLM e WENNSTROM ${ }^{32}$ estudaram a relação entre a força de mordida, força muscular e estrutura corporal. Para isso foram selecionados 72 estudantes saudáveis, 58 homens e 14 mulheres, com idade entre 18 e 31 anos, que foram submetidos a exames clínico e radiográfico. Nessa etapa eram excluídos aqueles indivíduos que apresentassem patologias articulares ou periodontais. Após isso, os indivíduos realizaram testes no equipamento de medir força de mordida, para se adaptar ao mesmo, então foi iniciada a medição de força de mordida por um único examinador com o auxílio de um dinamômetro de força desenvolvido para esse estudo. As áreas selecionadas para a realização dos testes foram de $1^{\circ}$ molar e prés-molares dos lados esquerdo e direito, sendo que em alguns indivíduos a força dos incisivos centrais também foi medida. Foram realizadas 3 medidas para cada região, sendo o maior valor considerado como força máxima de mordida da região. Após isso foram realizadas medições da força de pegada, da força de flexão do cotovelo, tronco e pescoço, com um dinamômetro semelhante ao utilizado para medir a força de mordida. Nesse teste 31 homens e 14 mulheres foram examinados por um examinador, e o restante dos indivíduos, por outro. Os resultados demonstraram que a média da força de mordida dos indivíduos do gênero masculino foi numericamente maior que a do gênero feminino, porém tal diferença não foi estatisticamente significante, também não houve diferença estatisticamente significante entre ambos os lados em um mesmo indivíduo. Nos exames da força dos músculos do braço, pescoço e tronco, os homens também tiveram maior valor numérico, que foi estatisticamente significante. Porém, não houve correlação 
estatisticamente significante entre força de mordida e força dos demais músculos corporais, peso, altura e dimensões corporais.

Um ano depois, em 1971, LINDERHOLM et al. ${ }^{33}$, voltaram a estudar a relação entre a força de mordida, força muscular e estrutura corporal, porém desta vez em crianças. Para esse novo estudo, foram avaliadas 100 crianças de 12 anos de idade (49 meninos e 51 meninas). Dessas, apenas 79 crianças (37 meninos e 42 meninas), foram selecionadas para essa pesquisa, as demais foram excluídas por doença ou por falta de algum $1^{\circ}$ molar. A força máxima de mordida foi medida na região de $1^{\circ}$ molar de ambos os lados, com o mesmo dinamômetro utilizado na pesquisa no ano anterior. Após os indivíduos se adaptarem ao aparelho, foi medida a força de mordida 3 vezes de cada lado, e o maior valor foi utilizado como força máxima para cada lado. Todos os exames foram realizados por um mesmo examinador. A força de pegada e de flexão do cotovelo também foram medidas com o mesmo aparelho utilizado no ano anterior. A medição também foi realizada por 3 vezes, só do lado direito, e o maior valor foi utilizado como o de força máxima. Existiu uma correlação positiva entre a força máxima de mordida, dos lados esquerdo e direito. Não houve diferença estatisticamente significante entre meninos e meninas no que diz respeito à força de mordida, dimensões corporais e força muscular dos músculos do braço. Houve uma pequena correlação entre a força de mordida e as outras variáveis mencionadas, o que não havia acontecido no estudo dos adultos, e levou os autores a concluírem que a utilização dos músculos mastigatórios é importante para o desenvolvimento da força máxima de mordida. 
MOLIN ${ }^{42}$, em 1972 estudou os níveis, as variações, as inter e intra correlações da força de mordida voluntária (em várias intensidades), produzida durante protrusão, retrusão e lateralidade, entre pacientes com e sem manifestações de DTM. Para tal, selecionou 31 mulheres com idades entre 16 e 45 anos (18,3 anos, em média), todas com manifestações de DTM, sendo 30 com manifestações unilaterais e 1 com manifestações bilaterais, formando assim o grupo experimental. Além disso, selecionou 30 mulheres, entre 18 e 28 anos $(22,1$ anos, em média), sem alterações oclusais ou doenças periodontais que receberam pagamento pela sua participação, e formaram o grupo controle. 0 medidor de força de mordida utilizado nesse estudo foi desenvolvido seguindo os princípios descritos por LINDERHOLM E WENNSTROM ${ }^{32}$, em 1970. Antes da realização dos testes, as participantes foram informadas do objetivo da pesquisa e tiveram instruções e a oportunidade de testar o equipamento para se adaptarem. Durante as mensurações, as participantes permaneceram sentadas e sem apoiar a cabeça. A região escolhida para realização dos testes foi a região de prés-molares. Durante os testes, elas foram instruídas para a realização de força de mordida conforme uma escala de intensidades (1-muito fraca, 2-fraca, 3nem fraca nem forte, 4-forte, 5-máxima), e tiveram que manter essa força durante 3 segundos, com intervalo de 10 segundos entre cada esforço. Foram realizados 4 esforços para cada intensidade para cada lado, totalizando 40 esforços, e apenas os 2 maiores valores foram levados em consideração na análise estatística. Foi percebido que o valor da força de mordida aumenta conforme a intensidade executada através da escala. Para as participantes do grupo controle, não foi encontrada diferença estatisticamente significante para os valores de força 
de mordida entre os lados direito e esquerdo. Já no grupo experimental, essa comparação foi feita entre o lado afetado e o não afetado, e os resultados demonstraram que nas intensidades de 1 a 4, o lado não afetado teve valores um pouco maiores que o afetado, porém quando se comparou a força máxima de mordida, o maior valor foi obtido pelo lado afetado, mas, no entanto, não houve diferença estatisticamente significante entre lados afetado e não afetado, para todas intensidades de força. Na comparação entre grupos, encontrou-se que para a intensidade 1 da escala, os 2 grupos realizaram a mesma força, para as intensidades de 2 a 4 , as portadoras de DTM realizaram força com metade do valor das realizadas pelo grupo controle, já para força máxima, o valor obtido para as portadoras de DTM foi dois terços menor que o obtido pelo grupo controle. Já quando o autor comparou os esforços verticais aos horizontais (protrusão, retrusão e lateralidade), percebeu que os esforços verticais excedem os horizontais, em todos os aspectos. Mas, apesar disso, o autor concluiu que, essas forças horizontais, apesar de terem valores reduzidos, são importantes durante a função mastigatória, pois reduzem a carga necessária para mastigar alimentos duros e consistentes.

LINDQVIST e RINGQVIST ${ }^{34}$, em 1973, comparam a força de mordida de crianças com e sem bruxismo com o intuito de avaliarem se o bruxismo pode causar alterações na força de mordida e se o grau de abrasão dos dentes afeta a força de mordida. Para esse estudo, foram selecionadas 96 crianças de 12 anos de idades (50 garotos e 46 garotas). Facetas de desgaste coincidentes foram usadas como critério de inclusão para o grupo experimental. Foram consideradas 
as facetas em esmalte durante o movimento de lateralidades, ou facetas de dentina durante protrusão. As crianças com bruxismo foram divididas em 3 grupos: o grupo 1 era composto por crianças que apresentavam facetas de desgaste em dentina em topo-a-topo; o grupo 2 formou-se por crianças com facetas de desgaste em esmalte em lateralidade; no grupo 3 crianças que possuíam, simultaneamente, os dois tipos de facetas de desgaste. As facetas de desgaste foram encontradas em 30 garotos e 21 garotas, sendo que desses, 6 garotos e 8 garotas rangiam os dentes à noite, como foi relatado por seus pais. Os 20 garotos e 25 garotas sem facetas de bruxismo formaram o grupo controle. Nenhuma da 96 crianças apresentava dor nos músculos mandibulares ou ATM. A força de mordida foi registrada usando o mesmo método que foi utilizado por LINDERHOLM et al. ${ }^{33}$, em 1971. Nesse caso, a força foi medida na região de $1^{\circ}$ molar, antes do registro, as crianças tiveram a oportunidade de se familiarizarem com o aparelho. Depois disso, foi solicitado verbalmente que as crianças realizassem forças em 4 intensidades (1-muito fraca, 2-fraca, 3-forte, 4- máxima). Três séries de registros foram realizadas para cada lado, com pausa de 15 segundos entre cada série. Porém, como não houve diferença estatisticamente significante entre os valores dos lados direito e esquerdo, a média dos 6 valores obtidos para cada intensidade de força foi utilizada como resultado, e o maior de todos os valores foi utilizado como força máxima de mordida. Os resultados demonstraram que, para o nível 1 de intensidade de força, não houve diferença estatisticamente significante entre os grupos controle e experimental, porém houve diferença estatisticamente significante, com $p<0,01$, entre os garotos e as garotas do grupo experimental e o mesmo aconteceu no grupo controle (nesse 
caso com $p<0,05)$, e em ambos os casos o maior valor encontrado foi do gênero masculino. A força de mordida dos garotos com facetas de desgaste em dentina apenas (grupo 1), foi significantemente maior (com $p<0,05)$ que a dos garotos com outros tipos de facetas (grupos 2 e 3 ). Fora isso, nenhuma outra diferença estatisticamente significante foi encontrada dentro do grupo experimental, nem entre gêneros e nem entre grupos quando da combinação dos valores dos gêneros. Portanto, a diferença da força máxima de mordida não foi estatisticamente significante entre bruxômanos e não bruxômanos, nem entre garotos e garotas. Com esse estudo, os autores puderam concluir que não há evidências de que o bruxismo excêntrico afete a força de mordida.

Um estudo clínico longitudinal sobre a força de mordida em pacientes tratados por motivo de DTM, foi realizado em 1975 por HELKIMO, CARLSSON e CARMELI $^{21}$. Os autores selecionaram 30 indivíduos (24 mulheres e 6 homens), com idades entre 17 e 70 anos (com média de 28 anos), examinados e tratados por DTM, sem doenças periodontais, cáries ou restaurações de amálgama extensas e com molares ocluíndo bilateralmente, para formarem o grupo experimental, e mais 26 indivíduos (16 homens e 10 mulheres), com idades entre 18 e 32 anos (23 anos em média), sem nenhum sinal ou sintoma de DTM, para o grupo controle. Todos os indivíduos foram examinados quanto ao tipo de mordida, grau de abrasão, abertura máxima, dor na ATM, dor nos movimentos mandibulares e sensibilidade à palpação dos músculos mastigatórios e ATM. A força de mordida foi mensurada entre os primeiros molares e incisivos centrais, com um aparelho especialmente desenvolvido para essa pesquisa, nas seguintes 
intensidades: 1-muito fraca, 2-fraca, 3-nem fraca nem forte, 4-forte, 5-máxima. Com o mesmo aparelho foi medida também a força de pegada dos dedos da mão. Para cada intensidade de força foi realizada a seguinte seqüência: força dos dedos, molares direitos, incisivos, molares esquerdos e força dos dedos. Os indivíduos do grupo controle foram examinados em duas ocasiões, com intervalos entre 1 dia e 5 semanas (média de 1 semana). Os pacientes foram examinados em 3 ocasiões: antes do início do tratamento; quando os sintomas começaram a diminuir ( 3 semanas em média) e no fim do tratamento ( 3 meses em média). Na maioria dos pacientes os sintomas eram unilaterais, e eles foram tratados com aconselhamento, placa oclusal, fisioterapia e farmacoterapia. Nos resultados foi observado que a força de mordida dos homens do grupo controle foi numericamente maior que a das mulheres do mesmo grupo, porém isso não representou diferença estatisticamente significante. Porém os limites dos movimentos mandibulares foi maior $($ com $p<0,01)$ para os homens. No entanto, para as outras variáveis, nenhuma diferença estatisticamente significante foi encontrada no grupo controle. Já no grupo experimental a força de mordida dos homens foi numericamente maior que a das mulheres, porém isso representou diferença estatisticamente significante apenas em determinado número de casos (para $p<0,05,6$ casos em 30). Comparando o lado afetado com o não afetado dos 23 pacientes que apresentavam sintomas unilaterais, não foi encontrada diferença significante, numericamente os valores eram maiores no lado não afetado. Na maioria das vezes, após tratamento, essa diferença aumentou ainda mais. Com isso os autores concluíram que com a DTM o valor da força de 
mordida diminui, porém com o alívio dos sintomas durante o tratamento, a mesma parece aumentar.

Em 1976, HELKIMO, CARLSSON e HELKIMO ${ }^{22}$ elaboraram um método simples de mensurar força de mordida e elucidaram a relação entre força de mordida e gênero, idade, estado da dentição, estado funcional do sistema mastigatório e força de pega dos dedos. A força de mordida foi aferida em 125 indivíduos (68 mulheres e 57 homens), com idade entre 15 e 65 anos (32,6 anos, em média), através de aparelhos ligados a garfos metálicos, onde os indivíduos realizavam o esforço. O estado da dentição e do sistema mastigatório foram examinados segundo o índice de Helkimo. Um dos aparelhos utilizados para medir a força de mordida registrava esforços de até $25 \mathrm{Kg}$ e o outro, de até 100 Kg. A força máxima de mordida foi medida nas regiões de primeiros molares e incisivos, e quando os molares estavam ausentes, a região de prés-molares ou caninos era utilizada. O mesmo aparelho foi utilizado para medir a força dos dedos da mão. A série de medições era repetida após 2 minutos, e o maior valor obtido era utilizado como resultado. Para os indivíduos com dentição natural foi utilizado o aparelho de $100 \mathrm{Kg}$, e para os portadores de próteses, o de $25 \mathrm{Kg}$, além disso, 26 indivíduos foram examinados com ambos os garfos, afim de comparar a precisão dos mesmos. Os resultados foram analisados por métodos estatísticos convencionais, teste $\mathrm{T}$ de Student e testes de Mann-Whitney. Comparando os registros, para o mesmo indivíduo, com os dois aparelhos, não se encontrou diferença significante. Ainda, não foram encontradas diferenças de força entre os lados direito ou esquerdo do mesmo indivíduo. Porém, os valores 
de força da mão direita foram significantemente maiores que os da mão esquerda $(p<0,05)$. Os valores de força encontrados para os incisivos foram significantemente menores que os dos molares. Os valores de força dos dedos e de mordida foram significantemente maiores para os homens que para as mulheres. Além disso, encontrou-se que a força de mordida diminui com a idade, especialmente nas mulheres. Os autores ainda relataram que a força de mordida dos portadores de próteses totais foi substancialmente menor que a das pessoas com dentição natural.

HELKIMO e INGERVALL ${ }^{20}$, em 1978 estudaram a possibilidade de haver alguma associação entre força de mordida, estado funcional do sistema mastigatório, desgaste dentário e parafunções em 100 estudantes do gênero masculino com idades entre 21 e 36 anos, e média de 24,8 anos. A história dos indivíduos foi relatada através de um questionário onde os indivíduos eram questionados sobre sintomas de disfunções do sistema mastigatório (estalido, crepitação, fadiga ou rigidez dos músculos mastigatórios, dificuldade de abertura bucal, dor nos movimentos mandibulares, apertamento ou ranger noturno ou diurno, travamento mandibular, cefaléias ocasionais ou semanais e outras parafunções como morder a língua, os lábios a bochecha ou objetos) e sobre saúde geral (sintomas nas articulações ou músculos, em geral e alterações gerais de saúde). Pelas respostas ao questionário, os indivíduos eram agrupados segundo o índice anamnésico de disfunção de Helkimo ( $0=$ sem sintomas, I= sintomas moderados, $\|=$ sintomas severos). $\mathrm{O}$ exame clínico avaliou o limite dos movimentos mandibulares, a função das ATM, dor muscular ou articular à 
palpação e dor nos movimentos mandibulares e agrupou os indivíduos segundo o índice clínico de disfunção de Helkimo. O desgaste dentário foi avaliado da seguinte maneira: 1= sem desgaste ou desgaste mínimo, 2= desgaste apenas em esmalte, $3=$ desgaste em dentina em apenas 1 dente, 4= desgaste em dentina em diversos dentes e $5=$ desgaste extenso, mais de metade da coroa. Após isso a força de mordida e dos dedos foram mensuradas com o mesmo aparelho utilizado por HELKIMO, CARLSSON e CARMELI ${ }^{21}$, em 1975. A força de mordida foi medida entre os primeiros molares e os incisivos e a força dos dedos, entre o polegar e o indicador, de ambos os lados. Foi medida a força máxima de mordida e a força de mastigação (pacientes eram instruídos para realizar a força equivalente à força utilizada para morder e mastigar cenoura crua). Os testes estatísticos utilizados foram Qui-quadrado, T de Student, Mann-Whitney e correlação de Spearman. Os resultados não demonstraram diferenças significantes entre a força de mordida ou de mastigação para os lados direito e esquerdo de um mesmo indivíduo, porém a força de pega da mão direita foi significantemente maior que a da mão esquerda, resultando na não correlação entre força dos dedos, força de mordida ou de mastigação. Os indivíduos conscientes de ranger noturno apresentaram os maiores valores de forças de mastigação e força de mordida nos incisivos. Aqueles que reportaram morder lábios, língua, bochecha ou outros objetos, tiveram maior força de mordida nos molares e incisivos que os indivíduos sem hábitos. Os participantes portadores de estalidos ou desvios nos movimentos mandibulares tiveram força de mordida menor que os outros participantes. Aqueles com sensibilidade muscular à palpação tiveram maior força de mastigação nos incisivos que os que não 
apresentaram sensibilidade à palpação. Houve correlação positiva entre força de mordida e desgaste dentário e entre força de mastigação dos incisivos e desgaste dentário. Por esses resultados os autores concluíram que homens com hábitos de apertar ou ranger tiveram maior força de mordida e de mastigação, nos incisivos, mas não nos molares, devido ao fato que os hábitos são normalmente realizados em posição excêntricas, que pode levar ao treino dos músculos na posição protruída, que acontece quando se mede a força nos incisivos, em contraste com a posição mais cêntrica da mandíbula, que acontece durante a mensuração da força dos molares.

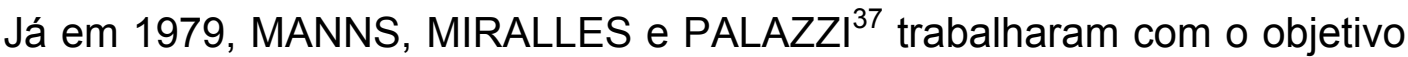
de estudar as relações entre eletromiografia (EMG), força e alongamento muscular durante contrações isométricas do músculo masseter, com abertura bucal de $7 \mathrm{~mm}$ até quase a abertura total (medida da borda distal do canino superior até o inferior). Para isso 4 homens e 4 mulheres, com média de idades de 25 anos (entre 19 e 32 anos), com oclusão normal e sem DTM, foram selecionados. A EMG foi realizada através de eletrodos superficialmente posicionados no masséter, e a força de mordida foi registrada através de um gnatodinamômetro, na região entre caninos e prés-molares, em diferentes aberturas bucais. Duas séries de registros foram realizadas: 1- avaliando a atividade eletromiográfica do masséter com força de mordida constante (10 e 20 $\mathrm{Kg})$, em diferentes aberturas bucais $(7,10,15,20,25,30,35,40 \mathrm{~mm}), 2-$ avaliando a força de mordida com constante atividade EMG do masséter (20 e $40 \%$ da atividade EMG máxima obtida), com diferentes aberturas bucais $(7,10$, 
$15,20,25,30,35,40 \mathrm{~mm}$ ). Os resultados demonstraram que maior força (10 ou $20 \mathrm{Kg}$ ), leva a maior atividade EMG. Além disso, altos valores de atividade EMG foram encontradas com abertura de $7 \mathrm{~mm}$, o menor valor foi encontrado com abertura de 15 e $20 \mathrm{~mm}$, porém a maior atividade encontrou-se aos $40 \mathrm{~mm}$ de abertura bucal. O melhor alongamento muscular, ou seja, a melhor abertura bucal quando há a menor atividade EMG para força constante foi determinada para cada indivíduo, sendo em média $18 \mathrm{~mm}$. A força de mordida também varia proporcionalmente com a atividade eletromiográfica (20 ou 40\%). Ainda, a menor força foi desenvolvida com $7 \mathrm{~mm}$ de abertura, crescendo gradualmente até 15 a 20mm, e diminuindo novamente até a abertura máxima. O melhor alongamento muscular, ou seja, a melhor abertura bucal quando há a maior força, com atividade EMG constante, foi determinado para cada indivíduo, sendo em média 18mm. Por outro lado, a abertura bucal considerada a mais confortável foi próxima a $10 \mathrm{~mm}$, ou seja, abaixo do grau de ótima eficiência muscular, onde é desenvolvida a maior força com a menor atividade EMG (18mm, em média).

Em 1984, CLARK, BEEMSTERBOER e JACOBSEN ${ }^{9}$ estudaram o efeito de sustentar a mordida por determinado tempo, sobre a força de mordida de pacientes com dor miofascial. Para isso, pacientes com e sem dor miofascial foram selecionados e tiveram sua força máxima de mordida medida antes e depois de sustentar a mordida. O grupo controle era composto por 28 indivíduos, sendo 12 do gênero masculino e 16 do feminino, com idades entre 19 e 36 anos e uma média de 25,3 anos, com função normal da ATM e sem história de problemas prévios envolvendo a articulação, além disso, eram adultos saudáveis, 
sem dores agudas de origem dental, e que não utilizavam nenhum tipo de medicamento. Para o grupo experimental, 20 pacientes foram selecionados, sendo 4 homens e 16 mulheres, com idades entre 20 e 40 anos e média de 32, 4 anos, com sintomatologia dolorosa que aumenta com a função (aqui considerado como característica de dor miofascial envolvendo a musculatura elevadora da mandíbula). A origem muscular dessa dor foi confirmada com palpação muscular. Não foram selecionados pacientes que apresentassem sintomas de desordens de origem intracapsular, bem como pacientes com desvio significante durante a abertura. A força de mordida foi monitorada através de um transdutor intraoral de força. A região selecionada para tal foi de $2^{\circ}$ pré-molar a $1^{\circ}$ molar. Após instruções e familiarização com o aparelho, cada indivíduo realizou a força máxima de mordida, dessa força foi calculado o valor de $30 \%$, então os indivíduos foram instruídos para executar essa força (controlada pelo visor do aparelho), e mantê-la o tempo que tolerassem sem sentir dor. Três 3 segundos após os indivíduos cessarem esse esforço, eles executaram novamente a força máxima de mordida. Após 3 meses, 22 indivíduos do grupo controle foram novamente chamados para mensuração de sua força máxima de mordida. Nos resultados foi aplicada ANOVA. Houve diferença estatisticamente significante entre o grupo controle e experimental, com $p<0,001$, sendo que o grupo controle executou força máxima 4 vezes maior que o experimental, tanto antes quanto depois de manutenção do esforço. Além disso, a análise dos resultados demonstrou que o grupo controle teve ligeiro aumento na força máxima de mordida depois do esforço (de $22,6 \pm 1,9$ para $23,6 \pm 2,0$ ), enquanto o inverso aconteceu com o grupo experimental (de $5,5 \pm 0,9$ para $5,4 \pm 0,9$ ). Ainda, não houve diferença 
estatisticamente significante entre a força máxima de mordida dos indivíduos que retornaram após 3 meses, comparada com a executada anteriormente $(p>0,05)$. O grupo controle foi capaz de manter a mordida por muito mais tempo que o

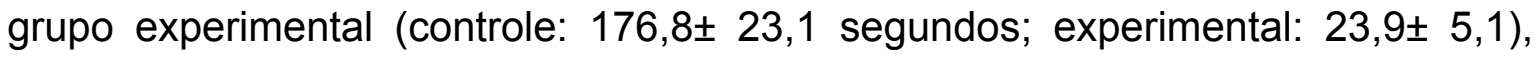
sendo essa diferença significante para $p>0,01$. Os autores chegaram a conclusão que mesmo após sustentar a mordida com $30 \%$ de sua força máxima durante um tempo, os indivíduos foram capazes de força máxima de mordida semelhante ou maior que a inicial, e que novos estudos com diferentes porcentagens de esforço sustentado devem ser realizados.

Com a proposta de testar a influência da abertura bucal, do suporte contralateral e da postura da cabeça durante a execução da força de mordida (engolindo, mastigando e máxima), FIELDS et al. ${ }^{14}$, em 1986 utilizaram transdutores de força confiáveis e aprimorados. Para mensurar a força com aberturas de 2,5 e $6 \mathrm{~mm}$, selecionaram 3 amostras, a primeira com 17 crianças (8 meninas e 9 meninos, de 6 a 12 anos, em média 9,3 anos), a segunda com 10 adolescentes (6 meninas e 4 meninos, de 11 a 15 anos, em média 13,1 anos) e a terceira com 21 adultos jovens (12 mulheres e 9 homens, de 24 a 35 anos, em média 26,9 anos), todos com proporções faciais normais. Para medir a força com abertura de $2,5 \mathrm{~mm}$ de separação entre os primeiros molares, foi utilizado um transdutor de força fabricado pelos autores e para a medida com separação de $6 \mathrm{~mm}$, foi utilizado um transdutor de força pré-fabricado. A região selecionada foi a de $1^{\circ}$ molar. A força durante a deglutição foi medida colocando $2 \mathrm{ml}$ de água na boca dos indivíduos, a força de mastigação, pedindo para que os indivíduos 
executassem a força necessária para mastigar carne e foi mensurada também a força máxima de mordida de todos esses indivíduos. Após isso, foi medida a força máxima de mordida, apenas dos adultos jovens, com diferentes aberturas bucais $(10,15,20,25,30,35$ e $40 \mathrm{~mm})$, acrescentando resina sobre o transdutor de força. Ainda foi medida a força máxima com aberturas de 2,5 e $6 \mathrm{~mm}$, com e sem suporte contra-lateral, apenas nos adolescentes. E por fim, foi aferida a força, também só para os adolescentes, com alterações da postura da cabeça (posição natural, $20^{\circ}$ de extensão e $20^{\circ}$ de flexão). Todos os testes foram repetidos 5 vezes. A análise dos resultados foi feita através do teste estatístico não paramétrico de Wilcoxon, com $p=0,01$. Os resultados encontrados demonstraram que a força durante a deglutição e a mastigação foram significantemente maiores com $6 \mathrm{~mm}$ de abertura que com $2,5 \mathrm{~mm}$, para as crianças, porém para os adolescentes, apesar dos valores também serem maiores com $6 \mathrm{~mm}$ de abertura, isso não foi significante, e para os adultos, isso só foi significante no que diz respeito à força de deglutição. Quanto à variação da força com o aumento da abertura, encontrou-se que a mesma aumentou até a abertura de $20 \mathrm{~mm}$, depois diminuiu até a abertura de $30 \mathrm{~mm}$ e aumentou novamente conforme a abertura foi aumentando. No que diz respeito à existência ou não de suporte contra-lateral e postura da cabeça, não houve diferença estatisticamente significante quando se utilizou ou não suporte e nem quando se alterou a postura da cabeça. Com isso concluiu-se que as medidas de força oclusal não são afetadas por suporte contralateral, que a postura da cabeça deve ser controlada, pois pode haver interação com a abertura bucal, e que a característica da curva dos valores de força com 
diferentes aberturas se deve à utilização de diversos músculos para produzir tal esforço.

Em 1986, GIBBS et al. ${ }^{15}$ avaliaram os limites da força de mordida humana sob a hipótese de que a força de mordida de bruxômanos é subestimada. A força de mordida dos pacientes foi mensurada através de um gnatodinamômetro desenvolvido para essa pesquisa, tal aparelho media a força dos lados direito e esquerdo ao mesmo tempo. O esforço era realizado pelos segundos présmolares, primeiros molares e segundos molares. O maior valor de força de mordida foi encontrado para um homem de 37 anos (975 lbs $=443 \mathrm{Kg}$ ). Tal indivíduo apresentava facetas de desgaste, hipertrofia do masséter e temporal, levando os autores a considerarem-no bruxômano. Seus músculos não apresentavam sensibilidade à palpação e sua ATM era assintomática. A segundo maior força de mordida encontrada foi realizada por um homem de 43 anos $(514 \mathrm{lbs}=234 \mathrm{Kg})$, que também apresentava hipertrofia de masséter e facetas de desgaste. A força de mordida de pacientes normais já havia sido reportada pelos autores 5 anos antes, utilizando a mesma metodologia, e demonstrou valores de 55 a 280 lbs, com média de 162lbs, o que representa 25 a $127 \mathrm{Kg}$ com média de $74 \mathrm{Kg}$. Com isso os autores concluíram que o valor da força de mordida humana tem sido subestimado, e que alguns bruxômanos podem executar força de mordida até 6 vezes maior que pacientes não bruxômanos.

AGERBERG ${ }^{1}$, em 1988 comparou a força de mordida, em ambos os lados, em pacientes que sofreram cirurgia unilateral de ATM. Doze pacientes foram 
eleitos (5 homens e 7 mulheres), com idades de 20 a 53 anos, todos tiveram dor crônica na ATM e DTM severa sem sucesso na tentativa de diversos tratamentos conservativos, esses pacientes possuíam dentição completa, incompleta ou eram edêntulos. Em 10 casos foi realizada a remoção do disco, e nos outros 2 casos o côndilo foi removido. A força de mordida foi mensurada 1 a 4 anos após a cirurgia, com o mesmo dinamômetro utilizado por LINDERHOLM E WENNSTROM ${ }^{32}$, em 1970. A região avaliada foi de prés-molares e molares, dependendo do estado da dentição do paciente. A força de mordida foi realizada em diferentes intensidades (1-muito fraca, 2-fraca, 3-nem fraca nem forte, 4-forte, 5-máxima) sem sentir dor na ATM ou outra parte do sistema mastigatório, nos lados operado e não operado. Teste de T pareado com $p>0,05$ foi aplicado. A média da força máxima de mordida foi maior para os pacientes que sofreram condilectomia, porém sem representar diferença estatisticamente significante. Entre os lados operado e não operado também não houve diferença estatisticamente significante entre os valores de força. Apesar disso, entre os indivíduos os valores foram muito variáveis, o que pode ser justificado pela variedade de condições de dentição. 0 autor concluiu que seria válido, em novos estudos, incluir a mensuração da força de mordida antes da cirurgia.

Com o intuito de avaliar o possível efeito do tratamento em pacientes com DTM de origem muscular em relação à sua força de mordida e sua percepção para discriminar vários níveis de força, em diferentes regiões do arco dental, OW, CARLSSON e JEMT ${ }^{46}$, em 1989, selecionaram 10 pacientes do gênero feminino, com idades entre 18 e 40 anos, com dentição completa e saudável e DTM de 
origem neuromuscular diagnosticada. As pacientes foram tratadas com placas oclusais estabilizadoras, aconselhamento, fisioterapia, ajuste oclusal e biofeedback (através de eletromiografia). Retornos regulares foram realizados para reforçar o aconselhamento e ajustar as placas. $O$ índice anamnésico de Helkimo foi registrado antes e após o tratamento (5 a 8 semanas), esse índice era derivado de respostas a um questionário, e cada paciente era classificado em uma graduação de suave a severa. Um escore de DTM, variando de 0 a 5 , também foi registrado para cada aspecto clínico, como mobilidade da mandíbula reduzida, função das ATM reduzida, dor à palpação dos músculos mastigatórios e ATM, e dor durante movimentação mandibular. A força de mordida foi mensurada utilizando um medidor de força montado em um garfo de mordida metálico. As áreas selecionadas foram: pré-molar ou molar direito, canino direito, incisivo central, canino esquerdo, e pré-molar ou molar esquerdo. Para cada posição, 3 níveis de força foram registrados: fraca, como se estivesse mordendo um sanduíche e forte. A força máxima, em uma região selecionada pela paciente, também foi registrada. Finalmente a força máxima dos dedos das mãos, direita e esquerda, também foi registrada. No grupo controle de 6 indivíduos (4 homens e 2 mulheres, com idades entre 22 e 29 anos), sem sinais e sintomas de DTM, os mesmos registros foram realizados, mas apenas em uma ocasião. ANOVA, T pareado e coeficiente de correlação foram os testes estatísticos aplicados aos resultados. Antes do tratamento, 5 pacientes foram consideradas com DTM severa e 3 com DTM suave, segundo o índice amanmésico utilizado, as outras 2 tinham dor de cabeça crônica e bruxismo. A redução dos sintomas foi relatada por 8 pacientes, mas em 4 dessas pacientes o índice não se alterou. As pacientes 
com dor de cabeça também relataram melhora nos sintomas. Já para o índice de DTM clínico, todas foram classificadas como tendo DTM moderada ou severa. Os sintomas eram bilaterais em 6 pacientes. Depois de 5 semanas de tratamento, uma melhora nas condições foi observada em 9 pacientes, pela redução do índice de DTM clínico. A única paciente que não teve esse índice diminuído relatou melhora dos sintomas também. A força de mordida foi estatisticamente diferente $(p<0,05)$, entre as regiões avaliadas, para cada intensidade de força, em ambos os grupos. Não houve diferença estatisticamente significante entre os registros realizados antes e após o tratamento das pacientes. Entre a força moderada dos dedos e a força de mordida fraca das pacientes, houve uma correlação $(p<0,05)$. As forças de mordida das pacientes eram sempre menores que as do grupo controle, e após o tratamento essa diferença passou a ser estatisticamente significante $(p<0,05)$ em $50 \%$ das categorias de força e posição. No grupo controle houve correlação positiva $(p<0,05)$ entre a força dos dedos e a força de mordida fraca nos incisivos, caninos e prés-molares e molares, em apenas uma ocasião para cada posição. Com esses resultados os autores concluíram que dor e desconforto nos músculos mastigatórios podem limitar os movimentos da ATM e a força de mordida, e que após o tratamento das DTM um mecanismo controla as atividades da ATM como um reflexo protetor para esses pacientes.

Já em 1990, LYONS e BAXENDALE ${ }^{36}$ avaliaram através de EMG, a capacidade de sustentação dos músculos masséter e temporal anterior, durante a aplicação de força máxima de mordida, comparando assim a força, o tempo e a resistência à fadiga de tais músculos, em indivíduos portadores ou não de 
bruxismo. Para tal selecionaram 10 homens, entre 32 e 60 anos, parcialmente dentados, 5 portadores de bruxismo e 5 no grupo controle. A força de mordida foi aferida utilizando garfo de mordida ligado a um transdutor, que foi devidamente calibrado antes de cada sessão. A EMG foi realizada através da colocação de eletrodos sobre o masséter e fibras anteriores do temporal. As medições foram realizadas no lado de preferência dos indivíduos. A força foi medida na região de canino, que era protegido com placas de resina acrílica para evitar fratura do esmalte e a espessura do garfo mais a placa era de $7 \mathrm{~mm}$. Depois de se familiarizar com o aparelho, os indivíduos eram instruídos a realizar a força máxima de mordida diversas vezes, intercalando com períodos de descanso, até que a força máxima tivesse sido claramente atingida. Após isso, eles eram solicitados a manter a força referente a $50 \%$ da força máxima pelo máximo de tempo possível. Através do teste T de Student, encontrou-se que a força máxima executada pelos pacientes portadores de bruxismo teve média de $26 \pm 2,59 \mathrm{Kg}$ e pelos indivíduos controle, $22 \pm 4,81 \mathrm{Kg}$. Além disso, os pacientes com bruxismo sustentaram $50 \%$ da força máxima por, em média, $2 \pm 0,3$ minutos, enquanto os indivíduos controle sustentaram por 1,6 0,15 minutos, porém essas diferenças entre os grupos não foram estatisticamente significantes. Os autores concluíram que a utilização de posição excêntrica durante a mensuração da força de mordida (região de canino), impossibilita que o mesmo grau de protrusão e lateralidade seja desenvolvido por todos os pacientes, sendo, portanto, uma limitação desse estudo, além disso, a utilização de transdutores com espessuras maiores do que seria funcionalmente normal (talvez $0,5 \mathrm{~mm}$ ), pode também ser uma limitação em estudos de fadiga e sustentação muscular. 
Ainda em 1990, STEGENGA, BROEKHUIJSEN e WILLIGEN ${ }^{56}$ compararam a capacidade e a precisão de pacientes com e sem DTM reproduzirem a força de mordida. Todos os pacientes passaram por exames clínico e radiográfico afim de detectar sinais e sintomas associados às DTM, incluindo: dor na ATM à palpação ou durante função, ruídos na ATM, hipermobilidade, sensibilidade dos músculos mastigatórios, padrão de abertura bucal, limites dos movimentos mandibulares, abertura passiva e facetas dentárias visíveis. Radiografia transcraniana foi feita para detectar alterações degenerativas nas ATMs ou diferença nas alturas dos ramos da mandíbula. Após isso, os indivíduos foram classificados como controle, pacientes com DTM articular e pacientes com alterações não articulares. O experimento foi realizado com 14 indivíduos, 7 no grupo controle (6 mulheres e 1 homem), e 7 no grupo experimental (5 mulheres e 2 homens), com idades entre 19 e 31 anos. Dos 7 indivíduos do grupo experimental, 3 tinham DTM articular (1- deslocamento do disco esquerdo com redução, 2- deslocamento do disco direito com redução, 3deslocamento do disco esquerdo sem redução), e 1 tinha DTM articular e alteração não articular (osteoartrose na ATM direita e bruxismo), e os outros 3, alterações não articulares (1- bruxismo, 2- bruxismo e cefaléia, 3- bruxismo e fibromialgia cervical). A força de mordida foi mensurada através de um transdutor munido de 2 medidores de força na lâmina superior. Os indivíduos foram instruídos a exercerem sua força de mordida com incisivos e caninos até ouvirem um sinal, então eles continuavam com essa força até se familiarizarem com a mesma. Depois de 4 segundos, um outro sinal era disparado e os indivíduos 
deviam exercer a mesma força que tinham exercido anteriormente. Esse teste foi executado com valores de 2, 10 e $50 \mathrm{~N}$ de força. Para cada valor de força foram realizadas 16 repetições por sessão, e 4 sessões por indivíduo, intercaladas por 1 semana. A média dos valores para cada valor de força foi calculada e utilizada como referência para medir a capacidade de reprodução de força de cada indivíduo. Não foi demonstrada tendência de subestimar a força quando o valor de referência foi de $10 \mathrm{~N}(p>0,05)$. Já para a referência de $2 \mathrm{~N}$, todos os indivíduos tenderam a exercer força maior e para $50 \mathrm{~N}$, menor $(p<0,05)$. Em apenas 2 ocasiões houve diferença estatisticamente significante entre os grupos $(p<0,05)$. O que demonstra que a capacidade de reprodução da força de mordida não é diferente para pacientes com ou sem DTM, levando os autores à conclusão que a capacidade de reprodução da força de mordida pelos pacientes não é um bom instrumento para se avaliar durante diagnóstico.

Em 1992, BAKKE et al. ${ }^{7}$ avaliaram a espessura do músculo masséter e sua relação com a força de mordida, a atividade elétrica do músculo, fatores oclusais e morfologia facial. Para isso, 13 mulheres de 21 a 28 anos (média de 22,9 anos), sem DTM, com 24 a 29 dentes naturais erupcionados, foram selecionadas. As imagens de ultrassom do músculo masséter foram obtidas bilateralmente, primeiramente com as participantes relaxadas e depois durante a execução de força máxima, e a espessura do músculo foi medida diretamente na tela, com uma precisão de $0,01 \mathrm{~mm}$. Essa medida foi feita em três regiões do músculo (posterior, média e anterior). Além disso, o número de dentes em contato foi medido com o auxílio de papel celofane. Também foi realizada cefalometria de 
todas as voluntárias, onde foram avaliadas morfologia facial e dentoalveolar. A força de mordida foi aferida unilateralmente, na região de $1^{\circ}$ molar, em duas sessões separadas por uma semana. Em cada sessão eram feitas 4 medidas de cada lado, sendo a média dos valores utilizada com resultado. Finalmente, foi realizada EMG do músculo masséter, também de ambos os lados. Os dados foram analisados através de métodos estatísticos convencionais, testes de correlação de Spearman e Wilcoxon, com $p \leq 0,05$. A espessura do músculo aumentou significantemente quando estava contraído (comparando com o relaxamento), além disso, a região menos espessa foi a posterior $(8,83 \mathrm{~mm}$, em média durante relaxamento, e $9,84 \mathrm{~mm}$, em média quando contraído), seguida pela anterior $(10,87 \mathrm{~mm}$, em média durante relaxamento, e 11,80 $\mathrm{mm}$, em média quando contraído), sendo a região média a mais espessa $(11,08 \mathrm{~mm}$, em média durante relaxamento, e $12,57 \mathrm{~mm}$, em média quando contraído). A força de mordida e a atividade elétrica tiveram correlação positiva com a espessura do masséter, além disso, a altura anterior da face, a inclinação mandibular, a relação vertical maxilomandibular e o número de contatos oclusais tiveram relação com a espessura muscular em contração, mostrando que existe conexão clara entre a espessura do masséter e os parâmetros associados com sua ação. O ultrassom se mostrou como um método simples e reproduzível, que adiciona informações aos exames convencionais sobre a função dos músculos mastigatórios e suas interações com o sistema craniomandibular.

KILIARIDIS et al. ${ }^{25}$, em 1993 selecionaram 136 indivíduos de 7 a 24 anos para estudarem a relação entre força de mordida e morfologia facial, idade, força 
do dedo, altura e gênero. Tais indivíduos foram separados por idade em 3 grupos: 7 a 9 anos (29 garotas e 25 garotos), 10 a 13 anos (28 garotas e 17 garotos) e 20 a 24 anos (22 homens e 15 mulheres). Durante o exame intraoral foram registradas as relações oclusais. A morfologia facial foi determinada através de medidas em fotografias. Foram calculadas a altura da face e a relação altura $x$ largura. A força de mordida foi medida com o mesmo aparato utilizado por HELKIMO, CARLSSON e CARMELI ${ }^{21}$, em 1975, nos primeiros molares e incisivos centrais. A tolerância dos indivíduos para a força de mordida foi medida, em segundos, no $1^{\circ}$ molar do lado de preferência do indivíduo, quando eram instruídos a manterem a força máxima de mordida pelo maior tempo que conseguissem. A força máxima dos dedos das mãos foi medida dos dois lados. Cada esforço era realizado 2 vezes em cada posição e o maior valor obtido era usado como o de força máxima. Teste $T$ e análise de regressão múltipla foram utilizados para analisar os resultados. Os resultados mostraram que a altura dos indivíduos, evidentemente, aumenta com a idade $(p<0,0001)$. Para as crianças, a altura da face foi maior para os garotos $(p<0,0001)$. Para os adultos a proporção entre altura e largura da face foi maior para os homens $(p<0,007)$. Além disso, encontrou-se também que a força dos dedos aumenta com a idade $(p<0,0001)$, e que, para os adultos, foi maior nos homens $(p<0,0001)$. Ainda mais, existiu uma correlação positiva entre a força dos dedos e dos molares, quando todos os indivíduos foram avaliados. A força de mordida também aumentou com a idade $(p<0,0001)$, exceto para a força dos molares das garotas de 10 a 13 anos e para os incisivos dos homens de 20 a 24 anos. Além do mais a força de mordida dos homens adultos na região de molar foi maior que a das mulheres do mesmo 
grupo ( $p<0,011)$. Uma correlação positiva foi encontrada entre a altura dos indivíduos e a tolerância dos mesmos à força de mordida $(p<0,0001)$ e a força máxima dos molares $(p<0,002)$. Para todos os pacientes houve uma pequena relação entre altura da face e força de mordida dos incisivos. Os autores concluíram que nenhuma relação foi encontrada entre características faciais e força máxima de mordida dos molares ou tolerância à força de mordida, e que estudos longitudinais acompanhando o crescimento de crianças podem ser interessantes para avaliar a importância da influência muscular no crescimento facial.

Ainda em 1993, WALTIMO e KONONEN ${ }^{60}$, desenvolveram um novo sistema de registro da força de mordida, levando em conta a posição da mandíbula, a separação entre os arcos, a área de ligamento periodontal envolvida durante o esforço e o local de colocação do sensor, tal sistema foi desenvolvido para permitir o registro simultâneo da força de mordida unilateral (em Newtons) e do tempo de sustentação dos músculos mastigatórios (em segundos), através de um sensor metálico de $14 \mathrm{~mm}$ de espessura e $12 \mathrm{~mm}$ de largura, coberto por 2 $\mathrm{mm}$ de borracha em cada lado, para diminuir o impacto do dente com o metal. Após a realização da calibração do aparelho, 15 homens de 22 a 35 anos $(25,6$ anos, em média) e 15 mulheres de 20 a 26 anos (23,6 anos, me média), tiveram sua força máxima de mordida mensurada na região de $1^{\circ}$ molar, direito $\mathrm{e}$ esquerdo, e na região incisal, por 4 vezes em cada região, sendo o maior valor de cada região o utilizado com resultado. Além disso, os indivíduos eram questionados sobre o fator limitante da sua força de mordida (dor nos dentes, dor 
nos músculos, dor na ATM, necessidade de mais força muscular ou outra razão). A análise estatística foi feita pelos testes T e T pareado, com $p \leq 0,05$. A média da força executada pelos homens foi de $870 \mathrm{~N}$ no lado direito, $818 \mathrm{~N}$ no lado esquerdo e $287 \mathrm{~N}$ na região incisal, os valores correspondentes para as mulheres foram $598 \mathrm{~N}, 595 \mathrm{~N}$ e $243 \mathrm{~N}$, sendo apenas significantes as diferenças entre a força dos homens e das mulheres nas regiões de molar. Os fatores limitantes da força na região de molar para os homens foram: necessidade de maior força muscular (6 homens), dor na ATM (6 homens) e dor nos músculos (3 homens), já para as mulheres foram: necessidade de maior força muscular (10 mulheres), dor nos músculos (3 mulheres) e dor na ATM (2 mulheres). No caso do esforço incisal, os fatores limitantes para os homens foram: dor nos dentes ( 11 homens) e necessidade de maior força muscular (4 homens), já no caso das mulheres foram: dor nos dentes (8 mulheres), necessidade de maior força muscular (5 mulheres), dor na ATM (1 mulher) e dor nos músculos (1 mulher). Tais resultados levaram os autores a concluir que na região de molar a força realizada representa bem o potencial muscular máximo, e que os dentes e o ligamento periodontal executam importante função na regulagem da força de mordida na região incisal.

Em 1995, BRAUN et al. ${ }^{8}$ relacionaram a força máxima de mordida com idade, gênero, estatura, peso e tipo físico, para determinar se há relação com sinais e sintomas de DTM, ausência de elementos dentais ou tratamento ortodôntico prévio. 142 estudantes (86 homens e 56 mulheres), com idades entre 26 e 41 anos (média de 32,4 anos), sem ausência de mais de 1 dente por quadrante (exceto terceiros molares) foram avaliados. Aqueles que 
apresentassem limitação nos movimentos mandibulares, estalido acompanhado de dor ou dor na ATM eram considerados como portadores de sinais e sintomas de DTM. Um transdutor para medição da força de mordida foi desenvolvido exclusivamente para essa pesquisa, e era composto por um tubo de borracha conectado a um sensor de pressão. A pressão então era transformada em um sinal elétrico e transferida para um indicador digital. $\mathrm{O}$ beneficio desse aparato era que a força era mensurada dos dois lados ao mesmo tempo, e, além disso, devido à elasticidade do tubo, a força era melhor distribuída e a deformação do tubo dava aos indivíduos um maior grau de segurança, diferente dos aparatos com elementos metálicos de mordida. O tubo era posicionado na região de $1^{\circ}$ molar e $2^{\circ}$ pré-molar. Os estudantes eram instruídos a executarem a força máxima de mordida por 3 sucessivas vezes, descansando de 2 a 3 segundos entre cada esforço. O valor máximo foi usado como resultado para cada indivíduo. Os resultados obtidos indicaram que, para $p=0,0001$, a diferença de $814 \mathrm{~N}$ de força de mordida dos homens e $615 \mathrm{~N}$ das mulheres foi estatisticamente significante. As correlações entre força de mordida e idade, peso e estaturas foram baixas. Não foi encontrada diferença estatisticamente significante entre a força de mordida dos estudantes com história de tratamento ortodôntico prévio ou com presença de sinais e sintomas de DTM e os indivíduos normais. O que levou os autores à conclusão de que a idéia que pessoas com maior estrutura corporal, mais altas ou mais pesadas teriam força de mordida maior não pode ser confirmada por esse estudo.

Nesse mesmo ano, KILIARIDIS et al. ${ }^{26}$ selecionaram 54 indivíduos (30 homens, com 40 anos em média e 24 mulheres, com 28 anos em média), com 
dentição natural completa ou quase completa, para estudarem a relação entre morfologia craniofacial, características oclusais e força de mordida em pacientes com desgaste dentário avançado. Um exame clínico padronizado foi realizado e, além disso, modelos de estudo foram obtidos com o intuito de analisar as características oclusais e o desgaste dentário. Os indivíduos foram classificados, quanto à severidade do desgaste dentário, em: 0- sem facetas visíveis; 1- facetas em esmalte; 2- facetas em dentina; 3- facetas extensas em dentina (área de exposição de dentina $>2 \mathrm{~mm}^{2}$ ) e 4- desgaste em dentina secundária. A força de mordida foi aferida através de um garfo de mordida metálico provido de medidores de força e recoberto com borracha, para facilitar a mordida. Após a calibração do equipamento, os indivíduos foram instruídos a executarem diferentes níveis de força (máxima, mastigação e leve), em diferentes regiões ( $2^{\circ}$ pré-molar, canino e incisivo). Cada esforço era realizado 2 vezes, e a média desses valores era registrada. O tempo de sustentação que os indivíduos conseguiam manter, executando força máxima, até a exaustão, foi medido e qualquer sintoma (dor, cansaço), durante tal sustentação, foi registrado. Para a avaliação da morfologia craniofacial foram utilizadas radiografias cefalométricas. Teste T e correlação de Pearson foram utilizados para avaliar os resultados. As análises dos modelos revelaram $82 \%$ dos indivíduos classe I de Angle, 16\%, classe II e $2 \%$ classe III, nenhum caso de mordida aberta foi encontrado e apenas 1 indivíduo apresentou mordida cruzada unilateral. Além disso, a média de dentes por pessoa foi de 27, variando de 19 a 28 dentes, e a média do índice de desgaste dentário foi de 1,7 , sendo de 1,9 para os homens e 1,45 para as mulheres ( $p \leq 0,01$ ). Tanto para os homens quanto para as mulheres foram 
encontrados desgastes significantemente maiores nos dentes anteriores que nos dentes posteriores. A força máxima e o tempo de sustentação não diferiram significantemente entre os gêneros. O aumento da idade teve correlação com a diminuição da força. Porém, ao compararem tais dados com dados de indivíduos controle (médias dos padrões normais de adultos suécos), os autores puderam concluir que existe uma interdependência significante entre função muscular, desgaste dentário e morfologia dentofacial.

Ainda em 1995, WALTIMO e KONONEN ${ }^{61}$ estudaram a força de mordida, comparando indivíduos com ou sem sinais e sintomas de DTM, e ainda buscando alguma possível associação com gênero ou estrutura corporal. Para isso foram selecionados 129 indivíduos (56 homens e 73 mulheres), com idades entre 20 e 25 anos (23 anos em média). Os homens mediam entre 1,63 a 1,96 m (1,82 m em média) e pesavam de 60 a $119 \mathrm{Kg}$ (76 Kg em média) e as mulheres mediam entre 1,51 e $1,83 \mathrm{~m}$ (com média de $1,67 \mathrm{~m}$ ) e pesavam de 45 a $85 \mathrm{Kg}(59 \mathrm{Kg}$ em média). Todos tinham no mínimo dois pares de molares ocluindo de cada lado. Depois de responderem a um questionário, foram clinicamente examinados e classificados segundo o índice de disfunção de Helkimo. O aparelho utilizado para mensurar a força de mordida foi o mesmo que o utilizado pelos autores em estudo $^{\mathrm{xx}}$ dois anos antes. Depois de se familiarizar com o equipamento, cada indivíduo executou a força máxima de mordida, 3 vezes em cada uma das seguintes regiões: molares direito e esquerdo e incisivos, com 1 minuto de descanso entre os esforços. Após isso, o maior valor para cada região foi analisado como resultado. Então, os indivíduos foram questionados sobre o maior 
fator limitante durante os esforços: dor nos dentes ou estruturas de suporte, dor muscular, dor na ATM ou necessidade de maior força muscular. ANOVA, teste T, qui-quadrado e coeficiente de correlação de Pearson foram utilizados com $p \leq$ 0,05. Os valores de força de mordida na região de molar foram maiores para os homens $(909 \mathrm{~N})$ do que para as mulheres $(777 \mathrm{~N})$ para $p=0,0001$. A força máxima de mordida na região dos incisivos para os homens foi de $382 \mathrm{~N}$ e para as mulheres $325 \mathrm{~N}(p \leq 0,01)$. O fator limitante predominante para a região de molar foi a falta de maior força muscular, e para a região de incisivos foi a dor de dente ou estrutura de suporte. Homens e mulheres tiveram freqüência semelhante de sinais clínicos de DTM porém, as mulheres tiveram mais freqüentemente sensibilidade à palpação $(p \leq 0,05)$. Nenhum dos sinais e sintomas de DTM estava associado com a força máxima de mordida. Também não houve correlação entre peso e altura e a força máxima de mordida. Uma diferença significante entre o valor de força máxima de mordida entre os gêneros, tanto na região de molar quanto na de incisivos, foi claramente demonstrada, sugerindo que seria oportuno o desenvolvimento de trabalhos futuros sobre força de mordida para os gêneros separadamente.

Já em 1996, LAVIGNE, ROMPRÉ e MONTPLAISIR ${ }^{31}$ investigaram a validade de um critério de diagnóstico clínico de bruxismo noturno através de um estudo controlado por polissonografia. 18 bruxômanos e 18 não bruxômanos foram selecionados, sendo 9 homens e 9 mulheres no grupo experimental e 11 homens e 7 mulheres no controle. A média de idades no grupo experimental era

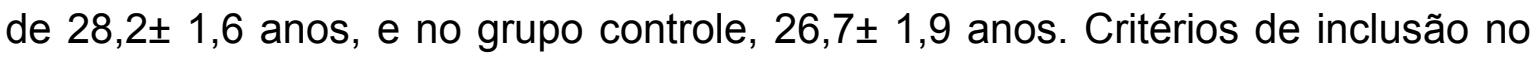


grupo experimental eram: idade entre 20 e 45 anos e nos últimos 6 meses, exibir ruídos noturnos, relatados por terceiros, pelo menos 5 vezes por semana. Além disso, tinham que apresentar ou facetas de desgaste, ou pontos brilhantes nas restaurações metálicas, ou fadiga nos músculos mastigatórios ao acordar, ou hipertrofia do masseter durante apertamento voluntário (avaliado através de palpação digital). Critérios de exclusão para tal grupo eram: mais de 2 dentes posteriores perdidos (exceto terceiros molares), presença de prótese dentária, maloclusão grosseira, uso de medicamentos com possíveis efeitos sobre o sono, abuso de drogas ou álcool, desordens neurológicas ou psiquiátricas, desordens do sono, epilepsia e apnéia. Para estar incluído no grupo controle eram seguidos os mesmos critérios, excluindo a presença de sinais e sintomas de bruxismo. Todos os indivíduos foram estudados em laboratórios de sono por duas noites consecutivas, sendo a $1^{a}$ para adaptação e a $2^{a}$ para coleta dos dados experimentais. Foram calculadas as seguintes variáveis do sono: tempo de sono, eficiência do sono, tempo de latência, $1^{\circ} \mathrm{REM}$, número de vezes que acordou durante a noite, movimentações, mudanças de estágios do sono, porcentagem de tempo de sono em cada estágio. Ainda, foi observada a movimentação das pernas durante o sono. Além disso, foi calculado o número de episódios de bruxismo por noite (eram expressos em episódios por hora de sono e "bursts" por episódio), e o número de atividades eletromiográficas que não relacionadas com bruxismo. A relação entre episódios de bruxismo com ruídos, movimentações corporais e movimentação das pernas, foi calculada. Para variáveis paramétricas, foram utilizados os testes T e ANOVA e para as outras variáveis, Wilcoxon, sempre com $p<0,05$. A sensibilidade e a especificidade dos resultados da 
polissonografia foram estimadas. No grupo experimental, 16 pacientes apresentavam facetas de desgaste associadas a ruídos noturnos, 6 tinham fadiga ou dor nos músculos ao acordar e 16 apresentavam hipertrofia do masséter. 0 número de episódios de bruxismo por noite e por hora foi três vezes maior, e significante, no grupo experimental. $80 \%$ dos episódios de bruxismo, de ambos os grupos, ocorreram nos estágios 1 e 2 do sono. Nenhuma das variáveis do sono apresentou diferença significante entre os grupos. Relatos de ranger noturno durante o exame inicial foram confirmados em laboratório, com sensibilidade de $78 \%$ e especificidade de $94 \%$, com o critério de 2 episódios de ranger por noite. Nesse estudo concluiu-se que o diagnóstico de bruxismo noturno pode ser feito através de polissonografia com valores de 4 ou mais episódios de bruxismo por hora e/ou 25 "bursts" de bruxismo por hora, mais, no mínimo, 2 eventos de ruídos noturnos. Além disso, o diagnóstico clínico de bruxismo foi correto em $81,3 \%$ dos casos no grupo controle, e em $83,3 \%$ dos casos no grupo experimental.

SINN, ASSIS e THROCKMORTON ${ }^{53}$, em 1996, determinaram como o tratamento cirúrgico de pacientes com diferentes tipos de DTM pode reduzir a limitação nos movimentos mandibulares e aumentar a força de mordida dos mesmos. Para esse fim, 25 mulheres, com idades entre 11 e 71 anos (35,8 anos em média), com cirurgia de ATM programada foram selecionadas para o grupo experimental. Tais pacientes apresentavam desordens internas com significante deslocamento do disco, deslocamento crônico e sub luxação ou osteoartrite. O grupo controle era composto de 26 mulheres, com idades entre 23 e 45 anos (29,4 anos em média), sem história de DTM. Durante o exame clínico, abertura 
máxima, lateralidade e protrusão foram medidas. Também foi avaliada a presença ou não de estalido. Foram levados em conta a utilização de medicamentos ou tratamentos anteriores. As intervenções cirúrgicas realizadas incluíam: reposicionamento do disco, remoção do disco com reconstrução do músculo temporal, eminectomia e raspagem da cabeça do côndilo com posterior reposicionamento do disco. Os limites dos movimentos excursivos (abertura máxima, máxima lateralidade durante abertura, desvio durante abertura, máxima movimentação posterior durante abertura, lateralidades e protrusão) e mastigatórios (máxima abertura, movimentação lateral, vertical e posterior durante mastigação), foram medidos através de um localizador magnético, antes da cirurgia e nos intervalos de 6 semanas, 6 meses e 1 ano após a cirurgia. Os testes de movimentos excursivos foram repetidos 5 vezes, sendo o maior valor o utilizado como resultado. Para o teste mastigatório, as voluntárias recebiam um chiclete e mastigavam naturalmente por 10 ciclos, depois o teste era repetido com um novo chiclete. A força máxima de mordida foi mensurada, com um aparelho feito sob encomenda, nas regiões de incisivos centrais, caninos, primeiros présmolares e primeiro molares, de ambos os lados. Para avaliar os resultados foi utilizada ANOVA a um critério e Tukey, quando necessário. Antes da cirurgia todos os movimentos excursivos das pacientes com DTM foram significantemente menores que das do grupo controle, exceto para as lateralidades e desvios na abertura, além disso, todos os movimentos mastigatórios foram menores para o grupo com DTM. Seis semanas após a cirurgia, a abertura máxima, as lateralidades durante abertura e máxima movimentação posterior durante abertura foram maiores que antes da cirurgia, já todos os outros movimentos diminuíram e 
foram significantemente menores que os do grupo controle. Ainda nessa etapa, os movimentos mastigatórios posteriores tiveram valores aumentados. Após 6 meses da realização da cirurgia, todos os movimentos aumentaram, exceto desvios na abertura e protrusão, e nessa mesma ocasião todos os movimentos, exceto desvios durante abertura, continuaram significantemente menores que os do grupo controle, e nos movimentos mastigatórios, a abertura incisal e vertical diminuíram e tornaram-se significantemente menores que as do grupo controle. Um ano após a cirurgia, todos os movimentos continuaram crescendo, e somente a protrusão continuou significantemente menor que a do grupo controle. Por outro lado, nos movimentos mastigatórios, a movimentação posterior não se alterou e os valores de abertura incisal e vertical continuaram diminuindo. A força máxima de mordida, antes da cirurgia, foi significantemente menor para as portadoras de DTM que para as não portadoras, após 6 meses a mesma aumentou para todas as regiões, e continuou aumentando até 1 ano após a cirurgia, quando se tornou muito próxima da do grupo controle. Tudo isso levou os autores a concluírem que pacientes com restrições severas nas funções da ATM tendem a exibir melhoras em alguns dos movimentos mandibulares e em sua força máxima de mordida, após a cirurgia.

Em 1998, TORTOPIDIS et al. ${ }^{58}$ mensuraram a força máxima de mordida com 3 diferentes transdutores, em diferentes ocasiões para determinar a confiança dessas mensurações. Para tal, 8 homens, de 25 a 32 anos, com dentição natural completa, sem dor ou estalido na ATM e nem dores musculares, foram selecionados. Um transdutor de aço inoxidável e unilateral foi utilizado para 
mensurações entre $2^{\circ}$ pré-molar e $1^{\circ}$ molar de um só lado, outro transdutor de aço inoxidável, porém bilateral, foi utilizado para mensurações entre $2^{\circ}$ pré-molar e $1^{\circ}$ molar de ambos os lados, e um último transdutor, também de aço inoxidável, anterior, avaliou a força entre incisivos e caninos. Após se familiarizar com os aparelhos, os indivíduos realizaram a sua força máxima de mordida 5 vezes em cada aparelho, descansando 30 segundos entre cada esforço. Três sessões, intercaladas por uma semana, foram realizadas. Os resultados demonstraram que os maiores valores encontrados foram obtidos com o transdutor bilateral (579 N, em média) e os menores com o anterior (286 N, em média). Para o transdutor unilateral, o valor médio encontrado foi de 428 N. Em conclusão os autores relataram que quanto maior o número de dentes posteriores envolvidos, maior será a força máxima de mordida obtida, além disso, complementaram que o design do aparelho utilizado também é importante para o resultado, em particular a facilidade de estabilização do aparelho entre os dentes, a capacidade de ser reposicionado na mesma posição intraoral várias vezes e a capacidade de proporcionar uma superfície para mordida confortável. Ainda nessa pesquisa, foi notado que a força máxima de mordida é melhor reproduzida quando se lança mão de um aparelho unilateral posterior. Quanto às sessões, nenhuma diferença estatisticamente significante foi encontrada para a força máxima de mordida nas três diferentes ocasiões.

Em 1999, MIYAURA et al. ${ }^{41}$ avaliaram a influência do gênero, idade e número de dentes na pressão de mordida, força de mordida e área de contato oclusal, em um trabalho de levantamento. Além disso, compararam esses valores 
entre indivíduos com e sem mobilidade dentária, em um estudo controlado. No levantamento foram avaliados 687 voluntários, com idades entre 15 e 99 anos

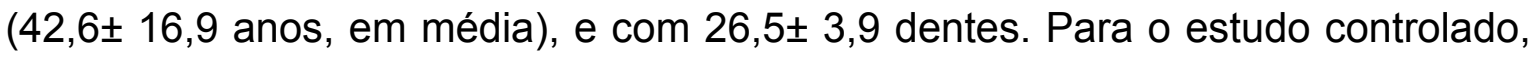
2 profissionais calibrados examinaram a presença ou não de mobilidade dentária nos 687 voluntários, e selecionaram 30 pacientes com mobilidade dentária e 30 sem, com idade média de $46 \pm 16,7$ anos e 26,6 dentes, tendo 11 homens e 19 mulheres em cada grupo. No grupo experimental, os indivíduos tinham, em média, 5,4 dentes com mobilidade. Para a avaliação da força de mordida, área de contato oclusal e pressão oclusal foi utilizada uma lâmina detectora de pressão (Prescale ${ }^{\circledR}$ ), onde cada indivíduo era instruído a realizar sua força máxima de mordida em $\mathrm{MIH}$, então ao remover a lâmina da cavidade bucal, eram observadas as áreas de contato, além disso, a lâmina possuía 8 graus de densidade, que indicavam o grau de pressão oclusal. A força de mordida era determinada através de cálculo matemático, levando em consideração a pressão e a área de contato de cada região. Os resultados do estudo de levantamento foram: a pressão de mordida não demonstrou alteração com a idade para os homens, porém no caso das mulheres, a mesma aumentou; para todas as idades, a força de mordida e a área de contato oclusal foram maiores para o gênero masculino, além disso, nos homens esses valores aumentaram até os 30 anos (onde foi obtido o valor máximo), e tiveram expressiva queda após os 50 anos. Ainda encontraram que pessoas com menos de 20 dentes executam maior pressão de mordida que as outras, mas, por outro lado, a força de mordida e a área de contato oclusal aumentam com o número de dentes presentes, para ambos os gêneros. Por exemplo, a força de mordida e a área de contato oclusal são 2 vezes maiores 
para indivíduos com 28 dentes, quando comparados aos com 22 ou 23 dentes. Já no estudo controlado, foi observado que não existiu diferença entre a força de mordida, a pressão de mordida e a área de contato oclusal de pacientes com ou sem mobilidade dentária. Em conclusão, relatou-se que o número de dentes é muito importante na manutenção da capacidade de mordida, e a mobilidade dentária não reduz essa capacidade sempre, portanto, a extração de dentes com mobilidade requer prudência por parte do profissional.

Com o objetivo de classificar o bruxismo segundo o grau de severidade, avaliar a prevalência de DTM nos bruxômanos, testar a hipótese de que exista uma maior prevalência de determinadas DTM em portadores de bruxismo severo, MOLINA et al. ${ }^{43}$, em 1999 avaliaram 276 pacientes portadores de DTM (236 mulheres e 40 homens), com idades de 12 a 73 anos (média de 34,85 anos). Para classificar os pacientes como portadores de bruxismo leve, moderado ou severo foram aplicados questionários, considerada a história de sinais ou sintomas de bruxismo, realizados exame clínico (palpação muscular e da ATM, avaliação dos movimentos mandibulares, análise da oclusão, busca por trigger points), radiográfico (panorâmica, transcraniana e tomografia, quando necessário) e analisados modelos de gesso. Após isso os pacientes portadores de sinais e sintomas de bruxismo foram classificados baseando-se em informações como: presença de facetas de desgaste; história recente de ruídos noturnos associados a ranger de dentes, relatados por amigos, parentes ou cônjuge; relato de apertar ou ranger os dentes durante o dia; relato de se sentir tenso durante o dia ou ao acordar; relato de acordar durante a noite apertando ou rangendo os dentes; 
hipertrofia do masséter e/ou temporal; fadiga muscular, no masséter, ao acordar ou durante o dia; relato de acordar durante a noite ou pela manhã com as ATM travadas; dor cervical, no masséter ou temporal ao acordar; sentir fadiga e/ou cansaço ao acordar; dor ou desconforto nos dentes ao acordar e história recente de deslocamento de restaurações, que lhes rendeu um score, utilizado para classificá-los como bruxômanos leves, moderados ou severos. Dos 276 indivíduos, 100 (36,23\%) eram bruxômanos leves, 66 (23,91\%) eram bruxômanos moderados e $45(16,30 \%)$ eram bruxômanos severos. Portanto, a prevalência do bruxismo leve, dentre os 211 indivíduos bruxômanos, foi de $47,39 \%$, contra os $31,27 \%$ do bruxismo moderado e $21,33 \%$ do severo. Os resultados obtidos sugeriram que o bruxismo severo é muito prejudicado pelas DTM.

RAADSHEER et al. ${ }^{50}$, nesse mesmo ano, estudaram a contribuição do tamanho dos músculos mastigatórios e da morfologia facial na força máxima de mordida. Selecionando para isso 121 indivíduos (58 homens e 63 mulheres) de 18 a 36 anos (23 anos, em média), saudáveis, sem malformações faciais, com dentição completa ou quase completa, sem maloclusões extremas ou desordens funcionais. A força máxima de mordida foi medida através de um transdutor de força, que era posicionado na região de caninos, entre 2 placas oclusais, feitas sobre modelos de gesso montados em articulador. Tais medidas foram repetidas 5 vezes, com intervalos de 1 minuto, sendo feita a média das 2 medidas com valores mais próximos. A morfologia craniofacial foi estudada em radiografias cefalométricas. A espessura muscular do masséter, temporal e digástrico anterior foram medidas através de imagens bilaterais de ultrassom, com os indivíduos 
relaxados. Os registros foram repetidos e a espessura final considerada foi obtida pela média das duas medidas. Além disso, peso e altura foram registrados como co-variáveis estatísticas. Os dados foram avaliados através do teste estatístico MANOVA. A média de força de mordida foi maior para os homens, porém essa diferença não foi estatisticamente significante. A morfologia facial também não foi significantemente diferente entre os gêneros. $58 \%$ da variância desse estudo pôde ser explicada pela variação do tamanho dos músculos e da morfologia craniofacial, sendo que, dos músculos estudados, somente a espessura do masséter mostrou relação significante com a magnitude da força de mordida, e das dimensões craniofacias. Somente os componentes verticais e transversais demonstraram relação positiva e significante com a magnitude da força de mordida. Os achados desse estudo levaram os autores a sustentar a idéia de que variações na magnitude da força de mordida dependem de variações do tamanho e direção do músculo masséter, e que essa direção está relacionada com variações na morfologia craniofacial.

Ainda em 1999, YOUNG et al. $^{59}$ se propuseram a encontrar novas informações relativas à morfologia dentofacial de bruxômanos e não bruxômanos. Para isso selecionaram 28 indivíduos saudáveis, de 22 a 35 anos, com, no mínimo, 27 dentes e dispostos a participarem da pesquisa. Foram obtidos modelos de gesso de todos os indivíduos, que eram classificados como bruxômanos ou não através da porcentagem de dentes apresentando facetas de desgaste (para ser classificado como bruxômano tinha que ter facetas em, no mínimo, 90\% dos dentes, já no grupo de não bruxômanos, eram aceitas facetas 
em até $60 \%$ dos dentes) e pelas respostas ao seguinte questionário: 1-história de apertar ou ranger, fadiga ou sensibilidade na ATM ou músculos mastigatórios; 2dores de cabeça; 3-dores no pescoço ou ombros; 4-sensibilidade dentária; 5trauma na cabeça ou pescoço; 6-tratamento ortodôntico prévio. Para estar no grupo experimental era necessário, além das facetas, responder "sim" para os itens 1 e/ ou 2 e "não" para os itens 3 a 6 . As medidas do comprimento e largura da cabeça e da face e altura facial foram registradas, além de outros dados cefalométricos. Após isso os indivíduos eram classificados segundo a forma da cabeça (dolico, meso ou braquicefálico), e o tipo facial (faces curta, média ou longa). O trespasse dos indivíduos foi mensurado através dos modelos de estudo, e a mordida foi classificada como aberta, normal ou profunda. Os testes estatísticos aplicados aos resultados foram MANOVA e ANOVA. Entre os grupos não foi encontrada diferença no número de dentes presentes, com média de 29 dentes por indivíduo, nem entre os trepasse, forma da cabeça ou tipo facial. Os bruxômanos apresentaram mais dentes desgastados que os não bruxômanos ( $p<$ 0,0001). Para os 2 grupos combinados, 17 indivíduos $(60,8 \%)$, sendo 9 bruxômanos e 8 controles, eram dolicocefálicos, outros 9 (32,1\%), 6 bruxômanos e 3 não, eram mesocefálicos, e os outros 2, um de cada grupo, eram braquicefálicos. Para os tipos faciais, 8 indivíduos (28,6\%), sendo 7 bruxômanos e 1 não, tinham face curta, além disso, 11, 4 bruxômanos e 7 controles, tinham face média, enquanto os outros 9, 5 bruxômanos e 4 não, tinham face longa. Portanto a hipótese suportada pelos autores de que bruxômanos tem feições menores e mais largas que os não bruxômanos, não pode ser confirmada por essa pesquisa, porém os autores puderam observar que o nível gengival tende a ser mais incisal 
nos incisivos centrais que nos laterais, em pacientes portadores de bruxismo. A conclusão final foi de que não existe relação entre forma da cabeça, tipo facial e trespasse entre bruxômanos ou não.

MANTYVAARA et al. ${ }^{38}$, também em 1999, avaliaram a associação entre bruxismo e alterações motoras no controle muscular dos músculos mastigatórios. Esse estudo teve um grupo de pacientes com bruxismo formado por 6 indivíduos (1 homem e 5 mulheres), com idades entre 24 e 29 anos (média de 26 anos), além disso, existiram 2 grupos controle, o primeiro constituído por 6 indivíduos saudáveis ( 3 homens e 3 mulheres), com idades entre 24 e 27 anos (26 anos, em média), e o segundo composto por 10 indivíduos saudáveis (5 homens e 5 mulheres), com idade entre 22 e 32 anos (25 anos, em média), todos os indivíduos e pacientes apresentavam dentição natural e contatos oclusais bilaterais simultâneos, sem apresentar maloclusão. Os pacientes com bruxismo reportaram episódios de ranger ou apertar os dentes em 1, 2 ou mais noites por semana, e, para confirmar o diagnóstico de bruxismo, os indivíduos foram clinicamente avaliados por um examinador. Para aferir a força de mordida foi utilizado o mesmo transdutor que WALTIMO e KONONEN ${ }^{60}$ utilizaram em 1993. A força foi mensurada entre os incisivos apenas segurando o transdutor em uma posição horizontal, com a adição de uma carga leve $(80 \mathrm{~g})$, com a adição de uma carga pesada (130g), com a adição de uma carga simuladora (visualmente idêntica à carga pesada mas com massa menos que $2 \mathrm{~g}$ ), com os olhos fechados e com o próprio indivíduo segurando o transdutor. Os resultados foram avaliados através de ANOVA e teste $T$ de student, com $p<0,05$. Os resultados mostraram 
um aumento de força com o aumento da carga para todos os indivíduos. Os pacientes com bruxismo executaram força de mordida maior que os indivíduos controle $(p<0,01)$, independente da carga. Para investigar a associação entre a falta de coordenação dos movimentos das mãos com a força de mordida, os autores compararam as forças de mordida com o transdutor empunhado pelo examinador e pelo examinado, e não encontraram diferenças quanto ao critério avaliado. O efeito visual da força de mordida foi avaliado pela comparação da força de mordida com olhos abertos e fechados, e, mais uma vez, os autores não encontraram diferença. No segundo grupo controle, os autores encontraram uma força de mordida significantemente maior $(p<0,001)$ nos indivíduos do gênero masculino que nos do gênero feminino. Com isso, os autores sugeriram que o controle motor envolvendo feedback visual e coordenação motora não são diferentes entre paciente com bruxismo e indivíduos controle.

Já em 2000, HATCH et al. ${ }^{19}$ definiram alguns determinantes da performance mastigatória em adultos dentados, através da seleção de 283 homens e 348 mulheres, com idades entre 37 e 80 anos (58,5 anos, em média). Gestantes ou pacientes portadores de próteses dentais removíveis foram excluídos. Então foram realizadas avaliações dental, periodontal e da performance mastigatória (através da pesagem de alimento teste submetido a uma peneira, após determinado número de ciclos mastigatórios), exame da ATM (pela utilização de um índice de DTM aplicado por um examinador calibrado) e mensuração de força máxima de mordida (com o auxílio de um transdutor de força de mordida bilateral na região de $1^{\circ}$ molar, sendo a média dos 3 maiores valores dentro de 10 esforços, o valor 
utilizado como resultado), contagem das unidades de dentes funcionais (cada unidade era definida por um par de dentes, pós canino, em oclusão) e secção transversal do masseter (medida utilizando um ultrassom de alta freqüência). Além disso, foi realizada uma revisão completa da história médica, farmacológica e física dos indivíduos, dando ênfase no que se refere à presença ou não de diabete mellitus. Tendo a idade, o número de unidades de dentes funcionais e a força máxima de mordida, um efeito pequeno sobre a performance mastigatória, por outro lado, o número de unidades dentais funcionais e o gênero tiveram grande efeito sobre a força de mordida, sendo que as mulheres tendem a apresentar valores de força de mordida menores que os dos homens. As DTM também exerceram influência na força de mordida, porém, baixa. Os resultados suportaram a hipótese de que a performance mastigatória é o resultado de uma complexa e simultânea inter-relação entre variáveis fisiológicas. Ainda, o número de unidades dentais funcionais e a força de mordida foram confirmados fortes determinantes, sugerindo que a manutenção desses fatores pode ser de grande importância para a função, portanto, a performance mastigatória não diminui com a idade se os dentes estiverem conservados e a força muscular mantida. Vale lembrar que além do número, a distribuição das unidades funcionais bilateralmente também é importante. Além disso, foi ressaltada a necessidade de estudos longitudinais para confirmar os resultados e refinar o modelo do estudo.

Com a proposta de examinar a força de mordida noturna, que ocorre durante o bruxismo, utilizando um novo detector de força de mordida, NISHIGAWA, BANDO e NAKANO ${ }^{4}$, em 2001, selecionaram 10 voluntários (8 
homens e 2 mulheres), com média de idade de 28,9 anos (de 23 a 36 anos), todos apresentando dentição completa, exceto terceiros molares. Todos os indivíduos responderam a um questionário, que revelou que metade deles era consciente de seu bruxismo noturno atual ou passado, três indivíduos exibiam estalido unilateral e, nenhum deles se submeteu a tratamento para DTM ou bruxismo. Em seguida, a força de mordida foi registrada através de um sistema composto por e placas resina acrílica (fabricadas para o arco superior e inferior de cada paciente), desenhadas de forma a manter contatos uniformes durante $\mathrm{MIH}$, que eram fixadas através de quatro grampos. Após isso, transdutores de força eram posicionados nas regiões de $1^{\circ}$ molar direito e esquerdo. Tal sistema era capaz de registrar força de mordida por até 23 horas. Inicialmente a força máxima de mordida durante o dia era registrada, sendo tal esforço realizado por três vezes, com 5 minutos de intervalo entre cada esforço, sendo a força máxima o esforço de maior resultado obtido entre os três realizados. A partir daí, a força de mordida noturna era medida por três noites consecutivas na casa de cada indivíduo, para isso, os indivíduos eram devidamente instruídos sobre o uso do detector de força de mordida. Os resultados demonstraram que a média da força de mordida durante os eventos de bruxismo noturno foi de $42,3 \mathrm{Kgf}$, e a duração média desses eventos foi de 7,1 s, além disso, o maior valor de força de mordida encontrado durante os eventos de bruxismo foi $81,2 \mathrm{Kgf}$, e a maior duração de um evento foi de $41,6 \mathrm{~s}$. A força máxima de mordida durante o dia teve média de 79,0 Kgf, atingindo o máximo valor de 99,7 Kgf. Nesse estudo não foi encontrada correlação entre força máxima de mordida diurna e parâmetros de bruxismo noturno (freqüência, amplitude ou duração dos eventos de bruxismo), porém, tais 
parâmetros demonstraram correlação significante com a força máxima de mordida noturna, sugerindo que pacientes portadores de bruxismo severo podem apresentar maior força de mordida durante a noite.

SONNESEN, BAKKE e SOLOW ${ }^{55}$, ainda em 2001 avaliaram se existe algum padrão consistente de associação entre a presença de DTM, as dimensões craniofaciais e a postura da cabeça, em crianças selecionadas para tratamento ortodôntico. A amostra utilizada foi de 96 crianças (51 meninas e 45 meninos), com idades entre 7 e 13 anos, sem anomalias craniofaciais, nem desordens musculares ou articulares sistêmicas. Esse estudo baseou-se em 4 exames: o exame funcional que consistia de uma entrevista (relato de dificuldade de abrir a boca, morder ou mastigar e relato de dores na face ou cefaléias); o exame clínico (avaliação dos movimentos mandibulares e ATM, palpação das ATM e musculaturas mastigatória, do pescoço e dos ombros), além disso, as crianças eram classificadas de acordo com o índice anamnésico e clínico de DTM de Helkimo; o exame da força de mordida, realizado na região de $1^{\circ}$ molar de ambos os lados, através de transdutor de força, a força máxima era registrada 8 vezes de cada lado e o valor máximo era utilizado com resultado e a análise cefalométrica, sendo que 42 referências eram utilizadas para descrever a morfologia craniofacial e a postura da cabeça e o exame de modelos de gesso onde se media a largura dos arcos dentais superior e inferior. A análise estatística foi realizada com o auxílio de um programa de computador, tendo $p<0,05$. Não existiu diferença entre as idades e o estágio de erupção dental, entre os gêneros. A sensibilidade muscular foi associada a indivíduos tipo "face longa" e a baixos valores de força de mordida. Cefaléias foram 
associadas a maxilares maiores e prognatismo. Os valores altos do índice de DTM de Helkimo foram associados a dimensões craniofaciais pequenas e baixos valores de força de mordida. As outras associações encontradas não foram significantes.

Nesse mesmo ano, os mesmos autores ${ }^{54}$ compararam a força máxima de mordida e a presença de sinais e sintomas de DTM em crianças com ou sem mordida cruzada. Para isso selecionaram 26 crianças com mordida cruzada (13 meninas e 13 meninos), com idades entre 7 e 13 anos, com indicação de tratamento ortodôntico, e 26 crianças controle (13 meninos e 13 meninas), com idades entre 7 e 13 anos, sem indicação de tratamento ortodôntico. Então foi aplicado um questionário (relato de dificuldade de abrir a boca, morder ou mastigar e relato de dores na face ou cefaléias) e realizado um exame clínico (avaliação dos movimentos mandibulares e ATM, palpação das ATM e musculatura mastigatória). O número de dentes em oclusão em MIH foi avaliado com o auxílio de papel celofane. A força máxima de mordida foi mensurada utilizando um transdutor de força unilateral, posicionado entre os primeiros molares de ambos os lados. Tal teste foi realizado 4 vezes de cada lado e nenhuma das crianças sentiu desconforto ou dor durante o teste. Os resultados foram analisados em um programa estatístico computadorizado, e os resultados foram considerados significantes quando $p<0,05$. No grupo experimental, 15 crianças apresentavam mordida cruzada unilateral no lado direito e 11, no lado esquerdo. 0 número de contatos oclusais desse grupo foi significantemente menor que o do grupo controle. O sintoma de DTM com maior prevalência no grupo experimental foi a cefaléia recorrente e o sinal foi o desconforto à palpação nos músculos temporal anterior e 
masséter superficial. Já no grupo controle, o sintoma mais prevalente foi a cefaléia semanal e o sinal foi o estalido. Quanto à força de mordida, em ambos os grupo seu valor aumentou com a idade e com o estágio de erupção dental, não havendo diferença significante entre os lados e nem entre os gêneros. A força máxima de mordida do grupo experimental foi significantemente menor que a do grupo controle. Entre todas as crianças percebeu-se uma correlação positiva entre idade, estágio de erupção dental e número de contatos dentários com a força de mordida. A conclusão de tal experimento foi que os achados confirmam que é aconselhável o tratamento de mordida cruzada unilateral em crianças (o quanto antes) para otimizar as condições de desenvolvimento e função do sistema estomatognático.

THROCKMORTON e ELLIS III $^{57}$, em 2001, avaliaram se indivíduos que sofreram grandes mudanças cirúrgicas (ortognática) e, provavelmente normalização de sua morfologia esqueletal, demonstram aumento em sua força máxima de mordida após a cirurgia. Para isso realizaram radiografias cefalométricas de 104 indivíduos adultos (32 homens e 72 mulheres). Para definir a forma craniofacial dos indivíduos diversas medidas cefalométricas foram realizadas nos cefalogramas antes e depois da cirurgia. A força máxima de mordida foi medida unilateralmente, através de um transdutor de força, nas regiões de incisivos centrais, caninos, prés-molares e molares, direito e esquerdo. A medida da força foi realizada antes da cirurgia, 6 meses, 1, 2 e 3 anos após a cirurgia, respectivamente. Os resultados demonstraram que a cirurgia ortognática produziu pequenas alterações na forma craniofacial dos indivíduos. Além disso, nenhuma correlação foi encontrada entre o aumento da força máxima de mordida 
e as mudanças produzidas na morfologia esqueletal ou outras variáveis biomecânicas. Tais dados levaram os autores a concluir que mudanças dentais, como o aumento da área de contato dentário, são mais importantes para o aumento da força de mordida que as mudanças na forma craniofacial.

Ainda em 2001, MIURA et al. ${ }^{40}$, examinaram a força de mordida de indivíduos de idade avançada e saudáveis, e comparam esses dados com os de indivíduos de idade avançada e debilitados. Para isso, 349 indivíduos saudáveis (149 homens e 200 mulheres) e 24 indivíduos debilitados (7 homens e 17 mulheres), de 65 a 74 anos, foram selecionados. Indivíduos debilitados foram definidos como indivíduos dependentes, ou seja, que não fazem nada sozinhos. Um exame intra oral foi realizado para determinar o número de dentes presentes. A força de mordida foi medida através de um sistema chamado Prescale ${ }^{\circledR}$ (CG Co. Ltda, Japão), no qual folhas sensíveis à pressão mostram uma variação de cor, dependendo da força executada. Cada indivíduo mordeu uma folha, em MIH, por 5s com força máxima. Os dados foram avaliados pelo teste não paramétrico Mann- Whitney e os resultados dessa avaliação demonstraram que a força máxima de mordida de homens saudáveis (408, em média), foi significantemente maior $(p=0,02)$ que a dos homens debilitados (196, em média). Porém, o número de dentes presentes não apresentou diferença significante entre esses dois grupos. Para as mulheres, a força máxima de mordida das saudáveis $(243,5$, em média), foi significantemente maior $(p=0,015)$ que a das debilitadas $(130,5$, em média). Porém, o número de dentes presentes não apresentou diferença significante entre esses dois grupos. Entre os indivíduos saudáveis, a força 
máxima de mordida dos homens (408, em média), foi significantemente maior ( $p=$ 0,000) que a das mulheres $(243,5$, em média). Porém, novamente, o número de dentes presentes não apresentou diferença significante entre esses dois grupos. Tais resultados levaram os autores a concluírem que indivíduos de idade avançada e debilitados têm alterações de força de mordida.

Nesse mesmo ano, ARIMA, ARENDT-NIELSEN e SVENSSON ${ }^{5}$, avaliaram o efeito da dor muscular aguda antes do sono, invocada pela injeção de capsaícina, na atividade motora orofacial durante o sono, em indivíduos com queixa de dor muscular e indivíduos sem queixa. Para tal, 9 homens e 3 mulheres, com idade média de 24 anos, saudáveis, foram selecionados. Todos apresentavam ranger noturno, relatado por parceiros ou familiares, além disso, em todos foi identificada a presença de facetas de desgaste por um examinador. Tais indivíduos foram subdivididos em dois grupos: com dor (5 indivíduos com idade média de 23,2 anos), e sem dor (7 indivíduos, com idade média de 25,1 anos), os indivíduos do grupo sintomático relataram dor ou desconforto muscular, em uma escala de análise visual, na manhã da noite controle, e os indivíduos controle não apresentavam queixa em suas ATM ou músculos mastigatórios. Inicialmente os indivíduos eram encaminhados para um laboratório de sono, onde dormiam por 3 noites consecutivas ( $1^{a}$ noite: adaptação, $2^{a}$ noite: controle, $3^{a}$ noite: experimental - capsaícina). Na noite experimental, os indivíduos recebiam uma injeção de capsaícina no músculo masséter. A distribuição e o limiar de dor, além da força máxima de mordida e da atividade eletromiográfica foram avaliados toda noite $\left(22: 30 \mathrm{~h}\right.$, na $1^{\mathrm{a}}$ noite, e $22: 00 \mathrm{~h}$, nas noites seguintes) e toda manhã 
(7:45h). Os indivíduos podiam ir para a cama a partir das 23:00h, e podiam ficar dormindo até às $7: 30 \mathrm{~h}$ do dia seguinte. A atividade eletromiográfica dos músculos masseteres das duas primeiras noites foi utilizada para definir o lado predominante, ou seja, o que apresentava maior atividade eletromiográfica, que foi utilizado para injeção de capsaícina. Os indivíduos preencheram escalas de análise visual (de $100 \mathrm{~mm}$ ) de dor e desconforto, toda noite, pelas manhãs e, novamente 5 e 15 minutos após a injeção de capsaícina. A força máxima de mordida foi mensurada através de um transdutor de força em forma de "U", medindo assim a força bilateralmente. A força era medida entre os primeiros molares, e os indivíduos eram instruídos para executarem força máxima por 3 a 4 segundos. Teste paramétrico "t" e MANOVA foram utilizados, com $p<0,05$. Os resultados demonstraram que após a injeção de capsaícina os escores das escalas de análise visual aumentaram progressivamente, atingindo um pico (indivíduos com dor: $48 \pm 8 \mathrm{~mm}$, indivíduos sem dor: $54 \pm 7 \mathrm{~mm}$ ), sem diferenças entre os grupos. Além disso, 5 minutos após a injeção de capsaícina, a área de dor era significantemente maior que a área de dor das duas primeiras noites $(p=$ $0,001)$, com diferença estatística entre os grupos $(p=0,043)$, sendo maior a área do grupo controle. A força de mordida não apresentou diferença significante entre os grupos, lado injetado ou não, noite controle ou experimental e manhãs. O presente estudo mostrou que pacientes com dor e desconforto nos músculos mastigatórios têm menor atividade motora orofacial durante a noite do que aqueles que não apresentam queixa. Além disso, o estímulo doloroso (capsaícina) aplicado ao músculo masséter antes do sono não alterou a atividade 
motora orofacial, o que sugere que a dor sozinha não pode ser associada a efeitos excitatórios na função motora mandibular humana.

No ano seguinte, RENTES, GAVIÃO e AMARAL ${ }^{51}$, se propuseram a estudar a força de mordida em crianças com primeira dentição e sua relação com variáveis oclusais e corporais. Selecionaram, então, 30 crianças brancas de ambos os gêneros, com idades entre 3 e 5,5 anos. Os critérios de inclusão utilizados foram: presença da primeira dentição, ausência de alterações de forma, número ou estrutura, tecidos orais normais e ausência de sinais e sintomas de DTM. A amostra foi dividida em 3 grupos de acordo com o tipo de oclusão, que podia ser normal (grupo I), mordida cruzada (grupo II) ou mordida aberta (grupo III). A força de mordida foi aferida através de um transdutor de força que consistia em um tubo de borracha conectado a um sensor, que era conectado a um conversor analógico/ digital. Cada paciente realizou força máxima de mordida 3 vezes por 5 segundos e intervalo de 10 segundos entre cada esforço, o maior valor de cada paciente foi selecionado e analisado por meio de métodos estatísticos convencionais, com $p<$ 0,05. Os resultados demonstraram que não existiu diferença significante entre os grupos, indicando que o tipo de oclusão, nesse estudo, não afetou a magnitude da força de mordida, além disso, também não houve diferença entre os gêneros.

Ainda em 2002, KLEINFELDER e LUDWIG ${ }^{27}$ estudaram a influência da doença periodontal na força máxima de mordida, em dentição natural, e ainda, os efeitos da esplintagem na força máxima de mordida. Dez pacientes (4 mulheres e 6 homens, de 42 a 53 anos, com média de 46,8 anos de idade) com doença 
periodontal crônica, avançada e tratada e perda óssea de $50 \%$ nas regiões de prés-molares e molares, foram selecionados. Outros dez indivíduos (4 mulheres e 6 homens, de 38 a 55 anos, com média de 45,4 anos de idade) com saúde periodontal também foram selecionados. A amostra foi separada por gênero e idade. O critério de inclusão era dentição natural completa e sem prótese em pelo menos um dos lados da boca. Os critério de exclusão incluíam desordens neurológicas, medicamentos, gestação e lactação. Clinicamente foi medida a profundidade de bolsa, o índice de placa e o índice gengival. Também foram realizadas radiografias periapicais de boca toda para se calcular a quantidade de remanescente ósseo. A força de mordida foi mensurada por meio de um transdutor de força. Inicialmente foram preparadas duas placas de acrílico de $2 \mathrm{~mm}$ de espessura para cobrir os primeiros prés-molares superior e inferior. As placas eram fixadas com cimento temporário e a força máxima de mordida era medida nessa região por 5 vezes. Depois disso era feita a média dos valores para cada paciente. Para avaliar o efeito da esplintagem, foram preparadas placas de acrílico cobrindo os 4 dentes posteriores superiores e inferiores, que foram também fixadas com cimento temporário. A força de mordida foi medida novamente na mesma região por 5 vezes, e realizada a média para cada paciente. Para comparar os resultados foi utilizado o teste $\mathrm{T}$ de Student. A profundidade de bolsa foi significantemente maior nos pacientes $(2,9 \mathrm{~mm}$ em média), que no grupo controle $(1,9 \mathrm{~mm}$ em média), com $p<0,05$, os valores de placa e índice gengival não apresentaram diferenças significantes entre os grupos. A média da força de mordida do grupo controle sem esplintagem foi de $357 \mathrm{~N}$ e do grupo experimental foi de $378 \mathrm{~N}$, após a esplintagem esses números aumentaram para $509 \mathrm{~N}$ no grupo controle e $534 \mathrm{~N}$ 
no grupo experimental, sendo que em nenhum dos casos as diferenças foram estatisticamente significantes, mostrando, segundo os autores, que pacientes com suporte periodontal reduzido estão aptos a gerar força de mordida com a mesma intensidade que pacientes periodontalmente saudáveis, e levando os autores a concluírem que a redução do periodonto não limita a força máxima de mordida na dentição natural.

KOVERO et al. ${ }^{28}$, em 2002, avaliaram a força máxima de mordida incisal e molar de adultos jovens e a associaram à postura e posição espinhal e à morfologia craniofacial. Para isso, selecionaram 84 indivíduos (46 homens e 38 mulheres). Um médico mensurou a simetria do tronco e postura espinhal. Foi também realizada radiografia cefalométrica da cabeça e pescoço para todos os indivíduos, que foram digitalizadas e avaliadas por um programa de computador. A força de mordida foi aferida na região incisal e regiões de molar direito e esquerdo, duas vezes em cada área. Os resultados foram analisados com o teste $\mathrm{T}$ de Student e com um programa estatístico de computador. Os resultados demonstraram valores de força de mordida significantemente maiores para os homens que para as mulheres (média nos molares: homens, $844 \mathrm{~N}$ e mulheres, $683 \mathrm{~N}$; média nos incisivos: homens, $286 \mathrm{~N}$ e mulheres, $237 \mathrm{~N}$ ). Não houve correlação entre força de mordida e as variáveis de postura espinhal. Nas mulheres houve correlação maior e mais forte entre a morfologia craniofacial e a força máxima de mordida que nos homens. Além disso, encontrou-se que os pacientes que apresentaram maiores valores de força de mordida apresentavam paralelismo entre os arcos, ou seja, menores ângulos craniomandibulares e 
maxilomandibulares. Pôde-se concluir que a postura espinhal não teve influência na magnitude da força mastigatória em adultos jovens, porém a morfologia craniofacial pôde ser associada com a força máxima de mordida, principalmente nas mulheres.

FERNANDES et al. $^{13}$, em 2003 testaram a exatidão, precisão e efeito sobre as estruturas de suporte de um novo sensor de força de mordida. Então, selecionaram 6 indivíduos ( 3 homens e 3 mulheres, com idades entre 57 e 72 anos), com boa saúde geral e portadores de prótese parcial removível. A força de mordida foi mensurada com o novo sensor (feito de silicone) e com um sensor convencional (feito de metal). Os teste foram realizados em dois experimentos idênticos, separados por 4 semanas. No $1^{\circ}$, os indivíduos executavam força máxima de mordida na região de pré-molar e molar direito e esquerdo (unilateralmente), na região de incisivos e, finalmente, bilateralmente na região de pré-molar. No segundo experimento, o mesmo foi realizado, porém ao invés de força máxima, os indivíduos executavam $80 \%$ da força máxima. Cada esforço era realizado por 2 segundo, com 10 segundos de separação entre cada esforço. Os resultados foram avaliados por análise se variância (ANOVA), com $p<0,05$. As forças realizadas variaram de 28 a 250 N. Houve diferença estatisticamente significante para as diferentes regiões de esforço para cada indivíduo, sendo que a região anterior teve o menor valor de força e a força medida bilateralmente (região de pré-molar) foi a de maior valor. Além disso, os homens realizaram força maior que as mulheres $(p<0,05)$. Os valores de força registrados com os dois sistemas mostraram-se semelhantes. Porém o novo sensor de força de mordida apresentou 
menos variância que o outro sistema $(p<0,05)$, indicando que o mesmo é capaz de reproduzir mais precisamente as condições estudadas. Levando os autores a concluírem que esse sensor é um sistema de mensuração promissor, que apresenta méritos clínicos a favor de seu uso. 
3. PROPOSIC̄ÕES 


\section{PROPOSIÇÕES}

Essa pesquisa teve como objetivos:

1. Avaliar a influência do gênero na força máxima de mordida;

2. Avaliar a influência do bruxismo na força máxima de mordida;

3. Avaliar a associação entre hábitos parafuncionais e o gênero do indivíduo;

4. Avaliar a concordância inter-examinadores para determinado exame físico de bruxismo. 
4. MATERIAL E MÉTODOS 


\section{MATERIAL E MÉTODOS}

\subsection{Comitê de Ética em Pesquisa}

Essa pesquisa foi aprovada pelo Comitê de Ética em Pesquisa da Universidade de São Paulo- Faculdade de Odontologia da Bauru no dia 13 de fevereiro de 2003, sob o processo número 146/2002. (Anexo 1)

\subsection{Amostra}

Para essa pesquisa, 120 indivíduos foram selecionados, sendo 30 bruxômanos do gênero masculino, 30 não bruxômanos do gênero masculino, 30 bruxômamos do gênero feminino e 30 não bruxômanos do gênero feminino.

As idades variaram de 14 a 44 anos, para toda a amostra. Para o gênero masculino, as idades variaram de 18 a 37 anos, enquanto as mulheres apresentaram idades entre 14 e 44 anos. Nos indivíduos portadores de bruxismo, as idades variaram de 14 a 44 anos e nos indivíduos controle, variaram de 18 a 37 anos. Os valores médios da idade dos indivíduos, por grupo e gênero, podem ser observados na Tabela 4.1. 
Tabela 4.1. Médias das idades dos participantes dessa pesquisa (em anos).

\begin{tabular}{c|c|c|c}
\hline Grupo & Gênero & Masculino & TOTAL \\
\hline Controle & 22,07 & 25,07 & 23,57 \\
\hline Experimental & 22,60 & 26,50 & 24,55 \\
\hline TOTAL & 22,33 & 25,78 & 24,06 \\
\hline
\end{tabular}

Todos os indivíduos receberam esclarecimentos sobre a pesquisa, bem como sobre os procedimentos que seriam realizados, através de carta de informação (Anexo 2), que Ihes era entregue previamente aos procedimentos. Após atenta leitura os indivíduos eram questionados sobre possíveis dúvidas. Então, os indivíduos assinavam o termo de consentimento livre e esclarecido (Anexo 3), concordando com sua participação na pesquisa.

O recrutamento dos indivíduos foi realizado entre alunos de graduação e pós-graduação e funcionários da Faculdade de Odontologia de Bauru, bem como entre os pacientes que se apresentavam ao setor de triagem dessa mesma instituição, para tratamento odontológico. 


\subsection{Critérios de seleção}

\subsubsection{Exame inicial e questionário de DTM}

Inicialmente, todos os indivíduos participantes da pesquisa foram submetidos a uma consulta inicial, constando de anamnese e exame físico, realizados por um único examinador.

A anamnese constou de: coleta dos dados pessoais, questionário geral sobre doenças sistêmicas, alergias e tratamentos médicos em andamento e questionário sobre hábitos parafuncionais, como apertamento, onicofagia e uso contínuo do telefone. (Anexo 3)

Foi, então, realizado o exame físico intra-oral, com atenção especial para presença de próteses e regiões desdentadas, má oclusão, como mordida aberta, cruzada ou profunda, e deslize de RC para MIH. (Anexo 4)

Com o objetivo de verificar a presença ou não de Disfunção Temporomandibular, um questionário de DTM foi aplicado, permitindo a classificação da amostra quanto a esse critério. (Anexo 5)

Para cada pergunta de tal questionário são oferecidas três possibilidades de resposta: SIM, NÃO e ÀS VEZES. Cada resposta "sim" recebe um escore 2, cada "às vezes" recebe um escore 1 e cada "não" recebe um escore 0 . As questões 6 e 7 recebem escore 3 para cada resposta "sim" correspondente a sintomas bilaterais e escore 2, para sintomas unilaterais. Além disso, na questão 4, o escore 3 será atribuído quando relatado que a dor for freqüente e intensa $(\text { CONTI, 2000) })^{11}$. 
A somatória dos valores obtidos permite a classificação da amostra em relação ao grau de Disfunção Temporomandibular em: não portador de DTM (escore total de 0 a 3), portador de DTM leve (escore total de 4 a 8), portador de DTM moderada (escore total de 9 a 14) ou portador de DTM severa (escore total de 15 a 23).

Para esta pesquisa foram selecionados indivíduos que apresentassem escores de 0 a 8 nesse questionário, ou seja, não portadores de DTM ou portadores de DTM leve.

\subsubsection{Critérios de exclusão inicial}

Para todos os participantes da pesquisa foram utilizados os seguintes critérios de exclusão inicial (baseados nos critérios sugeridos pela AADS, LAVIGNE, ROMPRÉ e MONTPLAISIR, 1996) ${ }^{31}$ :

1. Apresentação de dois ou mais dentes perdidos (excluindo-se os terceiros molares);

2. Utilização de prótese dental removível;

3. Presença de má-oclusão grosseira, especificamente, mordida aberta anterior, mordida cruzada unilateral, sobrepasse horizontal (overjet) maior que $6 \mathrm{~mm}$, interferência no arco de fechamento que provoque um deslize de RC para $\mathrm{MIH}$ maior do que $5 \mathrm{~mm}$ (características oclusais de risco para desenvolvimento de DTM, de acordo com PULLINGER, SELIGMAN e GORNBEIN, 1993) ${ }^{49}$.

4. Apresentação de grandes desordens neurológicas, psiquiátricas ou de movimento (KATO et al, 2001 e KATO et al, 2001) 23 e 24. 
5. Valores maiores que 8 no questionário de DTM. (Anexo 5)

\subsubsection{Critérios de inclusão geral}

Para ser incluído na amostra o indivíduo deveria:

- ter idade entre 14 e 45 anos;

-apresentar todos os primeiros molares na boca, íntegros ou restaurados;

- somar escore de 0 a 8 no questionário de DTM;

\subsection{Estabelecimento dos grupos}

Para o estabelecimento dos grupos, foi utilizado um questionário e um exame físico específicos para o bruxismo. O exame físico foi realizado por três examinadores, alunos de pós-graduação em Reabilitação Oral nesta Instituição.

Tanto o questionário quanto o exame físico eram realizados em um mesmo dia pelos três examinadores, porém não estabeleceu-se uma seqüência de exame. Além disso, aos examinadores eram mascarados os resultados obtidos pelos outros examinadores.

O questionário foi desenvolvido através da modificação do questionário utilizado por MOLINA et al. ${ }^{43}$, em 1999 (Anexo 6), sendo composto por 6 questões sobre sintomas de bruxismo, sendo que para cada questão os indivíduos poderiam responder SIM, NÃO ou ÀS VEZES. 
Como para esse questionário não existe um escore a partir das respostas obtidas, estabeleceu-se para os examinadores que duas ou mais respostas "sim" ou "às vezes" sugeriam de presença de bruxismo.

$\mathrm{Na}$ segunda etapa do exame de bruxismo, os três examinadores foram adequadamente calibrados para a realização do exame físico. Para isso, examinaram alguns pacientes, até atingirem concordância adequada entre si.

Esse exame físico de bruxismo foi derivado dos resultados de LAVIGNE, ROMPRÉ e MONTPLAISIR ${ }^{31}$, em 1996, onde era observada a presença de facetas de desgaste oclusal coincidentes, não importando sua localização, nem o número de dentes facetados. Tinham, no entanto, de contactar-se durante os movimentos excursivos de lateralidade ou protrusão realizados exclusivamente pelo indivíduo, sendo assim classificadas como coincidentes, consistindo em um fator sugestivo de presença de bruxismo.

Após isso foi observada a presença de pontos ou áreas brilhantes em restaurações de amálgama ou metálicas fundidas, sendo também um fator sugestivo de presença de bruxismo.

O último item avaliado foi a hipertrofia do músculo masséter durante apertamento voluntário, que foi considerada positiva (sugerindo presença de bruxismo), se o examinador constatasse, por meio de inspeção digital, que seu volume havia triplicado com o apertamento voluntário.

Para esse exame físico, também não existe um escore, sendo que através dos resultados encontrados no questionário e exame físico de bruxismo, cada examinador classificava o indivíduo como bruxômano ativo (grupo experimental) ou não (grupo controle). Portanto, ao final do exame, cada indivíduo havia sido 
examinado pelos 3 examinadores e recebia de cada um deles um diagnóstico final (bruxômano ou não). Quando 2 examinadores consideravam o indivíduo como bruxômano, o mesmo era incluído no grupo experimental (bruxismo).

\subsection{Registro da força de mordida}

\subsubsection{Aparelho utilizado}

Para a obtenção das forças de mordida foi utilizado o dinamômetro digital, modelo IDDK (Kratos Equipamentos Industriais Ltda, Cotia, SP), número de série 3222, ano 2002, adaptado para as condições bucais (Figura 4.1), gentilmente cedido pelo Departamento de Prótese da Faculdade de Odontologia de BauruUSP. Esse aparelho é um instrumento de medição de força eletrônico, composto por um garfo de mordida (Figura 4.2) e um corpo digital (Figura 4.3), interligados por um fio. 


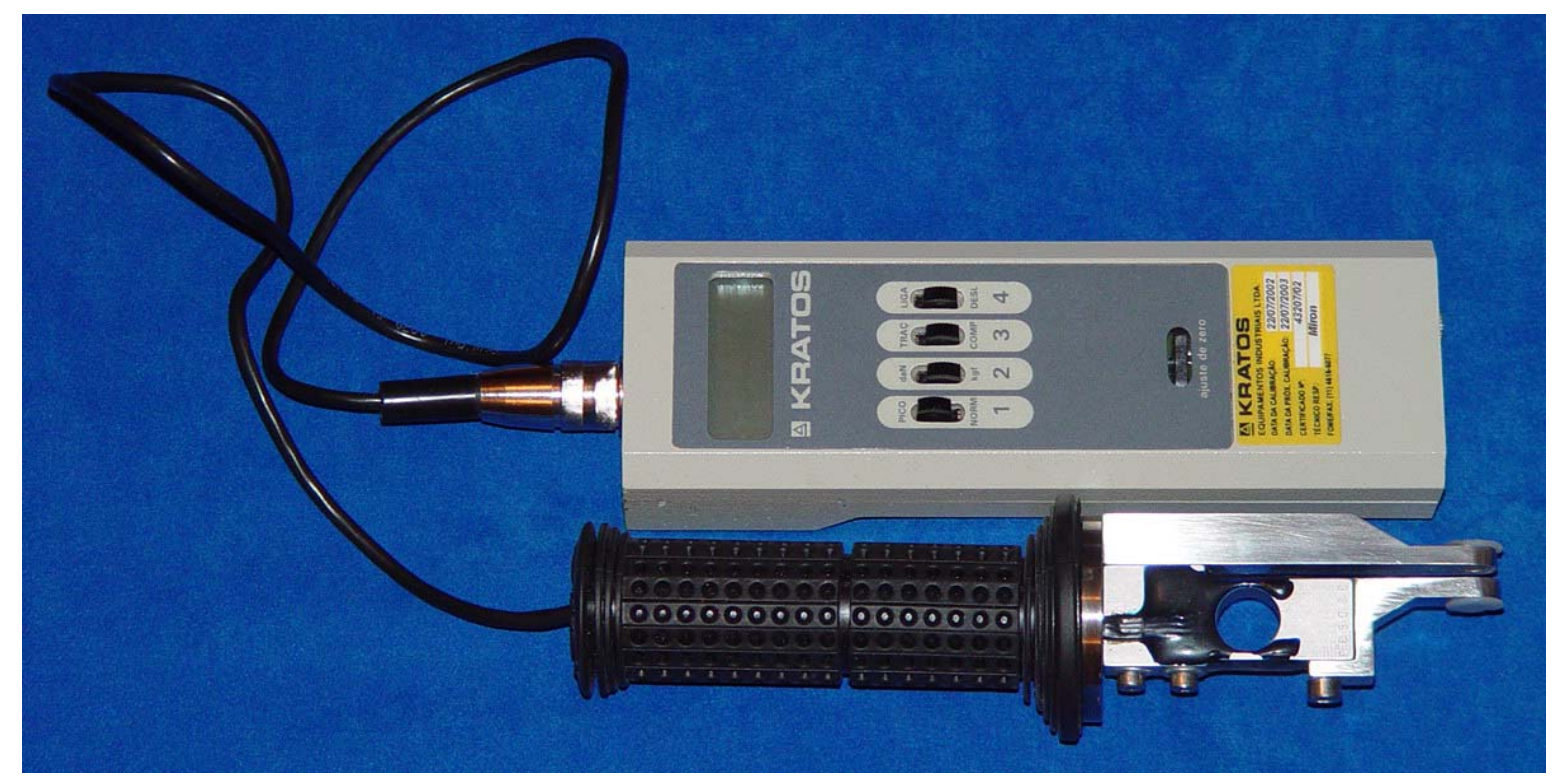

Figura 4.1. Gnatodinamômetro.

O garfo de mordida possui um comprimento total de $22 \mathrm{~cm}$, sendo $12 \mathrm{~cm} \mathrm{o}$ comprimento da haste de pega e $10 \mathrm{~cm}$ o comprimento da haste de mordida. Tal haste é formada por uma célula de carga capaz de registrar forças de compressão ou tração exercidas sobre duas hastes metálicas de $4 \mathrm{~mm}$, paralelamente dispostas e separadas por $4 \mathrm{~mm}$. Tais hastes são munidas de uma proteção plástica a fim de evitar desconforto ao paciente durante a obtenção dos registros (Figura 4.4). 


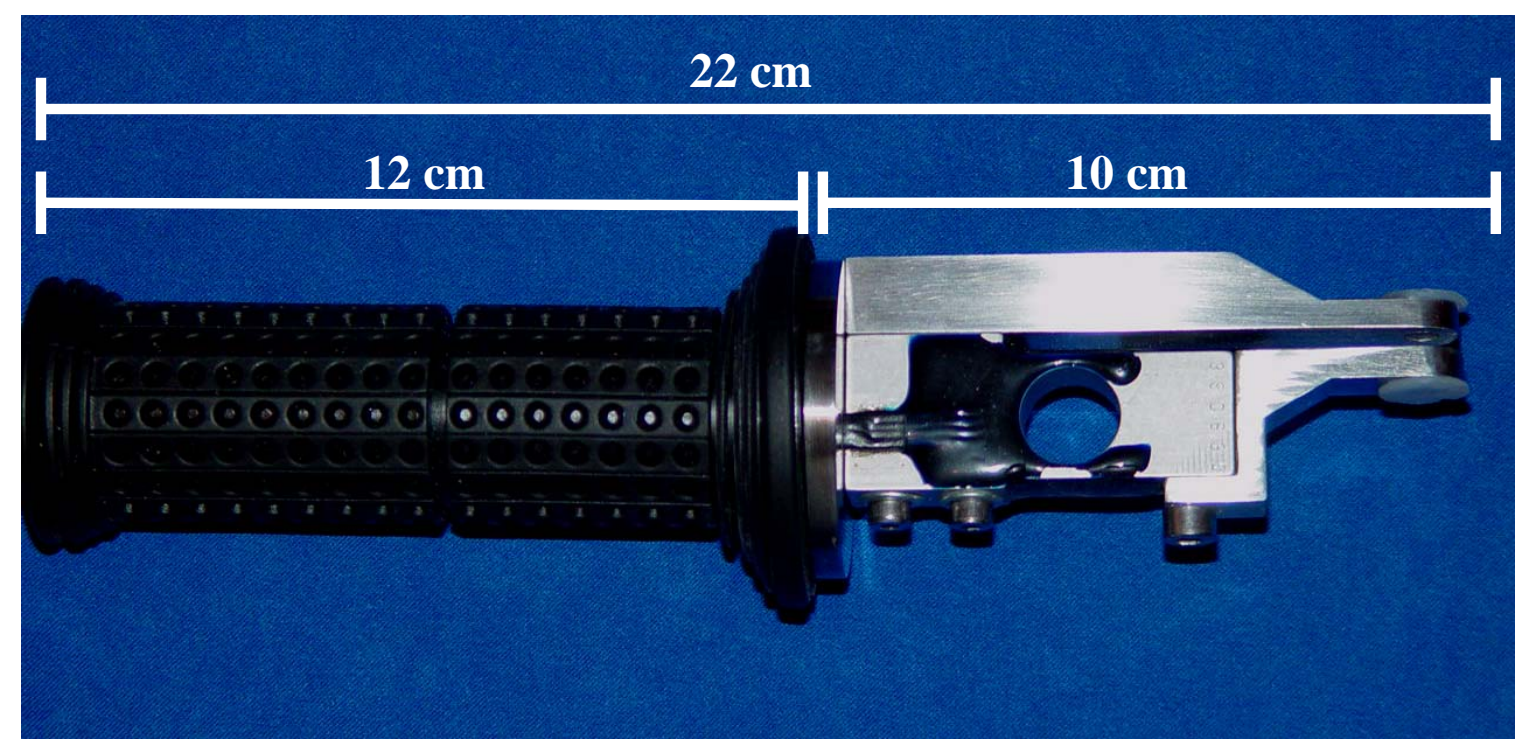

Figura 4.2. Garfo de mordida do gnatodinamômetro.

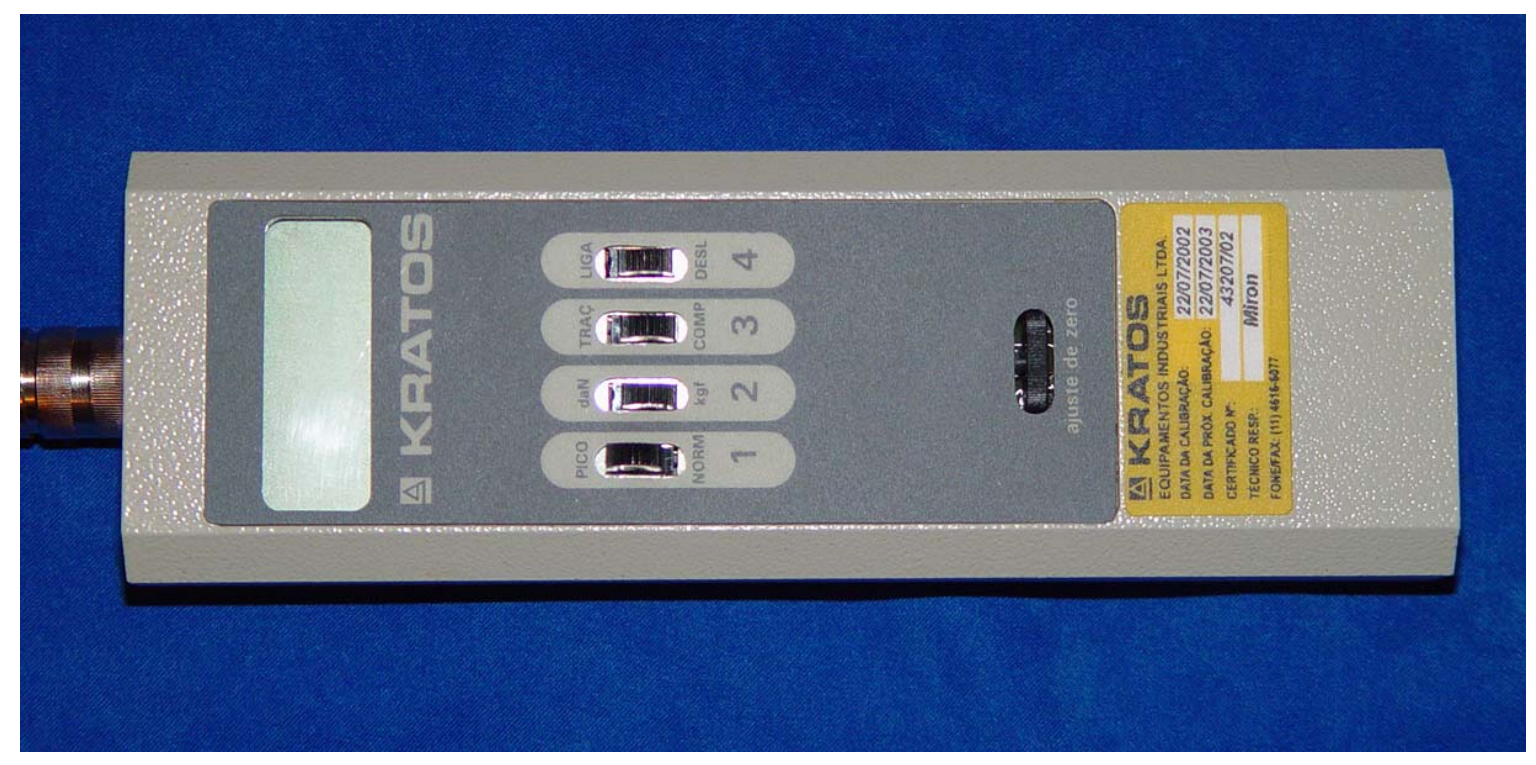

Figura 4.3. Corpo do gnatodinamômetro. 
A célula de carga de alta precisão e seu circuito eletrônico, para indicar força, fornecem medições precisas e de fácil leitura através de seu mostrador digital de cristal líquido (PELLIZER e MUENCH, 1997) ${ }^{48}$.

O corpo digital apresenta comprimento de $20 \mathrm{~cm}$, por $6,5 \mathrm{~cm}$ de largura e 4,3 cm de altura, e é composto pelo mostrador digital de cristal líquido, pelos botões de ajuste e pelo "ajuste do zero" (Figura 4.5).

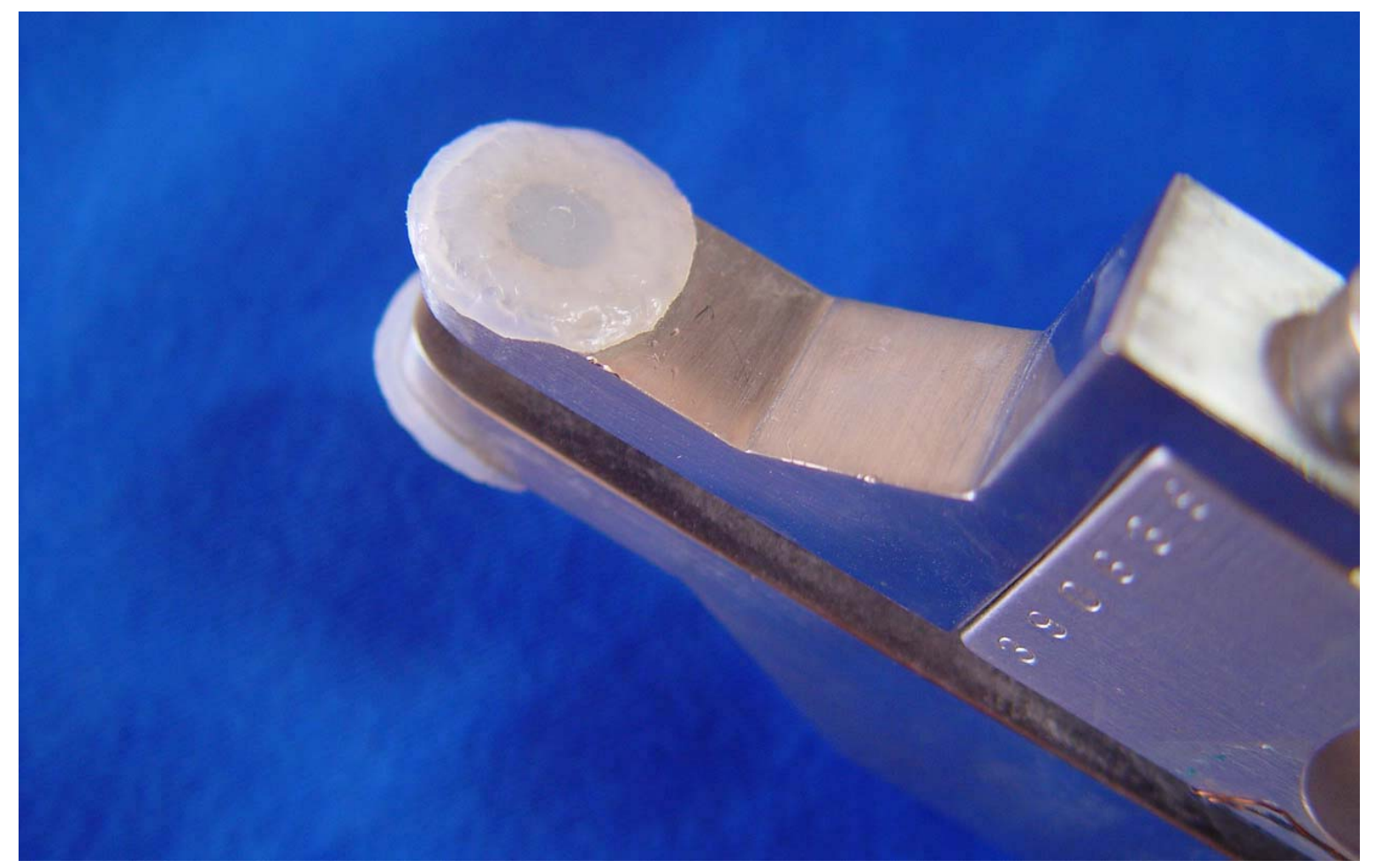

Figura 4.4. Proteção plástica do garfo de mordida do gnatodinamômetro. 
O aparelho apresenta quatro botões de ajuste, com as seguintes funções:

- "Pico" ou Normal (quando selecionada a posição "Pico", após realizada a mensuração da força, o valor máximo que foi obtido durante o esforço fica registrado e gravado (PELIZZER e MUENCH, 1997) ${ }^{48}$ );

- Unidade de força (Newton ou Kilograma/força);

- Tipo de força (tração ou compressão);

- Liga/ desliga.

A Figura 4.6 mostra os botões com as opções utilizadas nessa pesquisa.

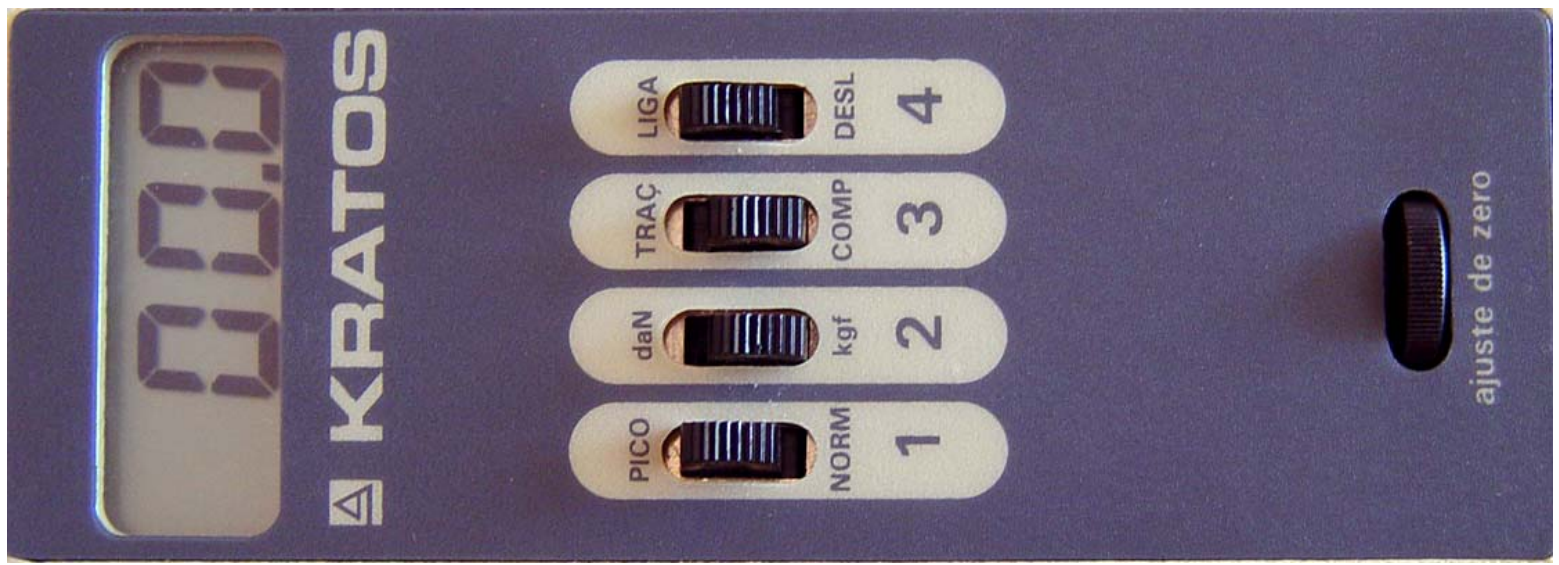

Figura 4.5. Visão aproximada do mostrador digital de cristal líquido, botões de ajuste e "ajuste do zero".

Na parte inferior do aparelho, encontra-se um botão giratório, o "ajuste de zero", que permite o ajuste do valor ZERO antes do início do ensaio, por meio da rotação do mesmo, ou seja, se antes da realização do ensaio aparecesse um valor menor que ZERO na tela, o botão era girado para a direita até que o valor 
ZERO fosse obtido, e, se o valor aparecesse maior que ZERO, o botão era girado para a esquerda até atingir o valor ZERO, controlando assim, com maior segurança, os valores de força de mordida encontrados nessa pesquisa.

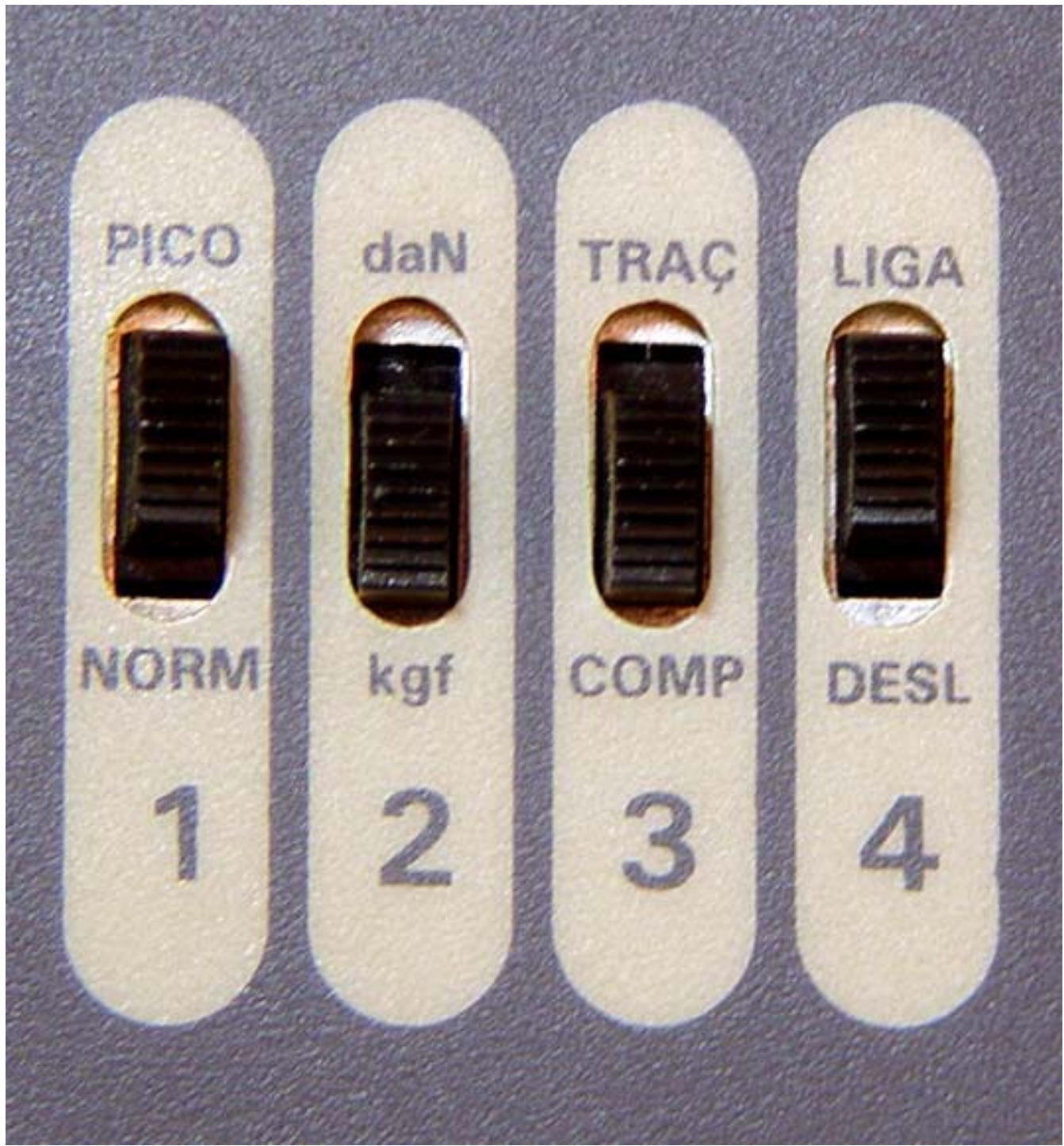

Figura 4.6. Botões de ajuste mostrando as opções utilizadas nessa pesquisa. 


\subsubsection{Preparo de paciente}

Os indivíduos eram posicionados em cadeira odontológica na posição ortostática, e recebiam orientações e treinamento prévios para se familiarizarem com o gnatodinamômetro.

Além disso, os mesmos eram estimulados a exercerem força máxima de mordida, sem, no entanto, sentir dores nem nos músculos nem nos dentes.

\subsubsection{Preparo de aparelho}

Antes de cada sessão era verificado o funcionamento do aparelho, bem como as posições dos botões, além disso, era realizado o "ajuste de zero" como descrito anteriormente.

Após isso, as hastes do gnatodinamômetro eram protegidas com dedos de luvas descartáveis (Figura 4.7), a fim de evitar qualquer possibilidade de contaminação (PELIZZER e MUENCH, 1997) ${ }^{48}$. 


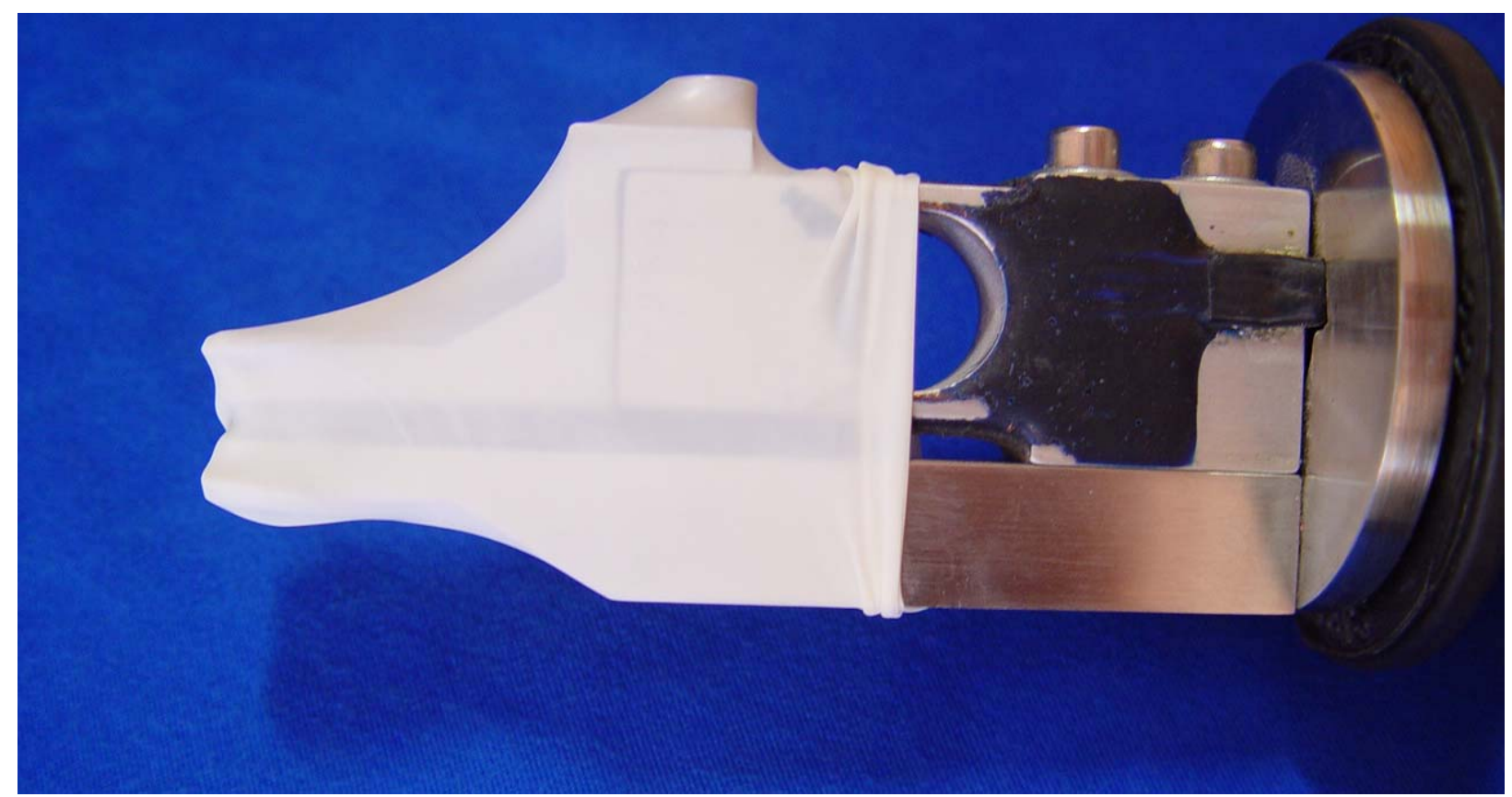

Figura 4.7. Proteção das hastes do gnatodinamômetro, com dedo de luva descartável.

\subsubsection{Obtenção dos registros}

As mensurações foram realizadas na região de primeiro molar (Figura 4.8). Duas consultas foram realizadas, com 10 dias, em média, de separação entre elas, na tentativa de evitar que mudanças de caráter psicológico, como estresse e ansiedade, pudessem interferir nos valores de força, uma vez que apenas o maior valor para cada lado foi considerado $8,22,25,28,32,33,34,44,51,55,60$ e 61 .

Em cada uma das consultas foram realizados 6 registros, sendo 3 de cada lado (direito e esquerdo). No total, doze valores de força máxima de mordida, para cada indivíduo, foram obtidos através da realização do procedimento por um único examinador durante toda a pesquisa. 
As medições eram iniciadas após orientação e familiarização com o aparelho por parte do paciente. Tais registros eram obtidos na seguinte seqüência: primeiros molares direito, primeiros molares esquerdos, e assim sucessivamente até que fossem obtidos três valores de força para cada lado. Entre cada registro havia um intervalo de 30 segundos, quando era feita a verificação da integridade do dedo de luva que protegia o aparelho, além da verificação do valor ZERO, que devia estar indicado na tela de cristal líquido.

Os valores foram armazenados de forma adequada em uma ficha desenvolvida exclusivamente para essa pesquisa (Anexo 7).

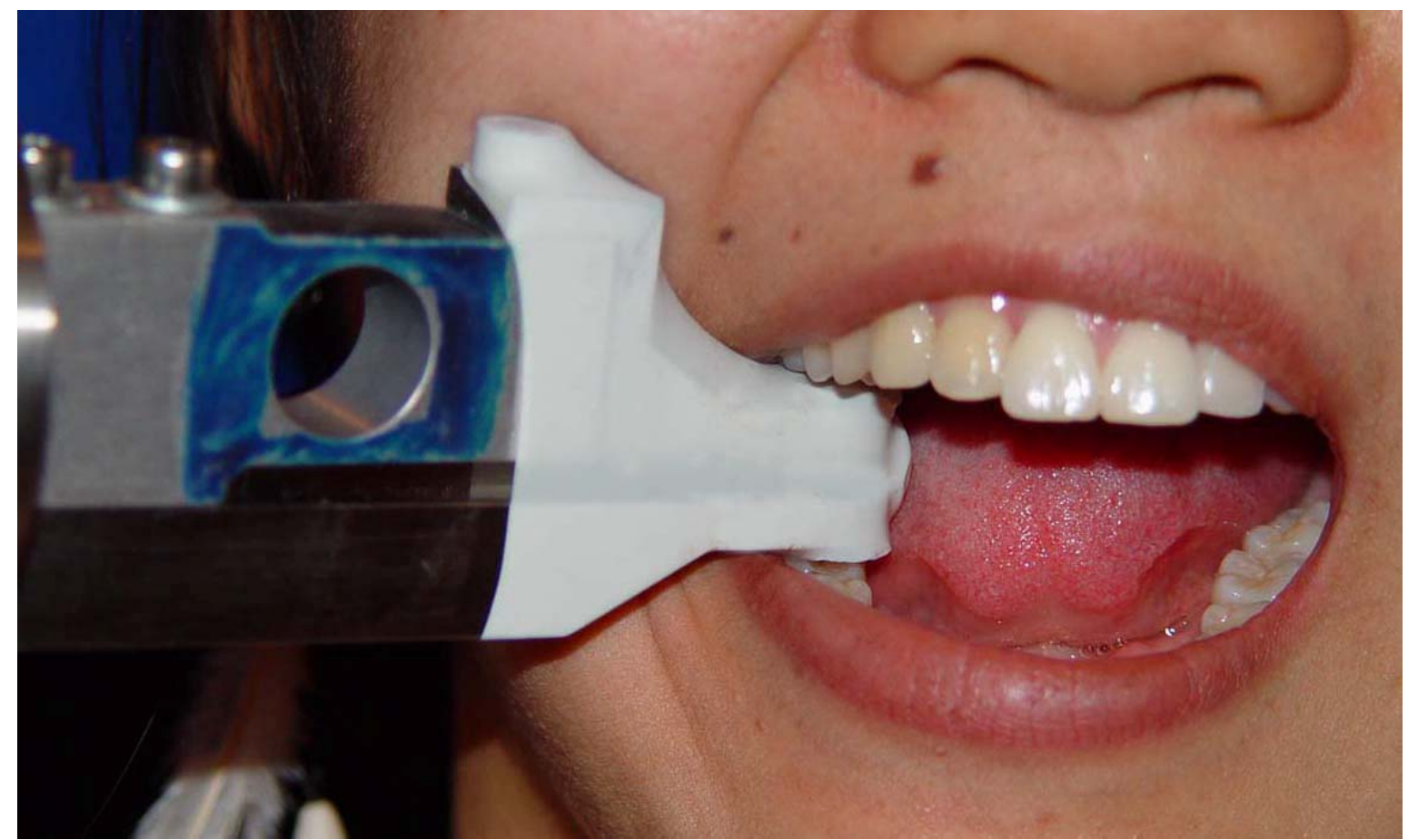

Figura 4.8. Mensuração da força de mordida sendo realizada na região de primeiro molar direito. 


\subsection{Análise estatística}

Os dados foram analisados por meio de análise de variância (ANOVA), a dois critérios (presença de bruxismo e gênero), com nível de significância de 5\%. Testes "post-hoc" foram aplicados, quando necessário.

Os diagnósticos por meio de exame físico de bruxismo (grupo experimental) ou não (grupo controle) obtidos por cada um dos três examinadores para cada um dos 120 indivíduos examinados nesta pesquisa foram avaliados quanto à concordância. Para tal, utilizou-se o teste estatístico de Kappa, seguindo os parâmetros sugeridos por LANDIS e $\mathrm{KOCH}^{29}$ em 1977. Os autores determinaram que dependendo do valor de Kappa obtido, a concordância pode ser considerada desde pobre até quase perfeita (Tabela 4.2).

Tabela 4.2. Valores de Kappa.

\begin{tabular}{|c|c|}
\hline Valor de Kappa & Concordância \\
\hline$<0,00$ & Pobre \\
\hline $0,00-0,20$ & Fraca \\
\hline $0,21-0,40$ & Considerável \\
\hline 0,41 e 0,60 & Ooderada \\
\hline 0,61 e 0,80 & Quase perfeita \\
\hline 0,81 e 1,00 & \\
\hline
\end{tabular}


5. RESULTADOS 


\section{RESULTADOS}

\subsection{Força de mordida X Gênero X Bruxismo}

Dentre os resultados de força máxima de mordida obtidos nesta pesquisa, não foi observada diferença estatisticamente significante, para um mesmo indivíduo, entre as duas sessões realizadas.

Os valores médios de força máxima de mordida, por grupo e por gênero, e respectivos desvios- padrão, estão demonstrados na Tabela 5.1.

O maior valor de força máxima de mordida do grupo controle feminino foi de $85,1 \mathrm{Kgf}$, e o menor valor foi $16,9 \mathrm{Kgf}$. Para o grupo controle masculino, tais valores foram, respectivamente, 96,1 Kgf e 34,4 Kgf. Já para os pacientes portadores de bruxismo do gênero feminino, o maior valor de força máxima foi de 66,9 Kgf, enquanto o menor valor foi $11,0 \mathrm{Kgf}$. Enquanto para o grupo experimental masculino, maiores valores foram obtidos, sendo o maior valor obtido igual a 101,9 Kgf (maior valor obtido nessa pesquisa), e o menor 26,8 Kgf.

Tabela 5.1. Médias dos valores de força máxima de mordida nos diferentes grupos e gêneros (em Kgf), e respectivos desvios- padrão.

\begin{tabular}{c|c|c|c}
\hline Grupo Gênero & Feminino & Masculino & TOTAL \\
\hline Controle & $46,32(12,78)$ & $60,16(14,87)$ & 53,24 \\
\hline Experimental & $40,34(14,12)$ & $59,60(18,93)$ & 49,97 \\
\hline TOTAL & 43,33 & 59,88 & $51,60(17,41)$ \\
\hline
\end{tabular}


As diferenças entre os valores médios de força máxima de mordida, para os gêneros e grupos, em geral, podem ser observadas nas Figuras 5.1 e 5.2.

Além disso, os valores médios de força máxima de mordida, para cada um dos sub-grupos (controle feminino, controle masculino, experimental feminino e experimental masculino), podem ser vistos na Figura 5.3.

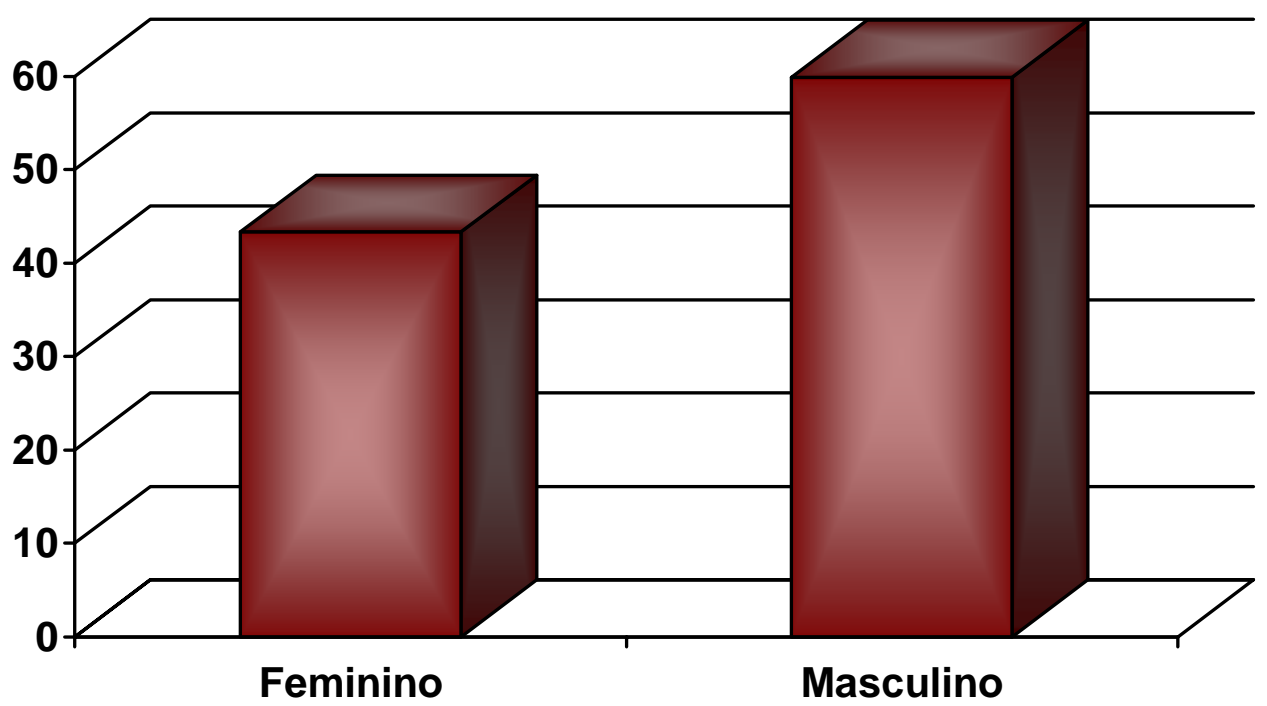

Figura 5.1. Representação gráfica dos valores médios de força máxima de mordida, de acordo com o gênero. 


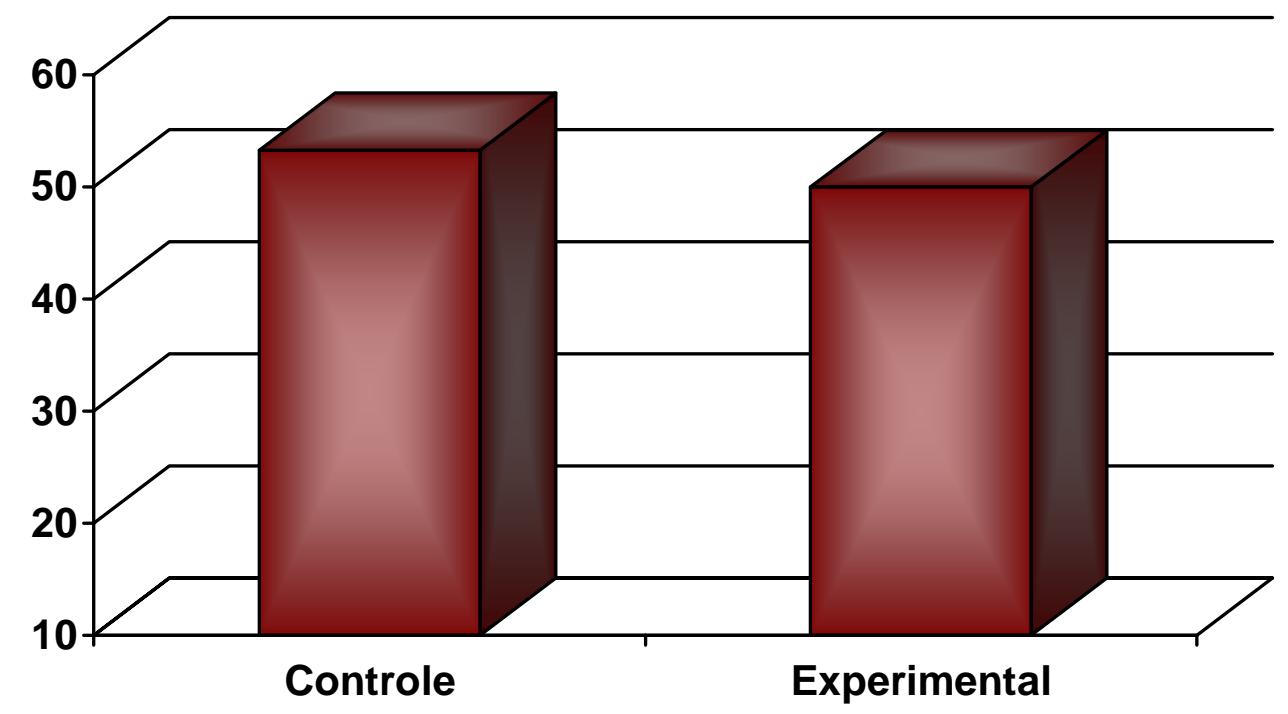

Figura 5.2. Representação gráfica dos valores médios de força máxima de mordida, de acordo com o grupo.

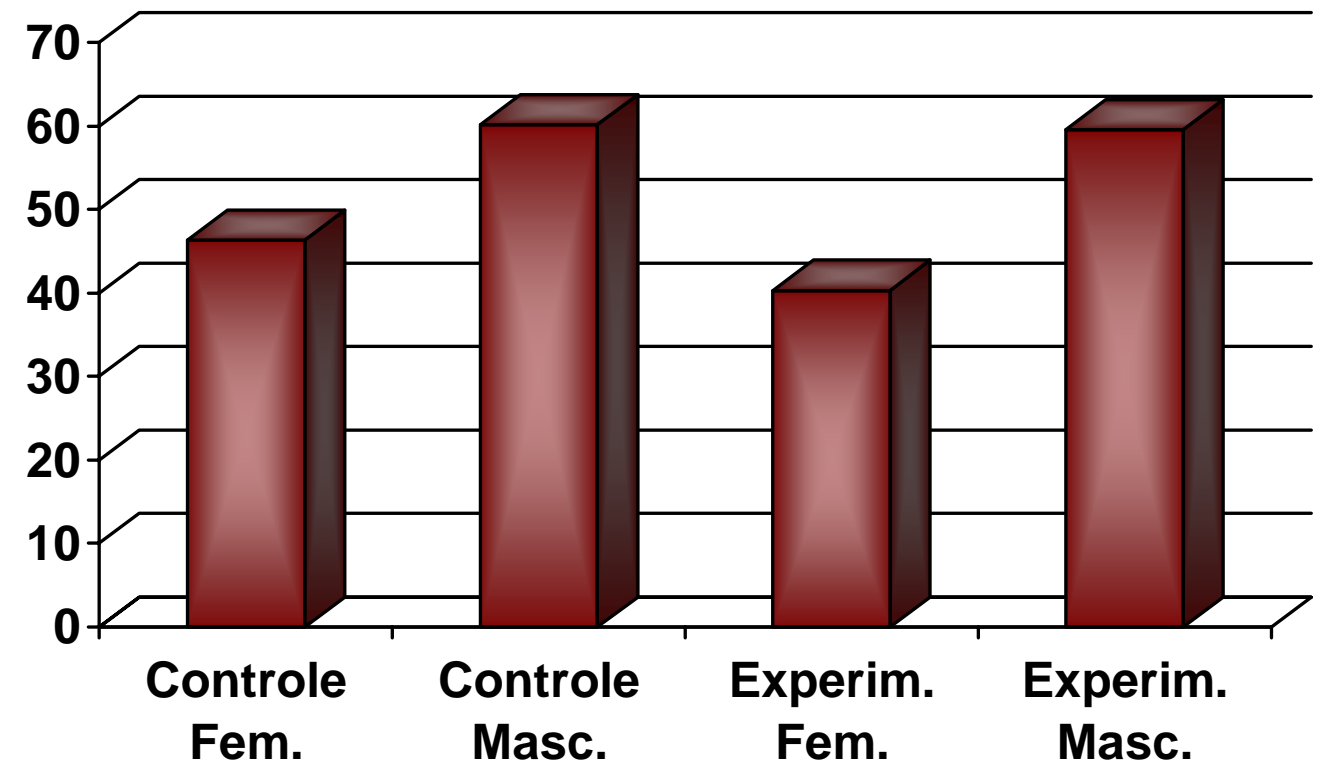

Figura 5.3. Representação gráfica dos valores médios de força máxima de mordida, de acordo com o sub-grupo. 
O teste de ANOVA a 2 critérios detectou diferença estatisticamente significante entre os gêneros $(p=0,00)$, sendo que os homens apresentaram valores de força máxima de mordida superiores aos das mulheres. No entanto, não foi observada nenhuma diferença estatisticamente significante entre os grupos controle e experimental $(p=0,25)$.

Comparando os lados direito e esquerdo não foram encontradas diferenças estatisticamente significantes, considerando grupo ou gênero $(p>0,05)$.

Comparando, isoladamente, cada um dos lados (direito ou esquerdo) em que a força de mordida foi executada, dados semelhantes foram observados, como veremos a seguir.

Para o lado direito, os valores de força máxima de mordida maior e menor, para o grupo experimental feminino, foram, respectivamente, 85,1 Kgf e 13,6 Kgf. Já no grupo controle masculino, encontrou-se, 96,1 Kgf e 34,4 Kgf, respectivamente para força máxima maior e menor. Nas mulheres do grupo experimental, o maior valor de força máxima foi de $63,9 \mathrm{Kgf}$, enquanto o menor valor foi $11,0 \mathrm{Kgf}$. Nos homens do grupo experimental, o maior valor obtido foi igual a 101,9 Kgf (maior valor obtido nessa pesquisa), e o menor 23,9 Kgf.

Os valores médios de força máxima de mordida e seus desvios padrão, para o lado direito, podem ser observados na Tabela 5.2, assim como a representação gráfica de tais valores é notada na Figura 5.4. 
Tabela 5.2. Médias e desvios padrão, aproximados, dos valores de força máxima de mordida, do lado direito, nos diferentes grupos (valores em Kgf).

\begin{tabular}{c|c|c}
\hline Grupo & Força Máxima & Desvio Padrão \\
\hline Controle Feminino & 44,84 & 13,38 \\
\hline Controle Masculino & 57,82 & 14,95 \\
\hline Experimental Feminino & 38,45 & 13,02 \\
\hline Experimental Masculino & 56,07 & 18,58 \\
\hline Todos os grupos & 49,29 & 16,98 \\
\hline
\end{tabular}

O teste de ANOVA detectou apenas diferença estatisticamente significante entre os gêneros $(p=0,00)$, sendo que, da mesma maneira, os grupos masculinos apresentaram médias de força máxima de mordida direita superiores às dos grupos femininos. Ainda, na comparação entre grupos, igualmente, não foi observada nenhuma diferença estatisticamente significante entre os grupos controle e experimental $(p=0,14)$. 


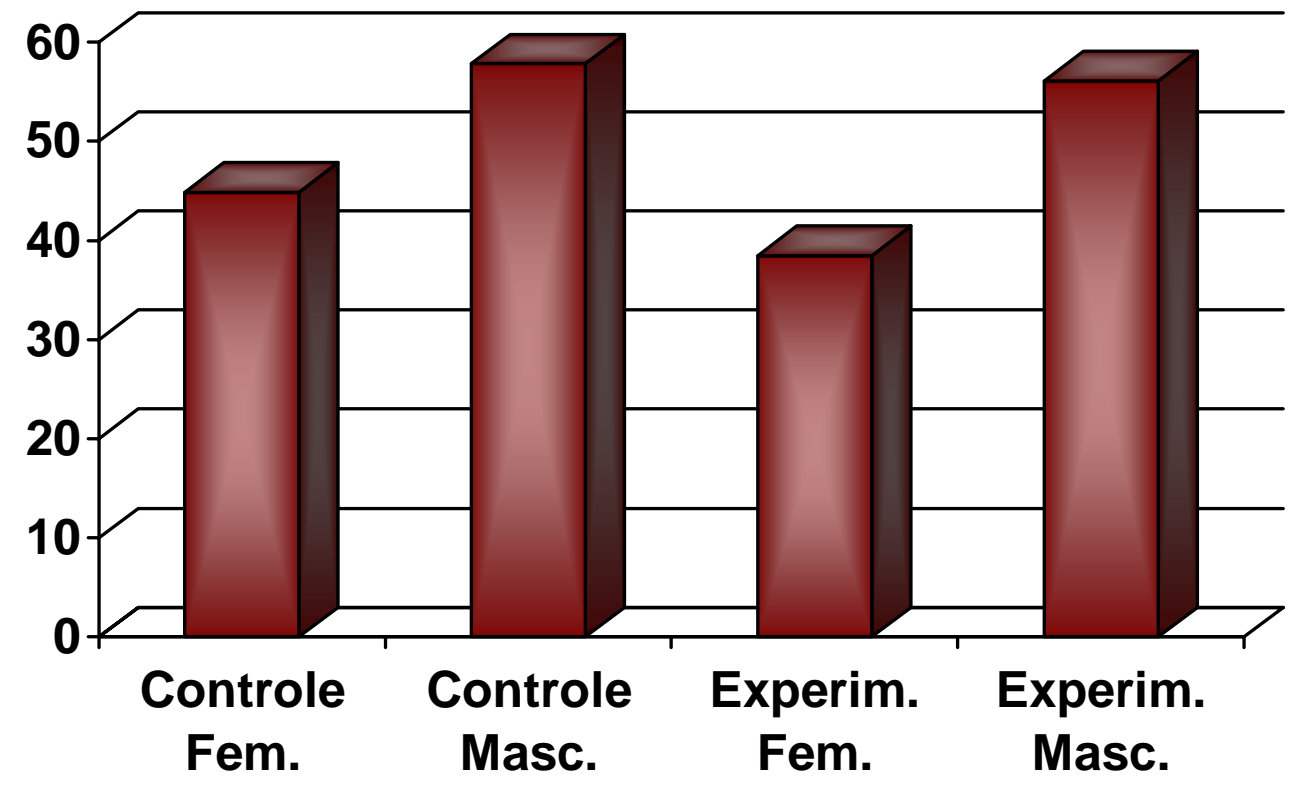

Figura 5.4. Representação gráfica dos valores médios de força máxima de mordida, para o lado direito, de acordo com o grupo.

Ainda, no lado esquerdo, para o grupo controle feminino, o maior valor de força de mordida foi de 82,3 Kgf, e o menor valor foi 16,9Kgf. Para o grupo controle masculino, tais valores foram, 96,0 Kgf e 26,8 Kgf, respectivamente. Para as pacientes portadores de bruxismo, o maior valor de força máxima foi de 66,9 Kgf e o menor valor foi $8,8 \mathrm{Kgf}$ (menor valor obtido nessa pesquisa). Já para o grupo experimental masculino o maior valor obtido igual a 98,0 Kgf, e o menor $25,4 \mathrm{Kgf}$.

Novamente os valores médios de força máxima de mordida e seus desvios padrão, agora para o lado esquerdo, podem ser observados nas representações da Tabela 5.3, assim como na Figura 5.5. 
Tabela 5.3. Médias e desvios padrão, aproximados, dos valores de força máxima de mordida, do lado esquerdo, nos diferentes grupos (valores em Kgf).

\begin{tabular}{c|c|c}
\hline Grupo & Força Máxima & Desvio Padrão \\
\hline Controle Feminino & 43,78 & 12,84 \\
\hline Controle Masculino & 56,82 & 14,95 \\
\hline Experimental Feminino & 37,60 & 14,80 \\
\hline Experimental Masculino & 57,38 & 19,67 \\
\hline Todos os grupos & 48,89 & 17,75 \\
\hline
\end{tabular}

Observou-se também que, do mesmo modo, houve apenas diferença estatisticamente significante entre os gêneros $(p=0,00)$, sendo que os grupos masculinos apresentaram médias de força máxima de mordida superiores às dos grupos femininos. E na comparação entre grupos, nenhuma diferença estatisticamente significante entre os grupos controle e experimental foi detectada $(p=0,33)$. 


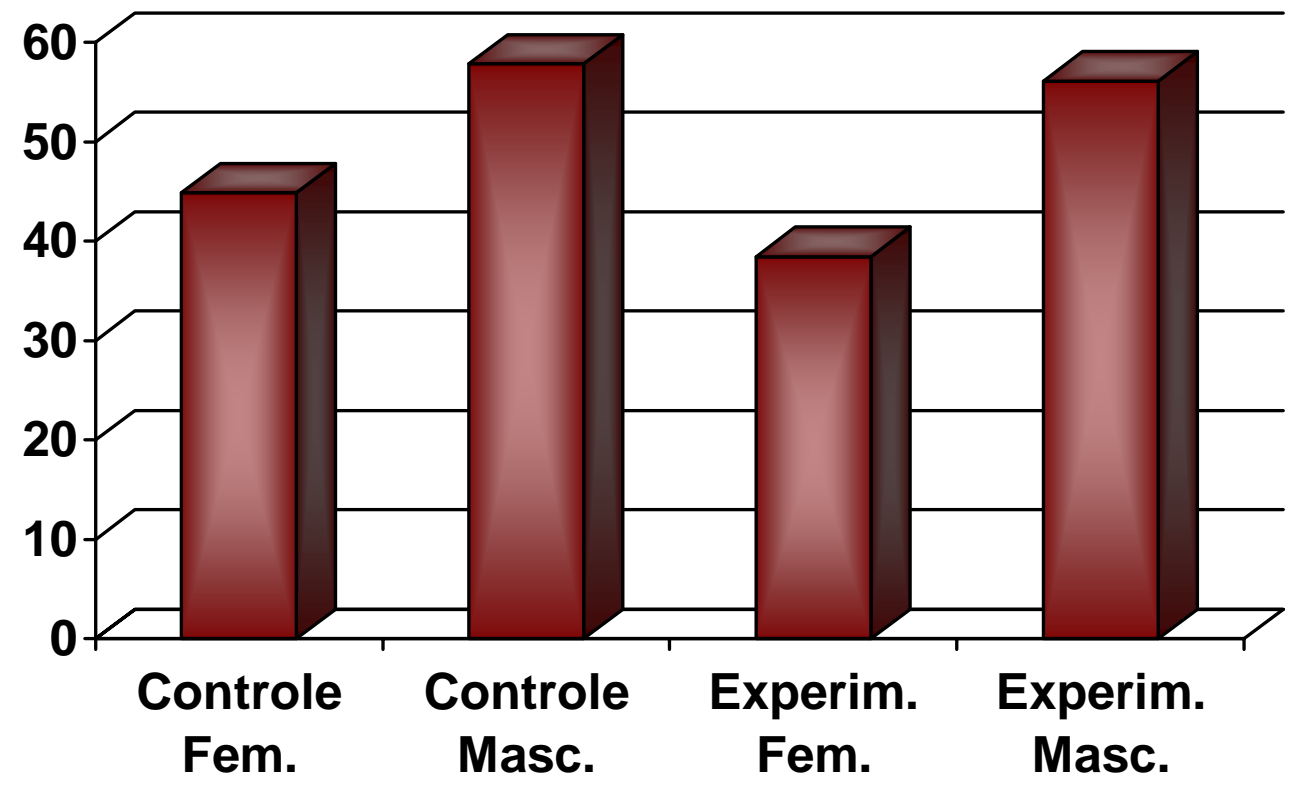

Figura 5.5. Representação gráfica dos valores médios de força máxima de mordida, para o lado esquerdo, de acordo com o grupo.

\subsection{Gênero X Hábitos}

Como foi descrito na metodologia desta pesquisa, durante o exame inicial, os pacientes eram questionados sobre possíveis hábitos parafuncionais (ranger ou apertar os dentes, onicofagia, mascar chicletes e utilizar telefone ou computador com muita freqüência), sendo que os hábitos de ranger ou apertar os dentes são indicativos de bruxismo.

Com base nas respostas (afirmativa ou negativa) relacionadas aos hábitos, realizou-se uma nova comparação entre gêneros, a fim de avaliar se tais quesitos poderiam ou não influenciar nos resultados de força máxima de mordida obtidos. 
Para isso, foi aplicado o teste de análise de variância a 2 critérios (gênero e hábito) para cada um dos itens acima citados.

Assim encontrou-se que houve diferença estatisticamente significante apenas para o hábito de mascar chicletes $(p=0,00)$, que foi mais comum entre as mulheres. Já para todos os outros hábitos nenhuma diferença estatisticamente significante foi encontrada.

A Tabela 5.4 demonstra a porcentagem de indivíduos que responderam afirmativamente para cada um dos hábitos, tanto para o gênero feminino quanto para o masculino, e ainda mostra os valores de $\mathbf{p}$ encontrados para cada comparação.

Ainda, as porcentagens de respostas "sim" e "não", para o gênero feminino, podem ser observadas através de representação gráfica na Figura 5.6, assim como, tais valores, para o gênero masculino, foram expressos na Figura 5.7. 
Tabela 5.4. Porcentagem de indivíduos portadores de hábitos, para os gêneros feminino e masculino.

\begin{tabular}{cccc}
\hline Hábito ou DTM & Feminino & Masculino & $\mathbf{p}$ \\
\hline Ranger & 35,00 & 38,33 & 0,70 \\
\hline Apertar & 65,00 & 51,67 & 0,14 \\
\hline Roer unhas & 25,00 & 30,00 & 0,54 \\
\hline Mascar chiclete & 38,33 & 15,00 & $0,00^{\star}$ \\
\hline Telefone & 23,33 & 10,00 & 0,17 \\
\hline Computador & 25,00 & 36,67 & 0,17
\end{tabular}

* diferença estatisticamente significante 


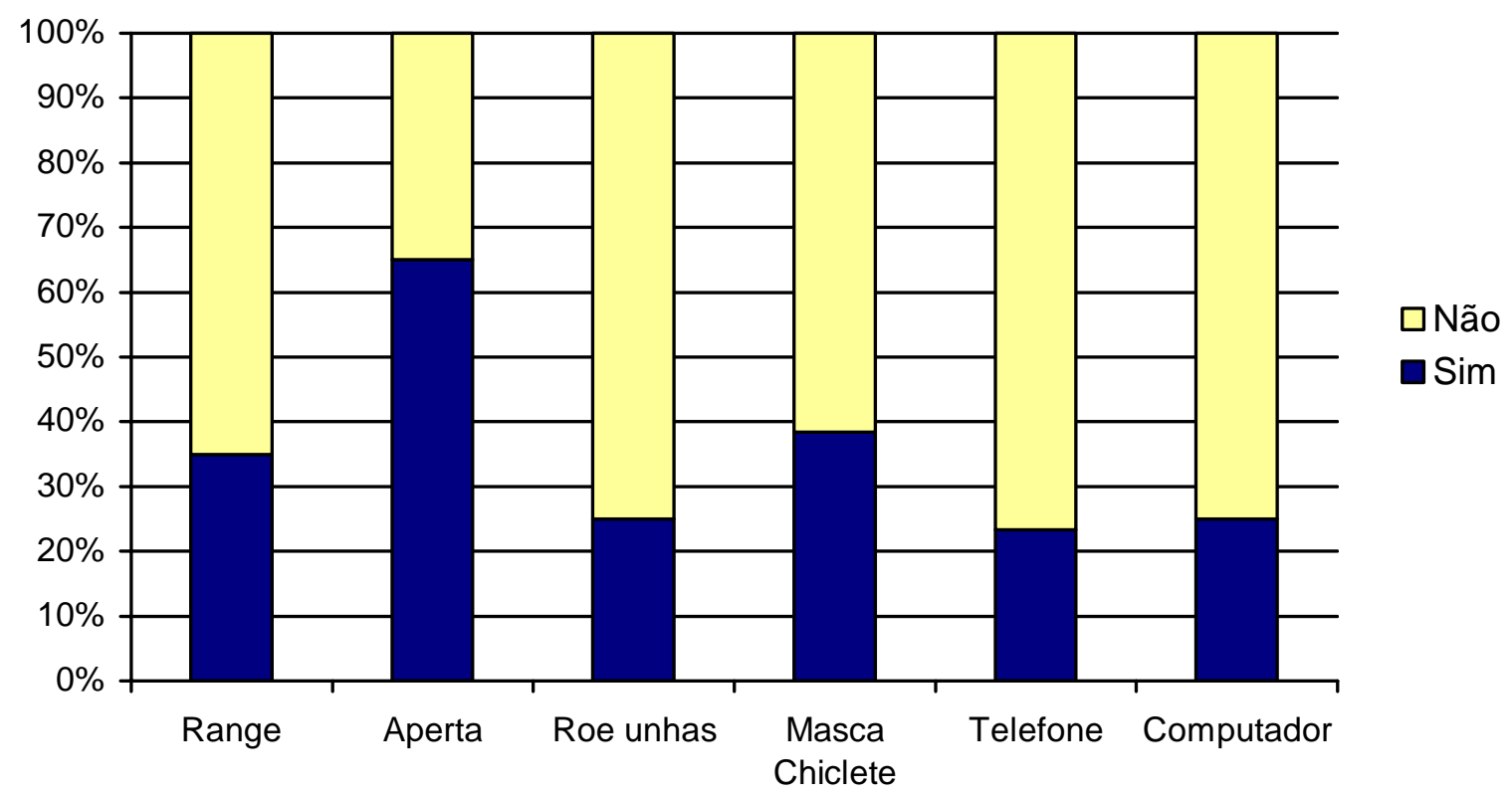

Figura 5.6. Porcentagem de indivíduos, portadores ou não de hábitos parafuncionais, do gênero feminino.

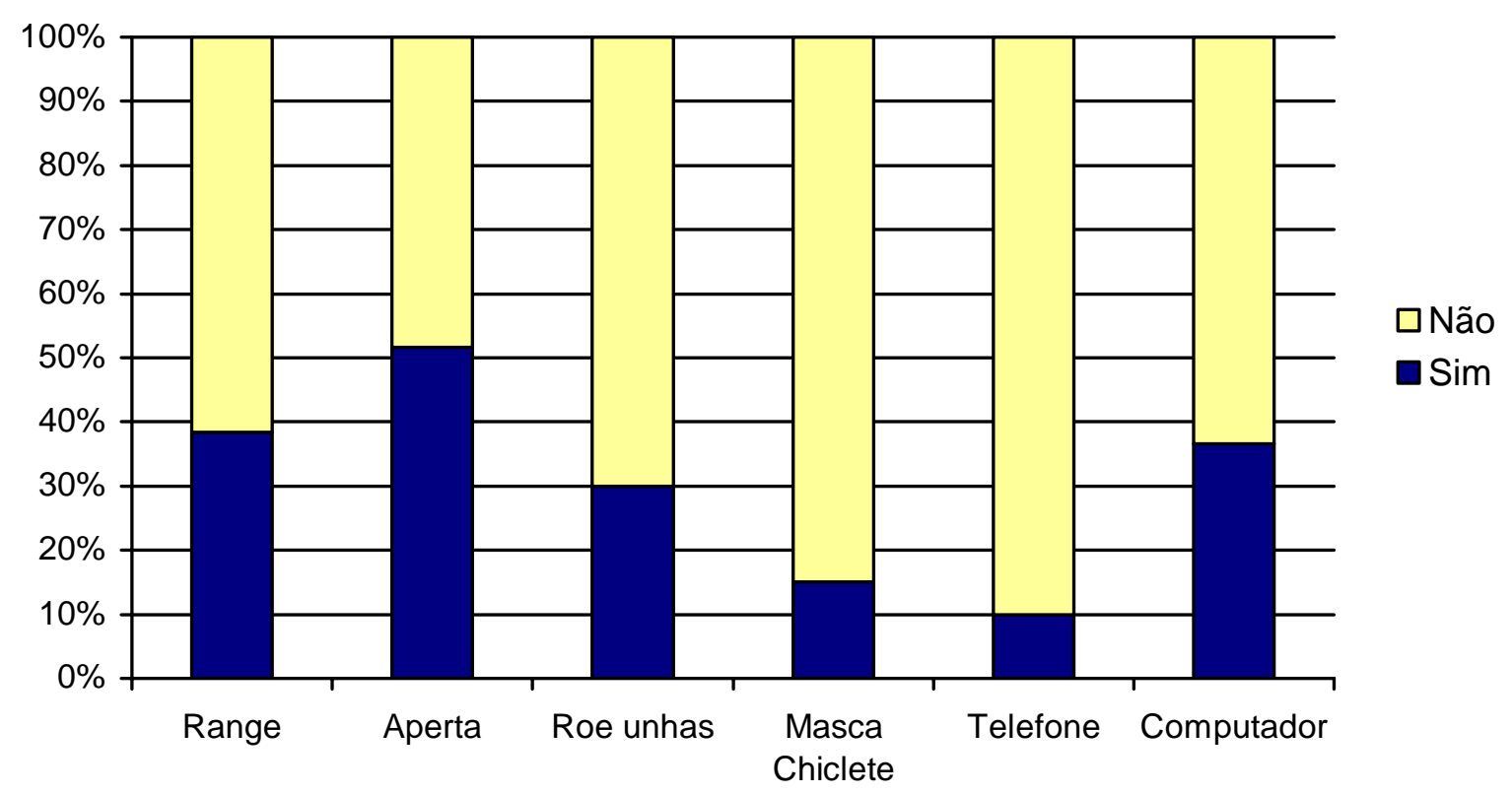

Figura 5.7. Porcentagem de indivíduos, portadores ou não de hábitos parafuncionais, do gênero masculino. 


\subsection{Concordância inter-examinadores quanto ao exame clínico de bruxismo}

Nesta pesquisa, os examinadores (designados por examinadores 1, 2 e 3), obtiveram, para o diagnóstico clínico de bruxismo, os seguintes valores de concordância de Kappa: entre os examinadores 1 e 2, encontrou-se um valor de Kappa $=0,77$, ou seja, uma concordância ótima, sendo que tais examinadores concordaram em 88,33\% dos diagnósticos (105 casos de 120). Um valor de Kappa de $K=0,64$ foi obtido entre 1 e 3, representando uma concordância ainda ótima, sendo que esses examinadores concordaram em $81,67 \%$ dos casos, o que representa uma concordância em 99 casos em 120. O valor de Kappa de 0,62, foi encontrado entre os examinadores 2 e 3 , obtendo-se novamente uma concordância ótima, tendo esses examinadores concordado em 81,67\% dos casos, o que representa, aproximadamente, 99 diagnósticos semelhantes.

A Figura 5.8 representa graficamente as porcentagens de concordâncias entre os examinadores 1 e 2, 1 e 3 e 2 e 3, e a Figura 5.9 mostra os valores de Kappa encontrados neste trabalho. 


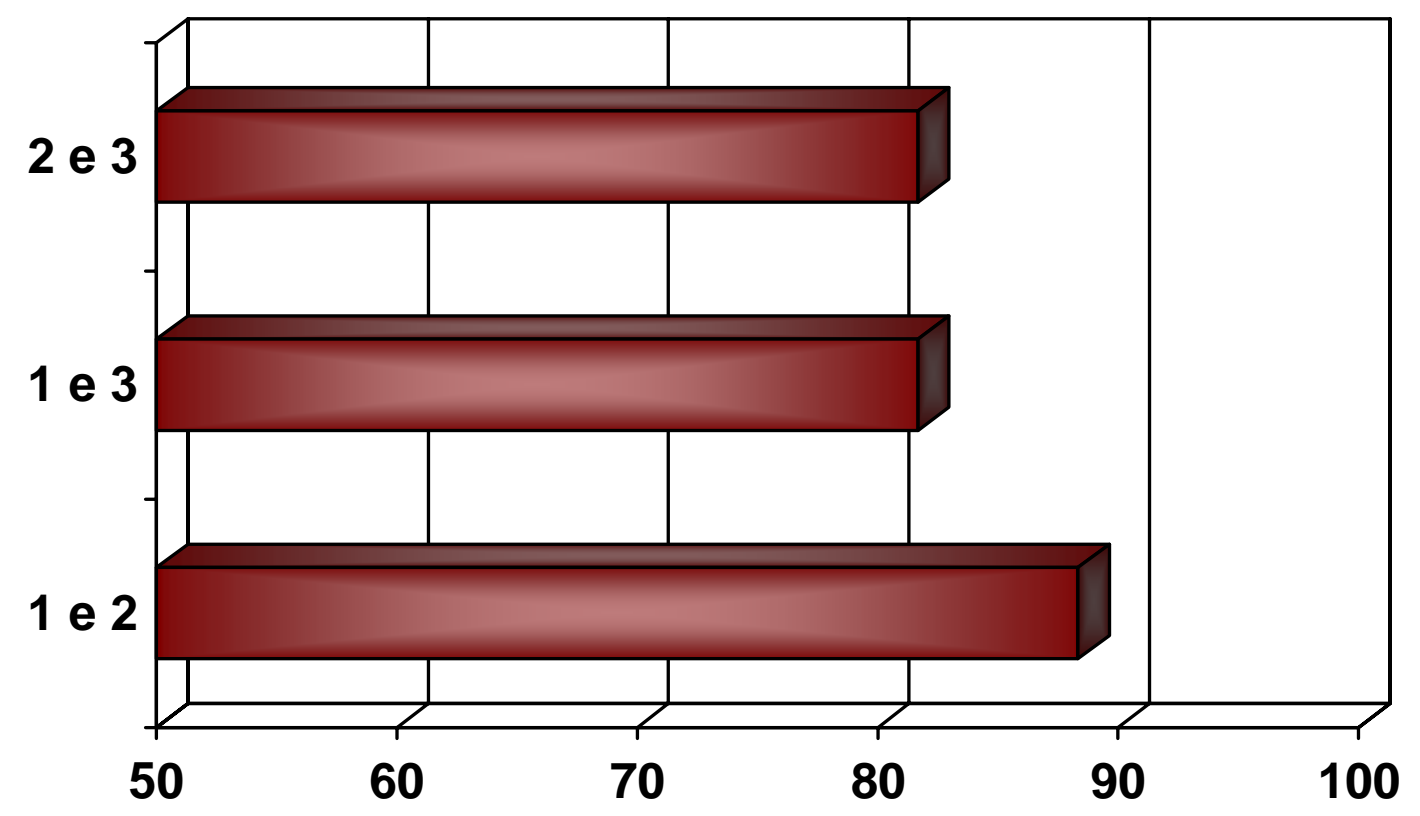

Figura 5.8. Porcentagem de concordância inter-examinadores para diagnóstico clínico de bruxismo.

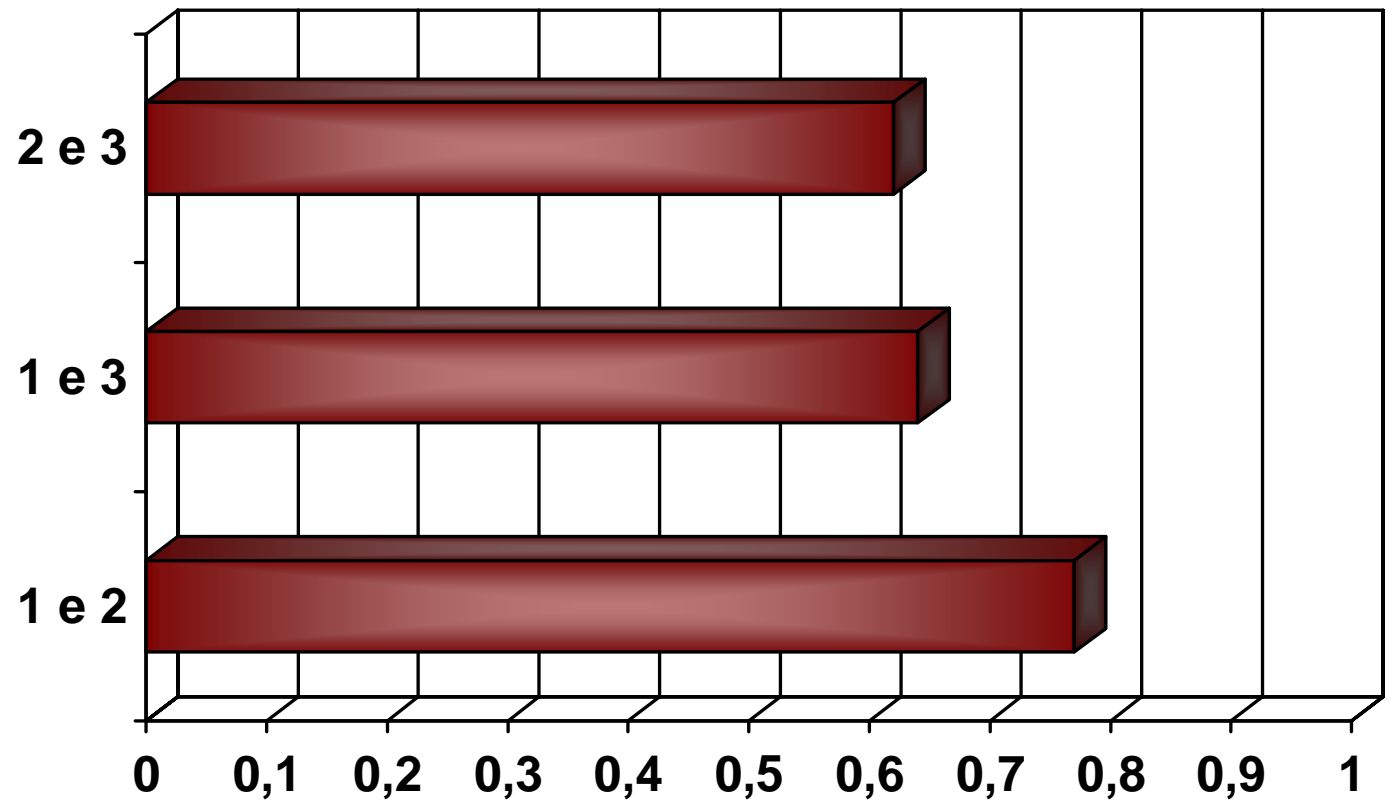

Figura 5.9. Valores de Kappa encontrados neste trabalho. 


\section{DISCUSSÃO}

\subsection{Metodologia utilizada}

A força de mordida é amplamente estudada na literatura científica, sendo relacionada a diversos aspectos, como bruxismo $2,15,34,36,38$ e 44 , hipertrofia do

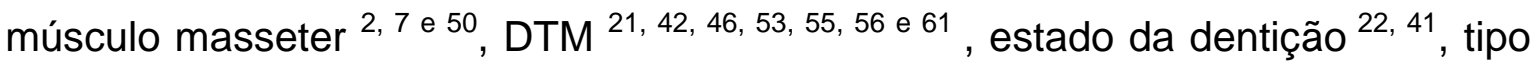
físico $^{8,32,33,51, \text { e } 61}$, morfologia facial ${ }^{25,26,28,50 \text { e } 54 \text {, estado periodontal }}{ }^{27 \text { e } 41}$, entre outros.

Além disso, o que encontra-se na literatura é uma grande diversidade de metodologias utilizadas para um mesmo fim: pesquisar a força de mordida dos indivíduos. Devido a essa grande variedade encontrada, procurou-se utilizar neste estudo, métodos baseados no que foi encontrado com maior freqüência na literatura, além de buscar-se também o que foi descrito como mais efetivo para o estudo da força de mordida.

É fácil observar na literatura a variedade de fatores relacionados ao dinamômetro utilizado, como: espessura da região de mordida, rigidez do material

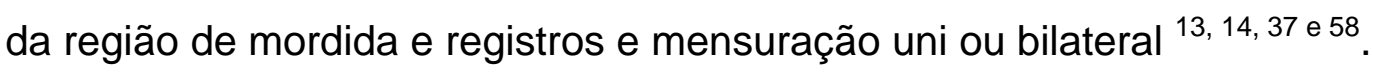

É importante ainda ressaltar que é imprescindível extremo cuidado quando se comparam os resultados obtidos por diferentes autores, principalmente devido à diversidade de aparelhos utilizados. Assim, os resultados deveriam ser comparados apenas quando o mesmo aparelho fosse utilizado (HELKIMO, CARLSSON e HELKIMO, 1976) ${ }^{22}$.

Antes de discorrer sobre os fatores acima citados, é interessante observar, ainda em relação aos dinamômetros, que alguns autores optam por equipamentos 


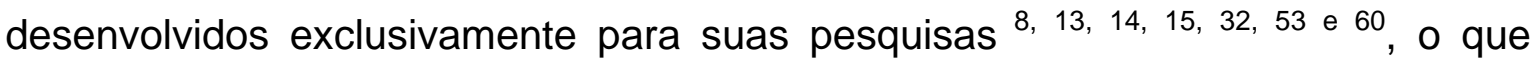
demonstra a dificuldade de comparar tais equipamentos entre si, uma vez que, até mesmo aqueles pré-fabricados diferem uns dos outros.

Nesse aspecto, um dos fatores mais estudados e controvertidos na literatura é a espessura da haste de mordida do dinamômetro. A grande diversidade de tipos pode incorrer em alterações nos resultados dos trabalhos, como observado por MANNS, MIRALLES e PALAZZI ${ }^{37}$, em 1979 e por FIELDS et al. ${ }^{14}$, em 1986.

MANNS, MIRALLES e PALAZZI ${ }^{37}$, em 1979, testaram a força de mordida em diferentes aberturas bucais e encontraram que aquela em que há menor atividade eletromiográfica e maior força, ou seja, a abertura bucal ideal para se avaliar a força máxima de mordida, foi de 18mm em média. Porém, os indivíduos estudados indicaram a abertura de $10 \mathrm{~mm}$ como a mais confortável, sendo essa abertura obtida pela medida da distância entre as faces distais dos caninos. No presente estudo, em que foi utilizado um gnatodinamômetro munido de uma haste de mordida de $12 \mathrm{~mm}$ de espessura, o valor de abertura bucal foi de aproximadamente $16 \mathrm{~mm}$, ou seja, bem próximo da abertura ideal encontrada pelos autores.

Em 1986, FIELDS et al. ${ }^{14}$ testaram a influência da abertura bucal na força de mordida na região de $1^{\circ}$ molar e encontraram que a força máxima de mordida tem valor crescente até $20 \mathrm{~mm}$ de abertura (medida realizada entre os incisivos), e, a partir dessa abertura esse valor decresce, sendo, portanto essa a abertura a ideal. No presente estudo, através da utilização do gnatodinamômetro digital, modelo IDDK (Kratos Equipamentos Industriais Ltda, Cotia, SP), esse valor foi de 
aproximadamente $18 \mathrm{~mm}$, estando novamente próximo ao valor de abertura de incisivos ideal para avaliar a força máxima de mordida.

Outro fator de estudo na literatura é a influência da rigidez do material da região de mordida do gnatodinamômetro, que foi estudada em 2003 por FERNANDES et al. $^{13}$. Os autores desenvolveram um sensor de silicone e o compararam com um convencional (metálico), e encontraram que, apesar de mais confortável para os indivíduos, o sensor de silicone teve registro de valores de força semelhantes aos do sensor metálico. Neste estudo, a opção por um sensor metálico, munido de uma proteção plástica, foi devida ao fato de ser o mais comumente testado e utilizado na literatura, apresentando, portanto, maior respaldo científico para sua utilização.

Além disso, foram encontrados na literatura relatos de transdutores

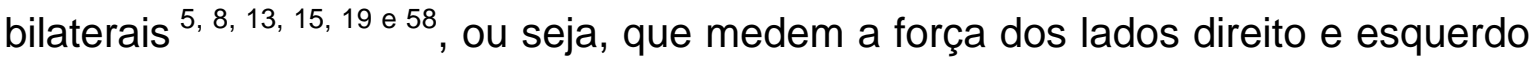
ao mesmo tempo, assim como de transdutores unilaterais $1,7,13,14,20,21,22,25,26,27$, $28,32,33,34,37,42,44,46,53,54,57,58,60$ e 61 , que medem a força de um lado de cada vez, e dois dos estudos que comparam a utilização de transdutores uni ou bilaterais ${ }^{14}$ e 58

No estudo de FIELDS et al. ${ }^{14}$, em 1986, os autores avaliaram a influência de um suporte contra-lateral no momento da mensuração da força de mordida. Encontraram que as medidas de força não foram afetadas pelo suporte contralateral, ou seja, a presença de suporte contra-lateral nos transdutores bilaterais não deve ser considerada uma vantagem de tal método.

Em 1998, TORTOPIDIS et al. ${ }^{58}$ compararam 3 diferentes transdutores de força de mordida, sendo um unilateral, um bilateral e um anterior. Com base nos 
resultados obtidos, os autores concluíram que a força máxima de mordida é mais bem reproduzida quando se lança mão de um aparato unilateral posterior, uma vez que tal aparato é o que apresenta menores variações para um mesmo indivíduo. Esse achado fortalece a confiabilidade deste estudo, no qual utilizou-se um gnatodinamômetro unilateral posterior, que é um método confiável e simples ${ }^{18}$ e 47

Outro fator discutível é a descrição da força mensurada, a localização do registro, assim como, o número de sessões realizadas.

Nos trabalhos que utilizam diferentes meios de mensurar a intensidade de

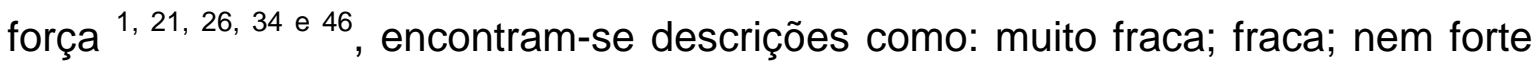
nem fraca; forte; como se estivesse mordendo um sanduíche; força de mastigação; leve e máxima. Assim, pode-se considerar que, exceto quando solicita-se a força máxima, as outras descrições são extremamente subjetivas, uma vez que as forças fraca, forte e leve podem ter magnitudes bem diferentes entre os indivíduos, o que, obviamente, dificulta a análise dos resultados. Essa afirmação parece ser real, pois dos trabalhos revisados para esta pesquisa, o que por último utilizou-se de diferentes intensidade de força de mordida em sua metodologia foi o de KILIARIDIS et al. $^{26}$, em 1995, demonstrando que as pesquisas mais atuais descartaram a intensidade da força como sendo um fator importante, muito provavelmente por ser um fator extremante particular para cada indivíduo. Portanto, nesta pesquisa optou-se em estudar apenas a força máxima de mordida dos indivíduos, no intuito de excluir fatores subjetivos que pudessem, de alguma forma, alterar os resultados obtidos. 
Outro fator que é encontrado indistintamente na literatura é a região onde é realizada a mensuração da força de mordida. Alguns autores fazem essa

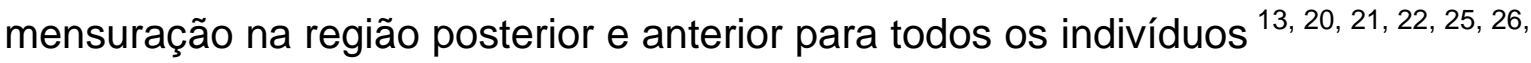
$28,32,37,46,53,58,57,60$ e 61 , outros realizam tal procedimento apenas na região anterior $2,36,38,50$ e 56 e, assim como nesta pesquisa, alguns autores avaliam apenas a força de mordida na região posterior 1 , 5, 7, 8, 10, 14, 15, 19, 27, 33, 34, 42,44, 54 e 55 .

Em 1990, LYONS e BAXANDALE ${ }^{36}$ discutiram o fato de que a realização de mensurações de força em posições excêntricas (protrusão, lateralidade) pode ser complicada, pois é quase impossível atingir o mesmo grau de excentricidade, ainda que em um mesmo indivíduo. É claro que quando a força é mensurada nos dentes posteriores, os indivíduos, na maioria das vezes, não conseguem manter uma relação oclusal habitual durante os esforço. Alguns tendem a executar algum grau de movimento lateral, porém, sem interferir com o resultado. Quando a força é mensurada entre os caninos, os indivíduos tendem a desviar a mandíbula para a posição de lateralidade, e, quando a força é mensurada entre os incisivos, os indivíduos tendem a executar tal força em uma posição excêntrica protruída ${ }^{36}$.

Na tentativa de atenuar tal fator desvantajoso, os indivíduos desta pesquisa foram submetidos a fatores de exclusão (ausência de dois ou mais dentes, utilização de prótese dental removível, presença de má-oclusão grosseira) e inclusão (presença de todos os primeiros molares na boca, íntegros ou restaurados) na tentativa de padronizar as características oclusais, minimizando assim os riscos de obter-se resultados não reprodutíveis.

Em 1993, WALTIMO e KONONEN ${ }^{60}$, questionaram o fator limitante da força de mordida durante a mensuração, e encontraram que na região posterior o 
principal fator limitante foi o limite da força muscular, enquanto na região anterior foi a dor nos dentes. Os autores afirmaram que a força na região posterior representa melhor o potencial muscular máximo do indivíduo, uma vez que é limitada pela insuficiência de força muscular. Já na região anterior, são os dentes e ligamento periodontal que exercem a função moderadora da força de mordida.

Diversidade também é encontrada quando se discute em qual dente posterior o registro da força será realizado. Alguns autores ${ }^{1,8,9,15 \text { e } 27}$ realizaram a mensuração na região de prés-molares e molares, simultaneamente, principalmente devido à largura do garfo de mordida que não possibilita a mensuração apenas em um dente. Outros autores optaram por medir a força na

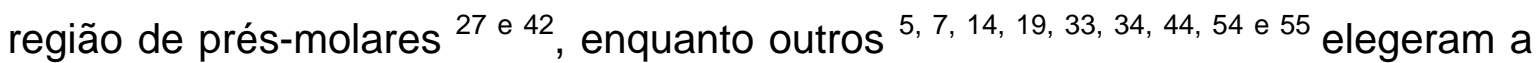
região de primeiros molares para tal. Nesta pesquisa foi selecionada a região de primeiros molares por ter sido a região mais comumente avaliada e testada na literatura.

O último fator de discussão quanto à força de mordida é o número de sessões. Independente da quantidade de retornos realizados, persiste a controvérsia em relação à necessidade de mensurar a força de mordida em diferentes ocasiões para evitar algum tipo de alteração no resultado devido ao estado do indivíduo. Aspectos como estresse, depressão e condições sistêmicas podem alterar a força de mordida.

Esses fatores foram avaliados por TORTOPIDIS et al. ${ }^{58}$, em 1998 que estudaram a força de mordida com diferentes transdutores em diferentes ocasiões (3 sessões, intercaladas por uma semana). Os autores não encontraram diferenças entre os resultados obtidos nas três diferentes ocasiões. No presente 
estudo, no entanto, optou-se por utilizar duas sessões intercaladas por 10 dias, em média, baseado na afirmação de HELKIMO, CARLSSON e CARMELI ${ }^{21}$, em 1975, na qual os autores alegam que as proximidades entre os valores obtidos na primeira e segunda sessão fortalecem a segurança do método.

Ainda, dentro da discussão da metodologia utilizada, outro fator variável é qual valor deve ser utilizado como resultado. O que se observa, neste aspecto, é que a maioria dos trabalhos utiliza o valor máximo encontrado para cada região

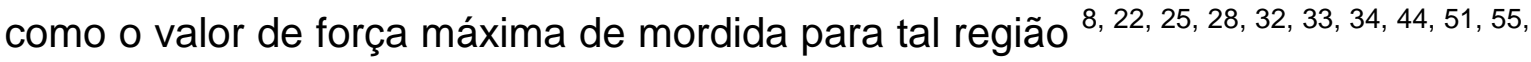
60 e 61 . Porém, existem outros autores que optam por realizar a média dos valores de força para cada região 7, 19, 26, 27, 42, 50 e 54 .

Neste tópico, preferiu-se utilizar o maior valor, assim como a maioria das pesquisas, não só por praticidade e segurança (pois tal método já foi bastante utilizado), mas também porque o objetivo desta pesquisa foi avaliar a força máxima de mordida, portanto, o maior valor encontrado certamente seria aquele que se encontra o mais próximo da força máxima de mordida do indivíduo.

Ainda dentro da metodologia aplicada, o fator de critério de inclusão pelo diagnóstico clínico de bruxismo é um fator controvertido, como pode ser observado nos critérios de inclusão utilizados em algumas pesquisas ${ }^{15,34 \text { e } 59}$.

A respeito disso, LINDQVIST e RINGQVIST ${ }^{34}$, em 1973, empregaram como critério de inclusão para o grupo de bruxômanos a presença de facetas de desgaste coincidentes.

Ainda, GIBBS et al. ${ }^{15}$, em 1986, classificaram como bruxômanos, em sua pesquisa, os indivíduos que apresentaram facetas de desgaste, bem como hipertrofia dos músculos masséter e temporal. 
Em 1999, YOUNG et al. ${ }^{59}$, classificaram como bruxômanos os indivíduos portadores de facetas de desgaste em, no mínimo, 90\% dos dentes, com história de apertar ou ranger os dentes, com fadiga ou sensibilidade na ATM ou músculos e presença de dores de cabeça.

Assim como nesta pesquisa, MANTYVAARA et al. ${ }^{38}$, em 1999, diagnosticaram o bruxismo através de exame físico e questionário. Porém aqui, a escolha do exame físico e questionário, que determinaram a presença ou não de bruxismo, baseou-se principalmente nos trabalhos de LAVIGNE, ROMPRÉ e MONTPLAISIR ${ }^{31}$, de 1996 e de MOLINA et al. ${ }^{43}$, de 1999.

O questionário desenvolvido e descrito por MOLINA et al. ${ }^{43}$, em 1999, foi aqui modificado de maneira a tornar-se mais sucinto. Para isso, algumas questões foram congregadas. Por exemplo, no questionário de MOLINA et al. ${ }^{43}$, existia uma questão para dor e outra para fadiga muscular ao acordar, porém, muitas vezes, torna-se complicado para o paciente diferenciar dor e fadiga, portanto tais questões tornaram-se uma única questão nesta pesquisa. Além disso, algumas questões do questionário de 1999 foram abolidas, como, por exemplo, a questão sobre sentir-se tenso durante o dia, uma vez que tal questão é muita ampla, podendo ou não, tal fato, estar relacionado com a presença de bruxismo e, portanto, sendo capaz de diagnosticar um maior número de falsos positivos.

Já o exame físico utilizado seguiu aquele descrito por LAVIGNE, ROMPRÉ e MONTPLAISIR ${ }^{31}$, de 1996, que validaram tal exame através de estudo controlado por polissonografia, no qual obtiveram altos índices de sensibilidade e especificidade para o exame físico quando comparados aos resultados 
polissonográficos, tornando esse exame físico altamente confiável para diagnóstico de bruxismo.

Os principais critérios avaliados no exame físico são a presença de facetas de desgaste coincidentes ou pontos brilhantes nas restaurações, provavelmente provenientes do hábito de apertar ou ranger os dentes, e a hipertrofia do músculo masséter.

Em 1969, AHLGREN et al. ${ }^{2}$, confirmaram a conexão entre hipertrofia do masséter e bruxismo, inferindo que o músculo apresenta-se hipertrófico devido ao excesso de exercícios decorrente do apertamento e ranger de dentes.

Sobre o exame de bruxismo, a opção por utilizar três examinadores calibrados para tal exame deu-se pelo fato de que para assegurar a confiabilidade dos dados coletados, a padronização do exame é essencial, sendo a calibração inter-examinadores uma das maneiras de se obter essa uniformidade nos procedimentos (SANTOS, 2000) $)^{52}$.

\subsection{Resultados obtidos}

Diversos são os estudos em que se avalia a influência do gênero ou do bruxismo na força máxima de mordida $2,8,13,15,19,20,21,25,26,28,32,33,34,36,38,40,41,50$, 54, 55, 60 e 61 . A grande diversidade na composição da amostra, idade de indivíduos e metodologias empregadas, no entanto, ainda não permitem conclusões muito convincentes, principalmente se o bruxismo é capaz de alterar a força de mordida pelo fortalecimento muscular. Assim sendo, tais forças poderiam exercer papel importante no diagnóstico dos distúrbios que afetam o sistema estomatognático $\left(\right.$ PELIZZER e MUENCH, 1997) ${ }^{48}$. 
Quanto ao gênero, existem controvérsias sobre as diferenças entre homens e mulheres (WALTIMO e KONONEN, 1993) ${ }^{60}$.

Assim como foi encontrado no presente trabalho, alguns estudos ${ }^{8,13,19,25}$, 28, 34, 38, 40, 41, 60 e 61 encontraram o gênero masculino como sendo capaz de exercer uma força máxima de mordida com valores superiores ao gênero feminino. Porém, em outros estudos $21,26,32,33,50,54,55$ e 60 isso não foi encontrado.

Nesse aspecto é importante observar fatores que possam, juntamente com o gênero, influenciar os resultados obtidos, como a idade dos indivíduos e os dentes envolvidos no registro de força (KILLIARIDIS et al., 1993) ${ }^{25}$.

É comum, em pesquisas envolvendo exclusivamente crianças, como a de LINDERHOLM et al. $^{33}$ de 1971 e a de SONNESEN, BAKKE e SOLOW ${ }^{54}$ e 55 , em 2001, não se encontrar diferenças significantes entre os valores de força máxima de mordida, uma vez que a força varia com a estrutura corporal e com a força muscular (LINDERHOLM et al. de 1971) ${ }^{33}$. Nas crianças, essas variáveis não apresentam tanta variação entre os gêneros como acontece com os adultos.

No trabalho de WALIMO e KONONEN $^{60}$ de 1993, foram relatadas diferenças significantes nos valores de força máxima de mordida entre os gêneros, apenas para os dentes posteriores, o que pode ser explicado pelo fato de a força máxima de mordida, na região anterior, ser limitada pela sensibilidade dentária e ligamentar, e não pela diferença na potência muscular, como acontece na região posterior. Isso pode explicar os resultados encontrados no trabalho de RAADSHEER et al. ${ }^{50}$, em 1999, em que a força de mordida foi avaliada apenas na região de canino, e os autores não encontraram diferença significante entre os gêneros. 
Nas outras pesquisas em que essa similaridade entre as forças de mordida de homens e mulheres foi encontrada, é cabível apontar como possíveis causas o reduzido número da amostra (KILLIARIDIS et al., 1995) ${ }^{26}$, ou a distribuição desigual de indivíduos por gênero (LINDERHOLM e WENNSTROM, 1970;

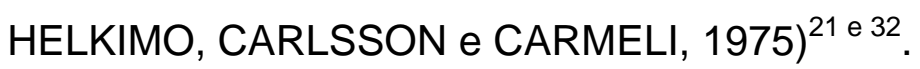

Porém, LINDERHOLM e WENNSTROM ${ }^{32}$, em 1970, explicam essa similaridade, afirmando que os hábitos mastigatórios de uma população podem influenciar mais sua força de mordida que suas dimensões corporais. Isso, segundo os autores, poderia explicar a proximidade entre os valores de força máxima de mordida dos indivíduos de ambos os gêneros, pois dieta e hábitos mastigatórios da população estudada eram similares.

Por outro lado, os autores que encontraram valores de força máxima de mordida maiores para o gênero masculino mencionam, na maioria das vezes, o fator muscular como responsável por tal achado.

WALTIMO e KONONEN ${ }^{60}$ e 61, em 1993 e em 1995 e MIURA et al. ${ }^{40}$, em 2001, acreditam que o gênero masculino apresenta maior força máxima de mordida devido à maior força muscular. Outros autores que justificaram esse fato foram HATCH et al. ${ }^{19}$, em 2001, que explicaram a diferença entre gêneros pela maior massa muscular dos músculos mastigatórios, característica do gênero masculino.

Seguindo esse pensamento, e baseando-se no fato de que os homens possuem maior força, potencial e massa musculares, é interessante observar alguns resultados encontrados na literatura. 
Em 1992, BAKKE et al. ${ }^{7}$ encontraram correlação positiva entre a espessura do músculo masséter e o valor de força de mordida dos indivíduos.

Sete anos mais tarde, em 1999, RAADSHEER et al. ${ }^{50}$ avaliaram a contribuição do tamanho dos músculos masséter, temporal e digástrico anterior na força máxima de mordida, e encontraram que a espessura do masséter mostrou relação significante com a magnitude da força de mordida.

Estes aspectos talvez expliquem os motivos pelos quais os homens, neste trabalho, apresentaram valores de força máxima de mordida significantemente maiores que os das mulheres, uma vez que, apresentando, os homens, maior massa e potencial muscular, poderia resultar em maior espessura do músculo masséter, que, por sua vez, pode ter como consequência uma maior força de mordida.

Quando se discutiu a força de mordida entre os gêneros, a principal justificativa apontada para que o gênero masculino apresentasse força máxima de mordida com valor significantemente maior que o feminino, foi o fato de que os homens possuem maior força, potencial e massa musculares, sendo tal afirmação fortalecida pelos resultados encontrados nos trabalhos de BAKKE et al. ${ }^{7}$, em 1992 e RAADSHEER et al. ${ }^{50}$, em 1999, onde os autores encontraram uma correlação positiva entre a espessura do músculo masséter e a força máxima de mordida dos indivíduos.

Quando se buscou associação entre força de mordida e bruxismo, não se encontrou nesta pesquisa, assim como observado por outros autores ${ }^{20,34}$ e 36 , diferença estatisticamente significante entre indivíduos portadores ou não de bruxismo, independente do gênero, para a força máxima de mordida. Porém, em 
outras pesquisas, foi notado que os indivíduos bruxômanos foram capazes de executar força máxima de mordida significantemente maior que os indivíduos não portadores de bruxismo $2,15,20,38$.

Tem sido relatado que indivíduos que realizam hábitos de apertamento e bruxismo noturno podem apresentar diversas manifestações, como desgaste dental, doenças periodontais e DTM ${ }^{6}$ e 10 devidas aos esforços resultantes desses hábitos.

NUNES ${ }^{45}$, em sua dissertação de mestrado, em 2003, buscou associação entre bruxismo do sono e DTM e encontrou que indivíduos portadores de DTM estão mais sujeitos a sentir dor após a realização de atividade parafuncional (bruxismo) do que os indivíduos controle, o que poderia indicar que os bruxômanos sem dor seriam mais resistentes à fadiga e ao dano, ou que a presença de algum processo patológico (DTM) seria necessária para que a atividade parafuncional (bruxismo) atuasse desencadeando ou agravando a sintomatologia.

Ainda, a autora ${ }^{45}$ levanta a hipótese de que, em alguns pacientes, a dor exerça um papel modulador na atividade parafuncional, com isso, reduzindo a amplitude e a velocidade de movimentos, além da atividade eletromiográfica dos músculos mastigatórios.

Além disso, LAVIGNE, ROMPRÉ e MONTPLAISIR ${ }^{31}$, em 1996, verificaram que os bruxômanos com dor realizam menor atividade motora.

Porém, quando a sintomatologia não se manifesta, os efeitos do hábito manifestam-se por meio de desgaste dental (bruxismo) ou hipertrofia muscular. 
Patologias de origem dentária (pulpites, abfrações) também podem estar associadas a hábitos parafuncionais.

Desde que aqueles com DTM moderada e severa foram excluídos da amostra, seria esperado que os indivíduos do grupo de bruxismo apresentassem, além do desgaste dentário (um dos fatores avaliados no exame físico de bruxismo), um maior desenvolvimento muscular.

Assim, poderia ser esperada uma maior força máxima de mordida para tais indivíduos, o que não ocorreu.

Em 1996, DEL FABBRO ${ }^{12}$, acompanhou o curso clínico de um paciente bruxômano para observar a flutuação desse distúrbio, através de polissonografia por 30 dias consecutivos, e encontrou que todas as variáveis relacionadas ao bruxismo variaram no decorrer dos 30 dias.

Ainda, a autora ${ }^{12}$ observou que há uma relação direta entre quantidade, intensidade e duração dos episódios de bruxismo. Assim, nas noites com mais episódios, esses também apresentam maior intensidade e duração, o que torna o hábito mais ou menos danoso ao sistema nos diferentes dias.

Os registros polissonográficos mostraram, portanto, que a freqüência e magnitude do bruxismo são muito variáveis durante as noites. Assim, existem períodos em que o indivíduo apresenta vários eventos de bruxismo por noite, enquanto pouca atividade é notada em outras noites.

Essa variação poderia explicar o resultado aqui obtido. Mensurações de força de mordida realizadas em período de bruxismo ativo poderiam estar influenciadas por fadiga muscular pós- exercícios, diminuindo os valores. Afinal, como foi verificado por LAVIGNE, ROMPRÉ e MONTPLAISIR ${ }^{31}$, em 1996, os 
bruxômanos com dor realizam menor atividade motora, portanto, nesses períodos, os indivíduos poderiam apresentar uma capacidade de executar força de mordida reduzida pela sintomatologia.

Tal afirmação, no entanto, só poderia ser confirmada com polissonografia, não utilizada nesta pesquisa.

AHLGREN et al. $^{2}$ e LYONS e BAXENDALE ${ }^{36}$, sugeriram que os hábitos de apertar e ranger os dentes podem beneficiar os músculos elevadores da mandíbula tornando-os mais fortes e, possivelmente, mais resistentes à fadiga.

Ainda, KILLIARIDIS et al. ${ }^{26}$, em 1995 afirmaram que o aumento da função dos músculos mastigatórios, através de treinamento, devido à parafunção ou a uma maior tolerância do mecanismo de controle da contração dos músculos mastigatórios, poderia contribuir para o aumento da força de mordida.

Em 1978, HELKIMO e INGERVALL ${ }^{20}$, também estudaram a associação entre a força de mordida e os hábitos parafuncionais de apertar e ranger os dentes. Os autores mensuraram a força máxima de mordida dos indivíduos entre os primeiros molares e incisivos e encontraram que os indivíduos com hábitos de apertar ou ranger os dentes tiveram maior força de mordida na região de incisivos, mas não na região de molares. Tal resultado foi justificado, pelos autores, pelo fato de que os hábitos são normalmente realizados em posições excêntricas, exercitando os músculos exigidos nessas posições (que acontece quando se mede a força de mordida em regiões anteriores) e não em uma posição cêntrica (que acontece quando se mensura a força em regiões posteriores). 
Portanto, esses achados justificam os resultados obtidos nas pesquisas que relacionaram bruxismo e força máxima de mordida, como os resultados obtidos nesta pesquisa e na de LINDQVIST e RINGQVIST ${ }^{34}$, em 1973, em que a força mordida foi mensurada na região de primeiros molares, e os resultados obtidos não demonstraram diferenças entre bruxômanos e não bruxômanos.

LYONS e BAXENDALE ${ }^{36}$, em 1990, não encontraram diferença significante entre os valores de força máxima de mordida para indivíduos com e sem bruxismo, avaliando esse fator na região de canino. Os autores apontaram a dificuldade de se realizar as mensurações em posições excêntricas (pela dificuldade de se atingir o mesmo grau de excentricidade), como um fator adverso de sua pesquisa. Contudo, alguns fatores intrínsecos à amostra selecionada podem justificar esses resultados. Por exemplo, uma amostra de 10 indivíduos, é uma amostra, indiscutivelmente, reduzida para uma pesquisa com esse objetivo. Além disso, os indivíduos selecionados apresentavam-se, segundo os autores, parcialmente dentados, o que parece ser outra desvantagem metodológica, como demonstrado por MIYAURA et al. ${ }^{41}$, em 1999. Nesse estudo da relação entre o número de dentes e a força de mordida, os autores encontraram que a mesma aumenta com o número de dentes presentes, sendo que indivíduos com 28 dentes são capazes de executar força de mordida com valores até duas vezes maiores que indivíduos com 22 ou 23 dentes.

Isso torna os resultados encontrados por LYONS e BAXENDALE ${ }^{36}$, em 1990, duvidosos, pois os autores, ao descreverem os indivíduos como parcialmente dentados, não utilizaram nenhum tipo de critério de exclusão que pudesse limitar o número máximo de dentes ausentes. 
Já GIBBS et al. ${ }^{15}$, em 1986 avaliaram a força máxima de mordida de indivíduos portadores ou não de bruxismo, na região posterior, e encontraram valores de força de mordida maiores para pacientes bruxômanos que para indivíduos controle. Nessa pesquisa não fica claro o número de indivíduos bruxômanos que foram avaliados. Os autores apenas citam quais foram os dois maiores valores de força encontrados. Além disso, esses valores são comparados aos de indivíduos controle examinados em pesquisas anteriores. Tais fatores dificultam a avaliação dos resultados, uma vez que não se sabe ao certo o tamanho da amostra, a distribuição entre os gêneros, idade, entre outros fatores não descritos.

Ainda nessa pesquisa, foi utilizado um gnatodinamômetro bilateral, apontado por TORTOPIDIS et al. ${ }^{58}$, em 1998, como sendo um aparato que produz maior variabilidade nos valores de força de mordida, além de ocasionar maior desconforto para os indivíduos estudados. Esse achado, somado aos problemas metodológicos encontrados na pesquisa de GIBBS et al. ${ }^{15}$, indica que os resultados encontrados pelos autores devem ser avaliados com cautela.

Com isso, justificam-se os resultados desta pesquisa, quanto à ausência de relação da força máxima de mordida e presença de bruxismo, através do fato de a força de mordida ter sido mensurada na região de primeiro molar, região onde a posição da mandíbula encontra-se próxima a uma posição cêntrica durante a mensuração.

Nessa região, os músculos mastigatórios não são excessivamente exercitados durante parafunção, resultando, portanto, em valores, de força máxima de mordida, semelhantes para indivíduos portadores ou não de bruxismo. 
Além disso, os resultados também podem ser justificados pelo fato de que a mensuração pode ter ocorrido em período de bruxismo ativo, o que poderia resultar em valores reduzidos, devido a uma possível fadiga muscular.

Baseado nisso, conclui-se que a força de mordida não deve ser usada como parâmetro para detecção de bruxômanos.

Sobre a concordância inter-examinadores, uma concordância ótima entre os examinadores foi encontrada. Tal fato mostra que os examinadores apresentaram, entre si, um alto índice de coincidência de diagnóstico, fortalecendo a credibilidade da divisão dos grupos entre controle e experimental.

Na pesquisa de NUNES ${ }^{45}$, em 2003, a autora utilizou o mesmo exame de bruxismo que o utilizado nesta pesquisa, porém, seus examinadores não foram calibrados para o exame físico. Os valores de Kappa encontrados, em sua pesquisa, representaram concordância considerável ou moderada entre seus examinadores.

Tal fato demonstra a necessidade de os examinadores serem calibrados, fortalecendo a afirmação de $\operatorname{SANTOS}^{52}$, em 2000, que afirmou que para assegurar a confiabilidade dos dados coletados, a padronização do exame é essencial, sendo a calibração inter-examinadores uma das maneiras de se obter essa uniformidade nos procedimentos.

Tendo sido o exame físico aqui utilizado validado por LAVIGNE, ROMPRÉ e MONTPLAISIR ${ }^{31}$, em 1996, através de comparação com polissonografia, e obtido altos graus de concordância no presente trabalho, pode-se concluir que com o treinamento profissional, tal exame pode ser aplicado para um diagnóstico confiável de presença de bruxismo. 
7. CONCLUSÕES 


\section{CONCLUSÕES}

Considerando-se a amostra utilizada e a metodologia empregada neste estudo, pôde-se chegar às seguintes conclusões:

1. O gênero do indivíduo parece exercer influência em sua força máxima de mordida, sendo que, independentemente do grupo, o gênero masculino apresentou força máxima maior que o gênero feminino.

2. A presença de bruxismo não demonstrou nenhuma influência nos valores de força máxima de mordida dos indivíduos desta pesquisa.

3. Dentre os hábitos parafuncionais avaliados neste estudo, apenas o hábito de mascar chiclete demonstrou uma associação com o gênero feminino.

4. A concordância inter-examinadores para o exame físico de bruxismo foi considerada ótima entre os 3 examinadores desta pesquisa. 
ANEXOS 


\title{
ANEXO 1- Comitê de Ética em Pesquisa
}

\author{
Universidade de São Paulo \\ Faculdade de Odontologia de Bauru \\ A1. Dr. Octávio Pinheiro Brisolla, 9-75 - Bauru-SP - CEP 17012-901 - C.P. 73 \\ PABX (0XX14)235-8000 - FAX (0XX14)223-4679 \\ Comitê de Ética em Pesquisa
}

Processo $n^{o} 146 / 2002$

Bauru, 13 de fevereiro de 2003

Senhor Professor,

Informamos que após o envio da documentação pendente, o projeto de pesquisa encaminhado a este Comitê denominado "Avaliação da influência do gênero na força de mordida em pacientes portadores de bruxismo", de autoria de Patrícia dos Santos Calderon, que será desenvolvido sob sua orientação, foi APROVADO.

Comunicamos que após o envio do trabalho concluído, este Comitê enviará o parecer final, que será utilizado para a publicação do trabalho.

Atenciosamente,

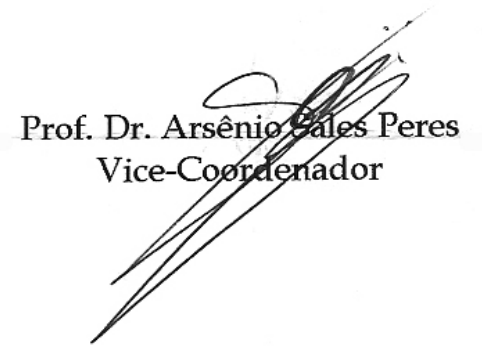

Ilm $^{\circ}$ Sr. Prof. Dr. Paulo César Rodrigues Conti

DD. Docente do Departamento de Prótese 


\section{Universidade de São Paulo Faculdade de Odontologia de Bauru \\ Al Dr. Octávio Pinheiro Brisolla, 9-75 - Bauru-SP-CEP 17012-901 - C.P. 73 PABX (0XX14)3235-8000 - FAX (0XX14)3223-4679 \\ Comitê dé Ética em Pesquisa (3235-8356)}

Processo $n^{\circ} 146 / 2002$

Bauru, 28 de janeiro de 2004.

Senhor Professor,

Informamos que após análise por este Comitê de Ética em Pesquisa em Seres Humanos, a alteração do título do projeto de pesquisa intitulado "Avaliação da influência do gênero na força da mordida em pacientes portadores de bruxismo" de autoria da C.D. Patrícia dos Santos Calderon, desenvolvido sob sua orientação, para "Avaliação da influência do bruxismo e do gênero na força máxima de mordida dos indivíduos foi aprovado considerando que não houve modificação em sua metodologia.

Lembramos que após o envio do trabalho concluido, este Comitê enviará o parecer final, que será utilizado para a publicação do trabalho.

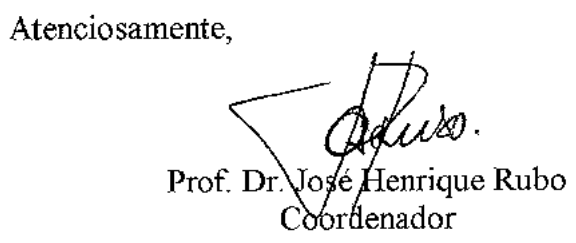

$\mathrm{Ilm}^{\circ}$ Sr. Prof. Dr. Paulo César Rodrigues Conti

DD. Docente do Departamento de Prótese 


\title{
ANEXO 2- Carta de informação ao paciente
}

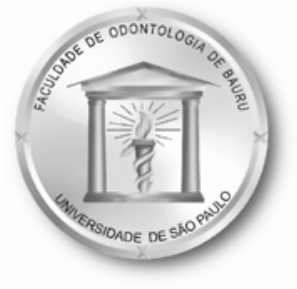

\author{
UNIVERSIDADE DE SÃO PAULO
}

FACULDADE DE ODONTOLOGIA DE BAURU

Al. Dr. Octávio Pinheiro Brisolla, 9-75 - Bauru-SP - CEP 17012-901 - C.P. 73

PABX (0XX14)235-8000 - FAX (0XX14)223-4679

\section{CARTA DE INFORMAÇÃO AO PACIENTE}

O senhor(a) estará participando de uma pesquisa chamada "AVALIAÇÃo DA INFLUÊNCIA DO GÊNERO NA FORÇA DE MORDIDA EM PACIENTES PORTADORES DE BRUXISMO", que tem como objetivo medir a força de mordida dos pacientes com e sem bruxismo (ranger dos dentes), e depois compará-las entre si e entre os gêneros, e com isso saberemos se o bruxismo e o gênero têm alguma influência sobre a força máxima de mordida dos pacientes.

Para isso utilizaremos um aparelho chamado gnatodinamômetro, onde o senhor(a) deverá morder com sua máxima força uma haste metálica, protegida para evitar contaminação, que vai medir sua força de mordida. Isso será repetido três vezes na primeira sessão, e mais três vezes uma semana depois.

Esse procedimento é rápido, porém pode causar um certo desconforto pela presença da haste na sua boca.

Durante o registro dessa força, o que é bastante rápido, pode haver uma leve sensibilidade nos músculos ou juntas da face, porém esses riscos são pequenos, uma vez que, todo o procedimento será feito sob supervisão de profissionais. Caso ocorra algum tipo de dano, diretamente causado pela pesquisa, o senhor(a) terá disponibilidade de tratamento médico e a indenização a que legalmente teria direito, por parte da Instituição.

Os pacientes portadores de bruxismo serão orientados ou encaminhados para tratamento.

O senhor(a) tem a garantia de receber respostas a qualquer pergunta ou esclarecimento a qualquer dúvida sobre os procedimentos, riscos, benefícios e outros assuntos relacionados com a pesquisa Além disso, tem a liberdade de retirar seu consentimento a qualquer momento e deixar de participar no estudo, sem qualquer prejuízo à continuidade de quaisquer tratamentos que estejam sendo realizados nessa Instituição.

Não há necessidade de o senhor(a) se identificar, e as informações fornecidas serão mantidas confidenciais, respeitando sua privacidade.

Se existirem gastos adicionais, estes serão absorvidos pelo orçamento da pesquisa. 
ANEXO 3- Termo de consentimento livre e esclarecido

\author{
UNIVERSIDADE DE SÃO PAULO
}

FACULDADE DE ODONTOLOGIA DE BAURU

Al. Dr. Octávio Pinheiro Brisolla, 9-75 - Bauru-SP - CEP 17012-901 - C.P. 73

PABX (0XX14)235-8000 - FAX (0XX14)223-4679

\title{
TERMO DE CONSENTIMENTO LIVRE E ESCLARECIDO
}

Pelo presente instrumento que atende às exigências legais, o Sr. (a)

portador da cédula de identidade , após leitura

minuciosa da CARTA DE INFORMAÇÃO AO PACIENTE, devidamente explicada pelos profissionais em seus mínimos detalhes, ciente dos serviços e procedimentos aos quais será submetido, não restando quaisquer dúvidas a respeito do lido e explicado, firma seu CONSENTIMENTO LIVRE E ESCLARECIDO concordando em participar da pesquisa proposta.

Fica claro que o paciente ou seu representante legal, pode a qualquer momento retirar seu CONSENTIMENTO LIVRE E ESCLARECIDO e deixar de participar desta pesquisa e ciente de que todas as informações prestadas tornaram-se confidenciais e guardadas por força de sigilo profissional (Art. $9^{\circ}$ do Código de Ética Odontológica).

Por estarem de acordo assinam o presente termo.

Bauru-SP, de de 


\section{ANEXO 4- Ficha de exame inicial}

\section{AVALIAÇÃO DA INFLUÊNCIA DO GÊNERO NA FORÇA DE MORDIDA EM PACIENTES PORTADORES DE BRUXISMO}

Mestranda: Patrícia dos Santos Calderon Orientador: Prof. Dr. Paulo César Rodrigues Conti

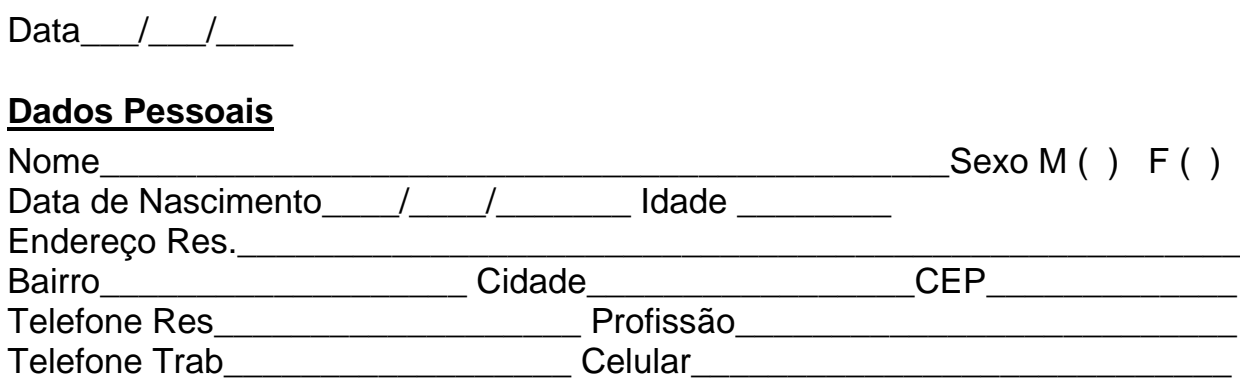

\section{Questionário Geral}

\section{Você teve ou tem algum dos problemas abaixo?}

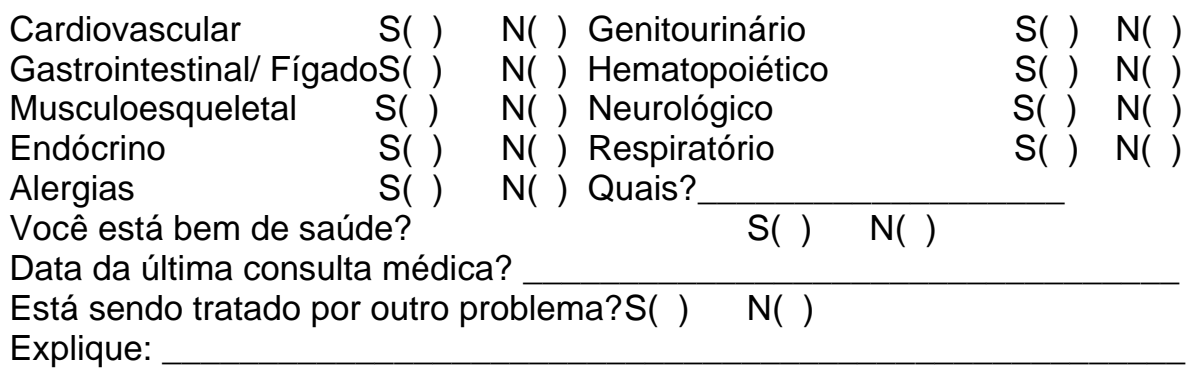

Hábitos parafuncionais

$\begin{array}{lllll}\text { Ranger os dentes } & \mathrm{S}(\text { ) } & \mathrm{N}(\text { ) Mascar chicletes } & \mathrm{S}(\text { ) } & \mathrm{N}(\text { ) } \\ \text { Apertamento } & \mathrm{S}(\text { ) } & \mathrm{N}(\text { ) Uso contínuo do telefone } & \mathrm{S}(\text { ) } & \mathrm{N}(\text { ) } \\ \text { Morder unhas } & \mathrm{S}(\text { ) } & \mathrm{N}(\text { ) Uso contínuo do computador } & \mathrm{S}(\text { ) } & \mathrm{N}(\text { ) }\end{array}$

\section{$\underline{\text { Avaliação dentária e oclusal }}$}

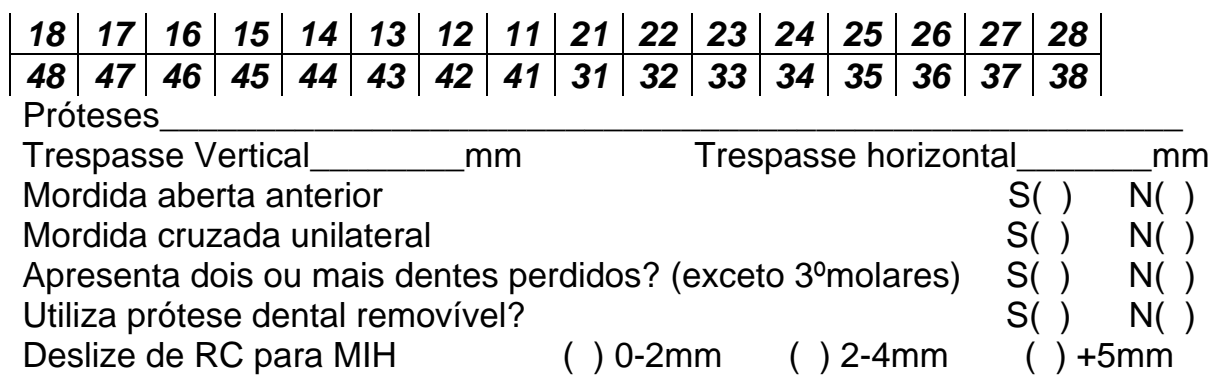




\section{ANEXO 5- Questionário de DTM}

\section{Questionário de DTM}

0 a 3: não portador de DTM

4 a 8: portador de DTM leve

9 a 14: portador de DTM moderada

15 a 23: portador de DTM severa

\begin{tabular}{|l|l|l|l|}
\hline & SIM & NÃO & ÀS VEZES \\
\hline 1. Você sente dificuldade de abrir a boca? & & & \\
\hline 2. Você sente dificuldade de movimentar sua mandíbula para os lados? & & & \\
\hline 3. Você sente desconforto ou dor muscular quando mastiga? & & & \\
\hline 4. Você sente dores de cabeça com frequência? & & & \\
\hline 5. Você sente dores no pescoço e/ou ombros? & & & \\
\hline 6. Você sente dores de ouvido ou próximo a ele? & & & \\
\hline 7. Você percebe algum ruído na ATM? & & & \\
\hline 8. Você considera sua mordida "anormal"? & & & \\
\hline 9. Você usa apenas um lado de sua boca para mastigar? & & & \\
\hline 10. Você sente dores na face ao acordar? & & \\
\hline
\end{tabular}




\section{ANEXO 6- Exame de bruxismo}

EXAMINADORES 1,2 e 3

\section{Questionário de bruxismo}

\begin{tabular}{|l|l|l|l|}
\hline & SIM & NÃO & ÀS VEZES \\
\hline Acorda durante a noite apertando ou rangendo os dentes & & & \\
\hline Tem fadiga ou dor nos músculos mastigatórios, ao acordar & & & \\
\hline Acorda durante a noite ou pela manhã com as ATMs travadas & & & \\
\hline Sente desconforto nos dentes ao acordar & & & \\
\hline $\begin{array}{l}\text { História nos últimos dois meses de deslocamento repetido de } \\
\text { restaurações definitivas }\end{array}$ & & & \\
\hline Alguém já relatou que você range os dentes dormindo & & & \\
\hline
\end{tabular}

\section{Exame físico de bruxismo}

Facetas coincidentes : SIM NÃO

Pontos brilhantes nas restaurações: SIM_ NÃO

Hipertrofia do masséter com palpação digital: SIM NÃO

Bruxômano ativo: SIM NÃO 
ANEXO 7- Ficha para arquivar valores de força de mordida

Obtenção dos registros

$1^{a}$ Consulta: Data:

\begin{tabular}{|c|c|}
\hline Registro & Força Máxima \\
\hline 1 & \\
\hline 2 & \\
\hline 3 & \\
\hline
\end{tabular}

$2^{\text {a }}$ Consulta: Data:

\begin{tabular}{|c|c|}
\hline Registro & Força Máxima \\
\hline 1 & \\
\hline 2 & \\
\hline 3 & \\
\hline
\end{tabular}


REFERÊNCIAS BIBLIOGRÁFICAS 


\section{REFERÊNCIAS BIBLIOGRÁFICAS*}

1. AGERBERG, G. Bite force after temporomandibular joint surgery. Int J Oral Maxillofac Surg, v.17, , n.3, p.177-80, June 1988.

2. AHLGREN, J. et al. Bruxism and hypertrophy of the masseter muscle: a clinical, morphological and functional investigation. Pract Oto-rhinolaryng, v. 31, p. 22-9, 1969.

3. AMERICAN ACADEMY OF OROFACIAL PAIN: Orofacial pain: guidelines for assessment, classification, and management. Chicago IL, Quintessence, 1996, p. 223-68 apud KATO, T. et al. Bruxism and orofacial movements during sleep. Dent Clin North Am, v.45, n.4, p. 657-85, Oct. 2001.

4. AMERICAN SLEEP DISORDERS ASSOCIATION (ASDA) Arousals scoring rules and examples: a preliminary report from sleep disorders atlas task force of American Sleep Disorders Association. Sleep, v.15, p.17384, 1992.

\footnotetext{
* Normas recomendadas para o uso no âmbito da Universidade de São Paulo, com base no documento “Referências Bibliográficas: exemplos”, emanado do Conselho Supervisor do Sistema Integrado de Bibliotecas da USP, em reunião de 20 de setembro de 1990.
} 
5. ARIMA, T.; ARENDT-NIELSEN, L.; SVENSSON, P. Effect of jaw muscle pain and soreness evoked by capsaicin before sleep on orofacial motor activity during sleep. J Orofac Pain, v.15, n.3, p.245-56, Summer 2001.

6. ATTANASIO, R. Nocturnal bruxism and its clinical management. Dent Clin North Am, v.35, n.1, p.245-252, Jan. 1991.

7. BAKKE, M. et al. Ultrasound image of human masseter muscle related to bite force, electromyography, facial morphology, and occlusal factors. Scand J Dent Res, v.100, n.3, p. 164-71, June 1992.

8. BRAUN, S. et al. A study of bite force, part 1: relationship to various physical characteristics. Angle Orthod, v.65, n.5, p.367-71, 1995.

9. CLARK, G. T., BEEMSTERBOER, P. L.; JACOBSON, R. The effect of sustained submaximal clenching on maximum bite force in myofascial pain dysfunction patients. J Oral Rehabil, v.11, n. 4, p.387-91, July 1984.

10. CLARK, G. T.; BEEMSTERBOER, P. L.; RUGH, J. D. Nocturnal masseter muscle activity and the symptoms of masticatory dysfunction. $\mathbf{J}$ Oral Rehabil, v.8, n.3, p.279-286, May 1981.

11.CONTI, A.C.C.F. Avaliação transversal da relação entre sinais e sintomas das disfunções temporomandibulares e o tratamento 
ortodôntico. Bauru, 2000. 130p. Dissertação (Mestrado) - Faculdade de Odontologia de Bauru, Universidade de São Paulo.

12. DAL FABBRO, C. Estudo linear de um paciente com bruxismo através de análise eletromiográfica do músculo masseter, avaliação polissonográfica e psicológica. Bauru, 1996. 181p. Dissertação (Mestrado) - Faculdade de Odontologia de Bauru, Universidade de São Paulo.

13. FERNANDES, C. P. et al. A novel sensor for bite force determinations. Dent Mat, v.19, n.2, p.118-26, Mar. 2003.

14. FIELDS, H. W. et al. Variables affecting measurements of vertical occlusal force. J Dent Res, v.65, n.2, p.135-8, Feb. 1986.

15. GIBBS, C. H. et al. Limits of human bite strength. J Prosthet Dent, v. 56, , n.2, p. 226-9, Aug. 1986.

16. GLAROS, A. Incidence of diurnal and nocturnal bruxism. J Prosthet Dent, v.45, n.5, p. 545-9, May 1981.

17.GOULET, J.P. et al. Daily clenching, nocturnal bruxism, and stress and their association with TMD symptoms. J Orofac Pain, v.7, p. 120, 1993. /Abstract/ 
18. HARALDSON, T., CALRSSON, G. E. Bite force and oral function in patients with osseointegrated oral implants. Scand J Dent Res, v.85, n.3, p. 200-8, Mar. 1977.

19. HATCH, J. P. et al. Determinants of masticatory performance in dentate adults. Arch Oral Biol, v.46, p.641-8, 2000.

20. HELKIMO, E.; INGERVALL, B. Bite force and functional state of the masticatory system in young men. Swed Dent J, v. 2, p. 167-75, 1978.

21. HELKIMO, E.; CARLSSON, G. E.; CARMELI, Y. Bite force and oral function in patients with disturbances of the manticatory system. J Oral Rehabil, v.2, p.397-406, 1975.

22. HELKIMO, E.; CARLSSON, G. E.; HELKIMO, M. Bite force and state of dentition. Acta Odontol Scand, v.35, p. 297-303, 1976.

23. KATO, T. et al. Bruxism and orofacial movements during sleep. Dent Clin North Am, v.45, n.4, p. 657-85, Oct. 2001.

24. KATO, T et al. Sleep bruxism: an oromotor activity secondary to microarousal. J Dent Res, v.80, n,10, p. 1940-4. Oct. 2001. 
25. KILIARIDIS, S. et al. The relationship between maximal bite force, bite force endurance, and facial morphology during growth: a cross-sectional study. Acta Odontol Scand, v.51, n.5, p.323-31, Oct. 1993.

26. KILLIARIDIS, S. et al. Craniofacial morphology, occlusal traits, and bite force in persons with advanced occlusal tooth wear. Am J Orthod Dentofac Orthop, v.107, n.3, p. 286-91, Mar.1995.

27. KLEINFELDER, J. W.; LUDWIG, K. Maximal bite force in patients with reduced periodontal tissue sopport with and without splinting. $\mathbf{J}$ Periodontol, v.73, n.10, p.1184-7, Oct. 2002.

28. KOVERO, O. et al. Maximal bite force and its association with spinal posture and craniofacial morphology in young adults. Acta Odontol Scand, v. 60, n. 6, p. 365-9, Dec. 2002.

29. LANDIS, J. R.; KOCH, G. G. The measurement of observer agreement for categorical data. Biometrics, v. 33, n.1, p.159-74, Mar. 1977.

30. LAVIGNE, G.J.; MONTPLAISIR, J.Y. Restless legs syndrome and sleep bruxism: prevalence and association among Canadians. Sleep, v.17, n.8, p. 739-43, Dec. 1994. 
31. LAVIGNE, G.J.; ROMPRÉ, P.H.; MONTPLAISIR, J.Y. Sleep bruxism: validity of clinical research diagnostic criteria in a controlled polysomnographic study. J Dent Res, v.75, n.1, p.546-52. Jan. 1996.

32. LINDERHOLM, H.; WENNSTRON, A. Isometric bite force and its relation to general muscle force and body build. Acta Odontol Scand, v.28, n.5, p. 679-89, Nov. 1970.

33. LINDERHOLM, $\mathrm{H}$. et al. Isometric bite force in children and its relation to body build and general muscle force. Acta Odontol Scand, v.29, n.5, p. 563-8, Nov. 1971.

34. LINDQVIST, B.; RINGQVIST, M. Bite force in children with bruxism. Acta Odontol Scand, v.31, n.4, p.255-9, 1973.

35. LOBBEZOO, F.; LAVIGNE, G.J. Do bruxism and temporomandibular disorders have a cause-and-effect relationship? J Orofac Pain, v. 11, n.1, p.15-23, Winter 1997.

36. LYONS, M. F.; BAXENDALE, R. H. A preliminary electromyographic study of bite force and jaw- closing muscle fatigue in human subjects with advanced tooth wear. J Oral Rehabil, v.17, n.4, p.311-8, July 1990. 
37. MANNS, A.; MIRALLES, R.; PALAZZI, C. EMG, bite force and elongation of the masseter muscle under isometric voluntary contractions and variations of vertical dimension. J Prosthet Dent, v. 42, n. 6, p. 674-82, 1979.

38. MANTYVAARA, J. et al. Altered control of submaximal bite force during bruxism in humans. Eur J Appl Physiol, v.79, n.4, p. 325-30, Mar. 1999.

39. MIGRAINE, D. et al. Bruxism and onychophagy in children: prevalence and relative risk factors [abstract 1610]. J Dent Res, v.75, p. 219, 1996. /Abstract 1610/

40. MIURA, $\mathrm{H}$. et al. Comparison of maximum bite force and dentate status between healthy and frail elderly persons. J Oral Rehabil, v. 28, n.1, p. 592-5, June 2001.

41. MIYAURA, K. et al. Comparison of biting forces in different age and sex groups: a study of biting efficiency with mobile and non-mobile teeth. $\mathbf{J}$ Oral Rehabil, v.26, n.3, p. 223-7, Mar. 1999.

42. MOLIN, C. Vertical isometric muscle forces of the mandible: a comparative study of subjects with and without manifest mandibular pain dysfunction syndrome. Acta Odontol Scand. v.30, n. 4, p.485-99, Oct. 1972. 
43. MOLINA, O.F. et al. A clinical study of specific signs and symptoms of CMD in bruxers classified by the degree of severity. Cranio, v.17, n.4, p. 268-79, Oct. 1999.

44. NISHIGAWA, K.; BANDO, E.; NAKANO, M. Quantitative study of bite force during sleep associated bruxism. J Oral Rehabil, v.28, n.1, p. 485-91, May 2001.

45. NUNES, L. M. O. Associação entre bruxismo do sono e disfunção temporomandibular. Bauru, 2003. 193p. Dissertação (Mestrado) Faculdade de Odontologia de Bauru, Universidade de São Paulo.

46. OW, R. K. K.; CARLSSON, G. F.; JEMT, T. Biting forces in patients with craniomandibular disorders. Cranio, v.7, n.2, p.119-25, Apr. 1989.

47. PAULA, L. V. Estudo longitudinal da força de mordida de indivíduos dentados e edentados reabilitados com próteses convencionais e implanto-suportadas. São Paulo, 1998. 100p. Tese (Doutorado) Faculdade de Odontologia da Universidade de São Paulo.

48. PELLIZER, E. P.; MUENCH, A. Forças de mordida relacionadas a próteses removíveis inferiores. São Paulo, 1997. 118p. Tese (Doutorado) - Faculdade de Odontologia da Universidade de São Paulo. 
49.PULLINGER, A.G.; SELIGMAN, D.A.; GORNBEIN, J.A. A multiple logistic regression analysis of the risk and relative odds of temporomandibular disorders as a function of common occlusal features. J Dent Res, v.72, n.6, p. 968-79 June 1993.

50. RAADSHEER, M. C. et al. Contribuition of jaw muscle size and craniofacial morphology to human bite force magnitude. J Dent Res, v.78, n.1, p. 3142, Jan. 1999.

51.RENTES, A. M.; GAVIÃO, M. B. D.; AMARAL J. R. Bite force determination in children with primary dentition. J Oral Rehabil, v.19, n.12, p. 1174-80, Dec. 2002.

52. SANTOS, C. N. Avaliação da reprodutibilidade interexaminadores na palpação muscular após um programa de calibração. Bauru, 2000. 124p. Dissertação (Mestrado) - Faculdade de Odontologia de Bauru, Universidade de São Paulo.

53. SINN, D. P.; ASSIS, E. A.; THROCKMORTON, G. S. Mandibular excursions and maximum bite forces in patients with temporomandibular joint disorders. J Oral Maxillofac Surg, v.54, n.6, p. 671-9, June 1996.

54.SONNESEN, L.; BAKKE, M.; SOLOW, B. Bite force pre-otthodontic children with unilateral crossbite. Eur J Orthod, v.23, p. 741-9, 2001. 
55. SONNESEN, L.; BAKKE, M.; SOLOW, B. Temporomandibular disorders in relation to cranifacial dimensions, head posture and bite force in children selected for orthodontic treatment. Eur J Orthod, v.23, p. 179-92, 2001.

56. STEGENGA, B.; BROEKHUIJSEN, M. L.; WILLIGEN, J. D. V. Clinical significance of bite force reproduction ability. J Craniomandib Disord, v. 4, n.1, p.8-16, Winter 1990.

57. THROCKMORTON, G. S.; ELLIS III, E. The relationship between surgical changes in dentofacial morphology and changes in maximum bite force. $\mathbf{J}$ Oral Maxillofac Surg, v.59, n.6, p.620-7, June 2001.

58. TORTOPIDIS, D. et al. The variability of bite force measurement between sessions, in different positions within the dental arch. J Oral Rehabil, v.25, n.2, p.681-6, Sept. 1998.

59. YOUNG, D. V. et al. The craniofacial morphology of bruxers versus nonbruxers. Angle Orthod, v.69, n.1, p. 14-8, Feb. 1999.

60. WALTIMO, A.; KONONEN, M. A novel bite force recorder and maximal isometric bite force values for healthy young adults. Scand J Dent Res, v.101, n.3, p. 171-5, June 1993. 
61. WALTIMO, A.; KONONEN, M. Maximal bite force and its association with signs and symptoms of craniomandibular disorder in young Finnish nonpatients. Acta Odontol Scand, v.53, n.4, p.254-8, Aug. 1995.

62. WILDMALM, S.E.; CHRISTIANSEN, R.L.; GUNN, S.M. Oral parafunctions as temporomandibular disorder risk factors in children. J Craniomand Pract, v. 13, n.4, p. 242-6, Oct. 1995. 
ABSTRACT 


\section{ABSTRACT}

The objective of this research was to evaluate the influence of gender and bruxism in the maximum bite force. The concordance for the physical examination of bruxism between the examiners was evaluated as well. One hundred and twenty individuals, from both genders, bruxists and non bruxists, with mean age of 20.46 years old, were selected for the research. For the group establishment, every individual was submitted to inclusion and exclusion criteria, and to a specific physical examination for bruxism (performed by three different examiners). After that, the maximum bite force of every individual was measured using a gnatodinamometer at the first molar site, three times on each side, at two different times, separated by an average period of ten days. The highest measurement found among the six readings on each side was recorded. The data were then statistically analyzed using a two-way ANOVA, with a level of significance of $5 \%$. For the concordance between examiners the Kappa statistical test was applied. The maximum bite force values were statistically higher for males $(p=0.00)$, independently from the group analyzed. No statistically difference on the maximum bite force was observed from the gender $(p=0.25)$. Finally, the concordance between examiners for physical examination of bruxism was considered optimal between the examiners. Based on these results, the authors can conclude that the bite force shall not be used as parameter for diagnosis of bruxism. 